HYDROGEOLOGY AND WATER QUALITY OF AREAS WITH PERSISTENT GROUND-WATER CONTAMINATION NEAR BLACKFOOT, BINGHAM COUNTY, IDAHO

By D.J. Parliman

U.S. GEOLOGICAL SURVEY

Water-Resources Investigations Report 87-4150

Prepared in cooperation with the IDAHO DEPARTMENT OF HEALTH AND WELFARE, Division of Environment

Boise, Idaho 


\author{
DEPARTMENT OF THE INTERIOR \\ DONALD PAUL HODEL, Secretary \\ U.S. GEOLOGICAL SURVEY \\ Dallas L. Peck, Director
}

For additional information, write to:

Acting District Chief U.S. Geological Survey, WRD 230 Collins Road Boise, ID 83702 (208) 334-1750
Copies of this report may be purchased from:

U.S. Geological Survey

Books and Open-File Reports

Federal Center, Bldg. 810

Box 25425

Denver, CO 80225

(303) 236-7476 


\title{
HYDROGEOLOGY AND WATER QUALITY OF AREAS WITH PERSISTENT GROUND-WATER CONTAMINATION NEAR BLACKFOOT, BINGHAM COUNTY, IDAHO
}

\author{
U.S. GEOLOGICAL SURVEY
}

Water-Resources Investigations Report 87-4150

Prepared in cooperation with the IDAHO DEPARTMENT OF HEALTH AND WELFARE. Division of Environment
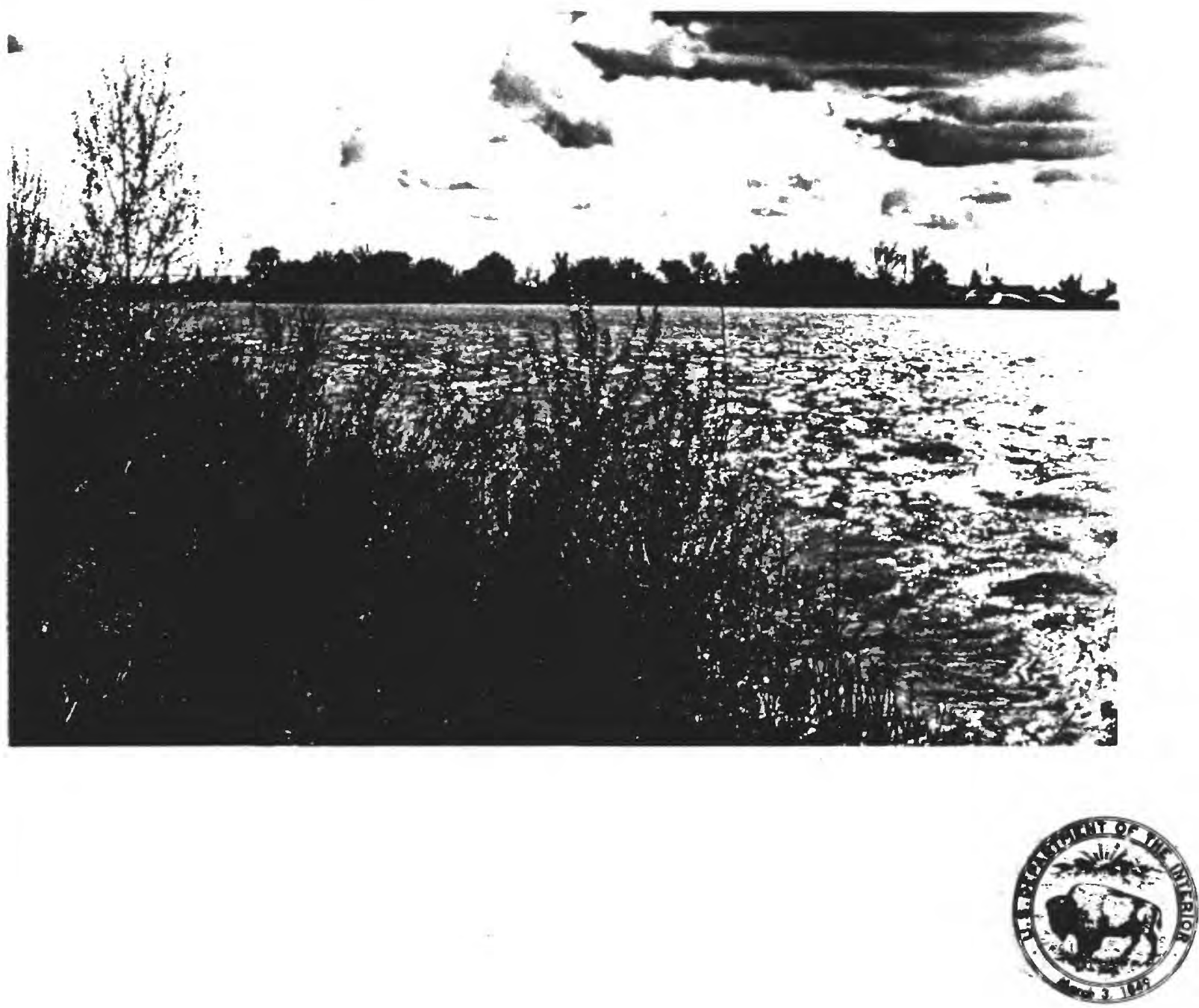
Abstract................................ I

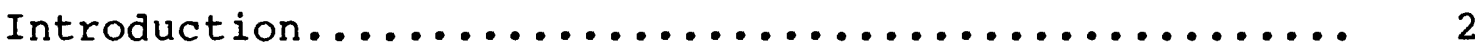

Purpose and scope......................... 4

Methods................................. 5

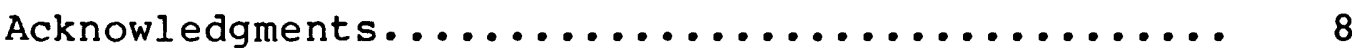

Description of the study area.................... 9

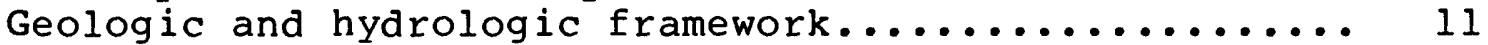

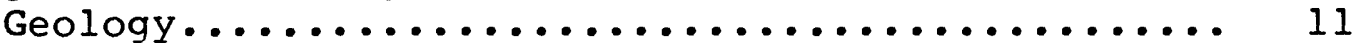

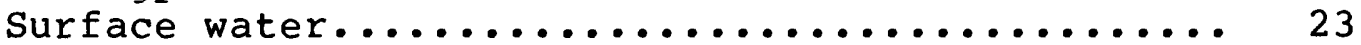

Movement of water through unsaturated rock...... 27

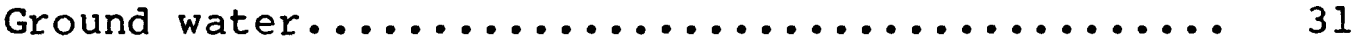

Ground-water quality in the Groveland-Collins area,

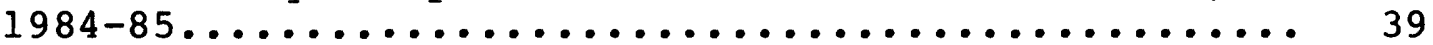

Temporal variation in water-quality charac-

teristics........................... 39

Suitability of water for use................ 43

water-quality data...................... 47

Cations and anions.................. 47

Dissolved solids and specific

conductance..................... 60

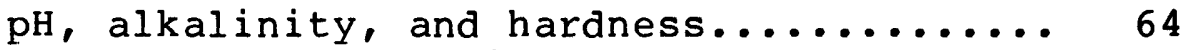

Nutrients and organic carbon............ 66

Dissolved oxygen, iron, manganese, and

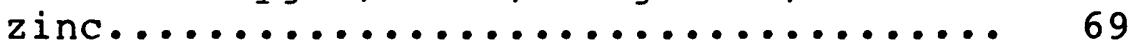

Gasoline, selected trace elements, pesticides, and stable isotopes....... 73

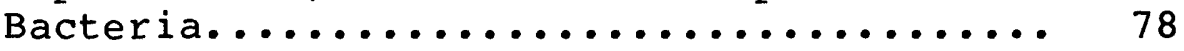

Locations and probable sources of groundwater contamination..................... 80

Relation of well structure and construction to ground-water contamination................... 80

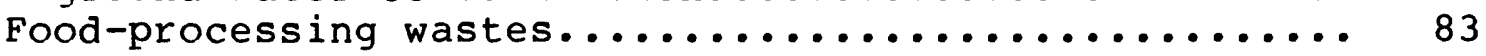

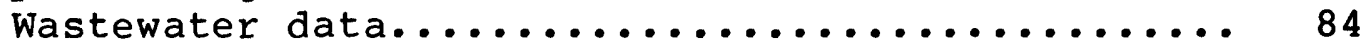

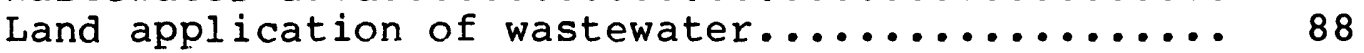

Development of a ground-water model and further

studies................................. 92

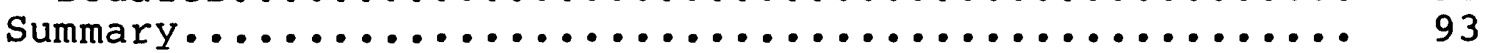

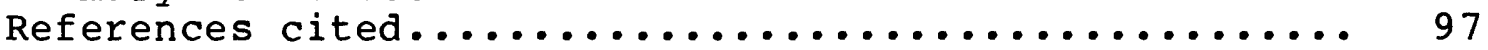


Page

Figures 1-7F. Maps showing:

1. Location of Groveland-Collins and

surrounding areas.............

2. Location and identification of wells in Groveland-Collins and

surrounding areas, 1984-85...... 102

3. Location and identification of

wells with water-quality data,

Groveland-Collins and surround-

ing areas, pre-1984 and 1984-85.. 7

4. Selected land-use features........ 12

5. Generalized surficial geology...... 13

6. Structural contours of the basalt surface.................. 16

7A. Locations of selected wells and comparison of well data........ 17

7B-7F. Diagrams showing lithology, well construction, and range of water levels:

7B. Section $A-A^{\prime} \ldots \ldots \ldots \ldots \ldots \ldots \ldots$

7C. Section $B-B^{\prime} \ldots \ldots \ldots \ldots \ldots \ldots \ldots \ldots$

7D. Section $B^{\prime}-B^{\prime}$............. 20

7E. Section $C-C^{\prime} \ldots \ldots \ldots \ldots \ldots \ldots \ldots \ldots 21$

7F. Section D-D'.............. 22

8. Map showing approximate locations of pre-1960 and 1985 channels of the Snake River................... 25

9. Diagrams showing water-surface altitudes of the Snake River at Blackfoot and total monthly precipitation at Blackfoot, October 1983 to September $1985 \ldots \ldots \ldots \ldots \ldots . \ldots \ldots$

10. Map showing locations of selected canals, ditches, and sloughs....... 28

11. Diagram showing idealized paths of water movement in unsaturated and saturated rock................ 29

12. Maps showing water-level contours and generalized direction of ground-water movement, Groveland-Collins and surrounding areas, January to November

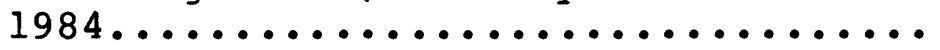

13. Map showing water-level contours and generalized direction of ground-water movement, Groveland-Collins area, January to September 1985.......... 
Page

Figure 14A. Hydrographs of selected wells near

the Snake River, Groveland, or

Collins, $1984-85 \ldots \ldots \ldots \ldots \ldots \ldots \ldots .35$

14B. Hydrographs of selected wells near

Collins, $1984-85 \ldots \ldots \ldots \ldots \ldots \ldots \ldots . .36$

15A-17. Diagrams showing:

15A. Relations of water-level fluctuations to well construction and subsurface rock, 1984-85... 40

15B. Relations of water-level altitudes to basalt surface and period of saturated sediment,

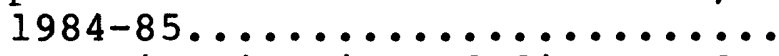

16A. Areal distribution of dissolved potassium, specific conductance, and bicarbonate, May

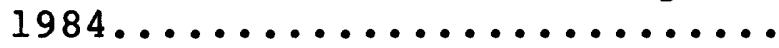

16B. Areal distribution of dissolved nitrite plus nitrate (as nitrogen), ammonia plus organic nitrogen, organic carbon, and oxygen, May 1984............

16C. Areal distribution of dissolved iron, manganese, and zinc, May $1984 \ldots \ldots \ldots \ldots \ldots \ldots \ldots$

17. Chemical character of ground water and major cations and

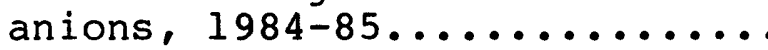

18. Graphs showing temporal variations in specific conductance, $1984-85 \ldots \ldots \ldots 63$

19. Diagram showing components of the

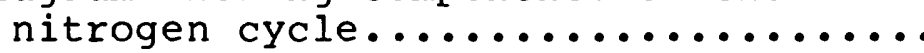

20. Map showing locations of sites sampled

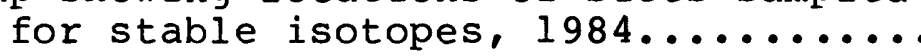

21. Diagram showing relation between delta oxygen-18 and delta deuterium analyses for whey, potato-processing wastewater, and ground-water samples,

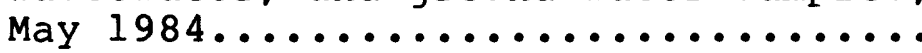

22. Map showing approximate locations of areas with ground-water contamina-

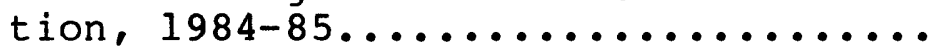

23. Graph showing total daily potatoprocessing wastewater discharge and chemical-oxygen demand, January 1984 to July 1985 . 


\section{TABLES}

Page

Table 1. Generalized physical and hydrologic charac-

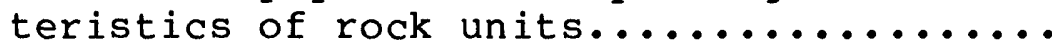

2. Characteristic contaminants associated with

selected land- and water-use practices..... 42

3. Source and significance of selected waterquality characteristics................ 44

4. Statistical summary of selected constituents,

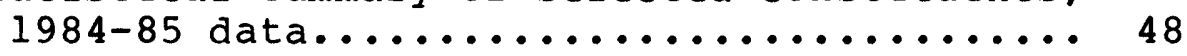

5. Summary of water analyses from wells with anomalous constituent concentrations,

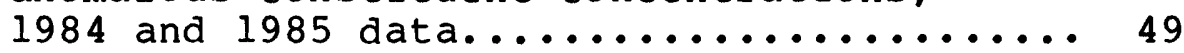

6. Selected trace element data, 1984.......... 74

7. Ground-water contaminants and probable sources, Groveland-Collins area, 1984-85

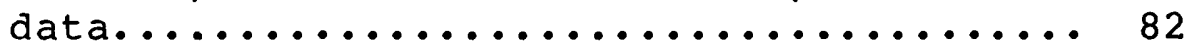

8. Pre-1984 and 1984-85 analyses of potatoprocessing wastewater and whey......... 85 


\section{CONVERSION FACTORS}

For readers who prefer to use metric (International System) units, conversion factors for inch-pound units in this report are 1 isted below. Constituent concentrations are given in $\mathrm{mg} / \mathrm{L}$ (milligrams per liter) or $\mu \mathrm{g} / \mathrm{L}$ (micrograms per liter), which are equal to parts per million or parts per billion.

Multiply inch-pound unit

By To obtain metric unit

acre

cubic foot per second $\left(f t^{3} / s\right)$

foot ( $f t$ )

gallon (gal)

inch (in.)

microsiemens per centimeter at 25 degrees

Celsius $(\mu \mathrm{S} / \mathrm{cm})$

mile (mi)

square mile $\left(\mathrm{mi}^{2}\right)$
4,047

0.02832

0.3048

0.06309

25.40

1.000

1.609

2.590

$$
\begin{aligned}
& \text { square meter } \\
& \text { cubic meter per } \\
& \text { second }
\end{aligned}
$$

meter

liter

meter

micromhos per centimeter at 25 degrees Celsius

kilometer

square kilometer

Temperature in ${ }^{\circ} \mathrm{C}$ (degrees Celsius) can be converted to ${ }^{\circ} \mathrm{F}$ (degrees Fahrenheit) as follows:

$$
{ }^{\circ} \mathrm{F}=(1.8)\left({ }^{\circ} \mathrm{C}\right)+32
$$

Sea level: In this report, "sea level" refers to the National Geodetic Vertical Datum of 1929 (NGVD of 1929)--a geodetic datum derived from a general adjustment of the first-order level nets of both the United States and Canada, formerly called "mean sea level of 1929." 


\section{HYDROGEOLOGY AND WATER QUALITY OF AREAS WITH PERSISTENT}

GROUND-WATER CONTAMINATION NEAR BLACKFOOT, BINGHAM

COUNTY, IDAHO

By

D.J. Parliman

\section{ABSTRACT}

The Groveland-Collins area near Blackfoot, Idaho, has a history of either periodic or persistent localized groundwater contamination. Water users in the area report offensive smell, metallic taste, rust deposits, and bacteria in water supplies. During 1984 and 1985, data were collected to define regional and local geologic, hydrologic, and ground-water quality conditions and to identify factors that may have affected local ground-water quality.

Wel1-construction, geologic, and water-level data were compiled for 163 wells in the Groveland-Collins and surrounding areas, and water samples from 54 sites were collected periodically and analyzed for chemical constituents.

Regional geologic features consist of basalt of the Snake River Group overlain by variably thick deposits of sediment. The ground-water system is in basalt or sedimentary interbeds, but water perched or moving through unsaturated rock adjacent to the snake River is an important component of area hydrology. Infiltration or leakage of irrigation water is the major source of ground-water recharge, and water levels may fluctuate 15 feet or more during the irrigation season. Ground-water movement is generally northwestward.

Ground water contains predominantly calcium, magnesium, and bicarbonate ions and characteristically has more than $200 \mathrm{mg} / \mathrm{L}$ (milligrams per liter) hardness. Ground water near the Groveland-Collins area may be contaminated from one or more sources, including infiltration of sewage effluent, gasoline or liquid fertilizer spillage, or land application of food-processing wastewater. 
Contamination from various sources may be sporadic or continuous and generally is limited in areal extent. Concentrations are highest immediately after ground thaw in many areas. Contamination is most frequent during spring and summer months and least frequent during winter months. Rising water levels during the irrigation season flush contaminants from previously unsaturated rock to wateryielding zones. Locally, well structure or construction may provide routes for movement of contaminants from land surface and unsaturated rock to the ground-water system. Subsurface basalt ridges impede lateral movement of water in localized areas. Ground water pools temporarily behind these ridges and anomalously high water levels result.

Maximum concentrations or values of constituents that indicate contamination were 1,450 microsiemens per centimeter specific conductance, $630 \mathrm{mg} / \mathrm{L}$ bicarbonate (as $\mathrm{HCO}_{3}$ ), $11 \mathrm{mg} / \mathrm{L}$ nitrite plus nitrate (as nitrogen), $7.3 \mathrm{mg} / \mathrm{L}$ ammonia (as nitrogen), $5.9 \mathrm{mg} / \mathrm{L}$ organic nitrogen, $4.4 \mathrm{mg} / \mathrm{L}$ dissolved organic carbon, 7,000 $\mathrm{kg} / \mathrm{L}$ (micrograms per liter) dissolved iron, 5,100 $\mathrm{gg} / \mathrm{L}$ dissolved manganese, and $320 \mu \mathrm{g} / \mathrm{L}$ dissolved zinc. Dissolved-oxygen concentrations ranged from $8.9 \mathrm{mg} / \mathrm{L}$ in uncontaminated areas to $0 \mathrm{mg} / \mathrm{L}$ in areas where food-processing wastewater is applied to the land surface.

Stable-isotope analyses may be useful in differentiating between contamination from potato-processing wastewater and whey in areas where both are applied to the land surface.

Development of a ground-water model to evaluate effects of land application of organic wastewater and organic solute loading rates on subsurface water quality is not feasible at this time.

\section{INTRODUCTION}

Ground-water contaminationl has been reported for wells within 2 to $6 \mathrm{mi}$ of Groveland, Collins, and Wadsworth Island near Blackfoot, Idaho (fig. 1; hereafter referred to as the Groveland-Collins or study area), since the 1950's

${ }^{1}$ For purposes of this report, ground water is defined as water in saturated rock (Heath, 1983, p. 4). Contaminants are defined as chemical components that are introduced into the hydrologic environment as a result of land- or water-use activities and that may limit the water's suitability for use or may result in significant degradation of water quality. 


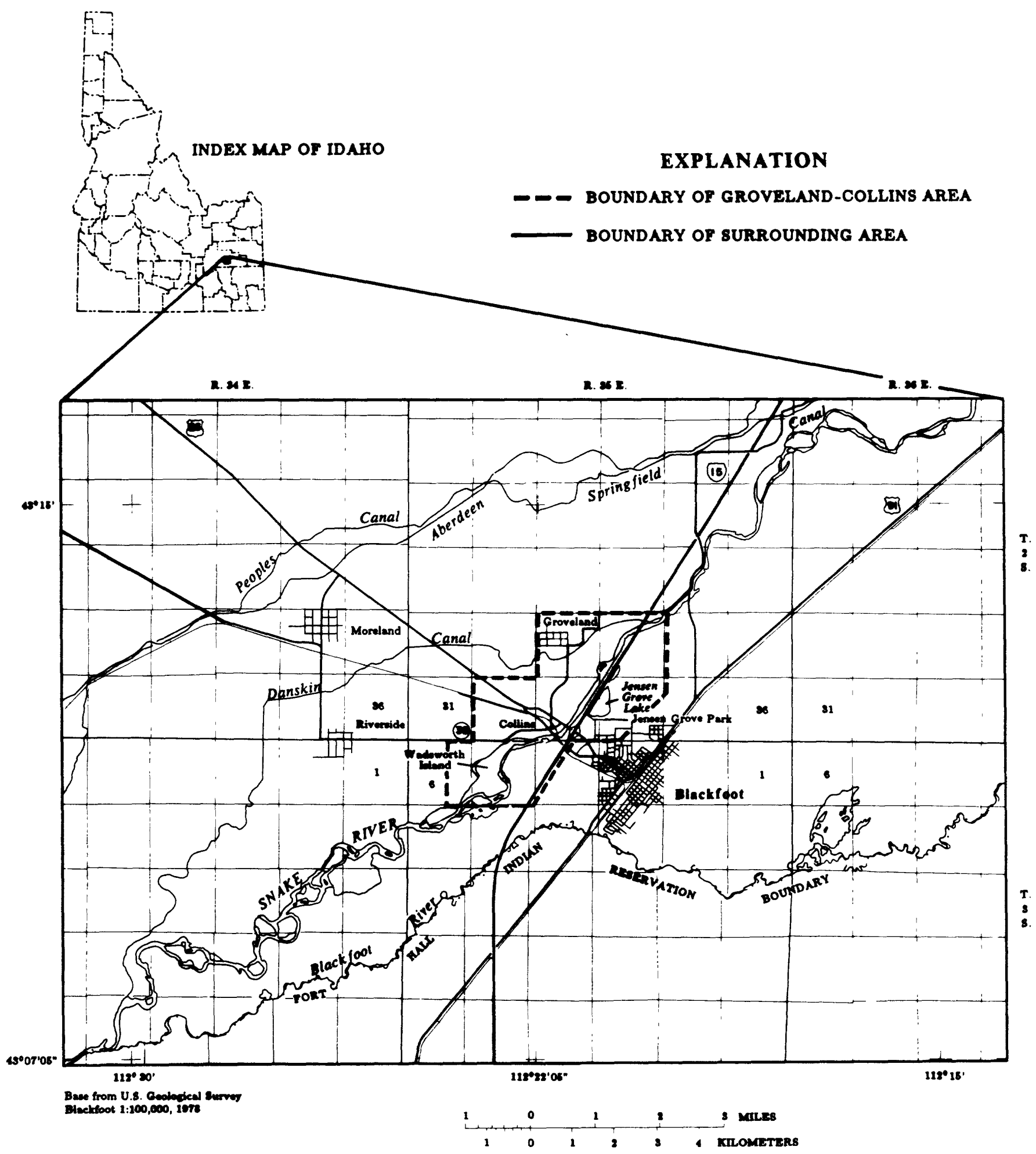

Figure 1.--Location of Groveland-Collins and surrounding areas. 
(Bingham County, 1981, p. 143). Complaints of either periodic or persistent localized ground-water contamination in these areas became noticeably more frequent in about 1974. Water users commonly reported (1) swampy or foul odor; (2) metallic taste; (3) rust clogging appliances or plumbing and staining clothes, plumbing fixtures, or building exteriors; (4) a black, stringy, algae-like growth in plumbing fixtures; and (5) health problems, particularly those affecting the digestive tract. Reported contamination problems were most noticeable in early spring, particularly after ground thaw, and in late summer.

Between 1974 and 1983, parts of areas near Groveland and Collins were included in at least six ground-water studies by county, state, or private agencies. Analyses of ground-water samples collected for these studies defined a few of the contaminants, including total coliform bacteria, dissolved iron or dissolved manganese, and a few anomalous concentrations of dissolved $z$ inc or nutrients (nitrogen and phosphorus compounds). Although some contaminants were generally described in these studies, specific sources of contamination were not identified. Contamination sources suggested by the studies included: (1) Inadequate well construction; (2) improper or inadequate construction of subsurface sewage-disposal systems; (3) increased density of subsurface sewage-disposal systems; (4) inadequate filtering capacities of soils; (5) leakage from manufacturing or sewage wastewater lagoons; (6) leachates from historical landfill sites; (7) leachates from historical disposal of solid organic wastes in trenches, gravel pits, and dry river channels; or (8) infiltration of relatively large volumes of food-processing wastewater used for irrigation (Bingham County, 1981; Forsgren-Perkins Engineering, 1982; Stewart, $1983)$.

In 1983, the U.S. Geological Survey, in cooperation with the Idaho Department of Health and Welfare, Division of Environment, began a 2-year study to determine the causes of ground-water contamination in the Groveland-Collins area. Results of the study are described in this report. Data collected in support of the hydrologic and water-quality components of this study were compiled and presented in a separate report (Parliman, 1986).

\section{Purpose and Scope}

The primary purposes of this 2-year study were to describe (1) hydrogeology and water quality in the area near Groveland and Collins; (2) extent and degree of areal and vertical ground-water contamination and seasonal changes in 
concentrations of selected chemical constituents; and (3) most probable sources and causes of the contamination, with consideration for the mechanisms of reaction between soil or rock and manufacturing effluent or other percolates. A secondary purpose of this study was to determine the feasibility of constructing a solute-transport model for use by the Idaho Department of Health and Welfare to evaluate effects of land application of organic wastewater and solute-loading rates on the quality of water in both the saturated and unsaturated rocks.

The scope of the first year of study included (1) compiling existing geologic, hydrologic, and water-quality data; (2) inventorying wells; (3) obtaining periodic onsite measurements of depth to water, $\mathrm{pH}$, specific conductance, dissolved oxygen, alkalinity, and water temperature from selected wells; (4) constructing water-level contour maps and hydrogeologic cross sections to define areal hydrology; (5) obtaining water samples from selected wells at determined intervals and analyzing the samples for selected cations, anions, nutrients, organic constituents, and trace elements; (6) defining areal extent and degree of ground-water contamination and seasonal changes in concentrations of selected constituents; (7) determining the most probable sources and causes for localized ground-water contamination; and (8) determining chemical mechanisms involved in release and transport of contaminants in the ground water.

The scope of the second year of study included (1) defining hydrology near Jensen Grove Lake (fig. 1), with emphasis on the general direction of ground-water movement and seasonal water-quality trends; (2) defining surface- and ground-water relations in an area used for perennial disposal of potato-processing wastewater (hereafter referred to as the potato wastewater field); (3) installing several monitoring wells near Jensen Grove Lake and the potato wastewater field; (4) estimating hydraulic properties of unsaturated rock and defining water quality in the potato wastewater field; and (5) evaluating the feasibility of constructing a solute-transport model for use by the Idaho Department of Health and Welfare.

\section{Methods}

Well-construction, geologic, water-level, and waterchemistry data were compiled for 70 wells in the GrovelandCollins area. Comparable data were collected for an additional 81 wells in the surrounding area to provide background data. Twelve monitoring wells were installed in 1985, and locations of all 163 wells are shown in figure 2 (back of report). 
Selection of wells was based on the following considerations: (1) Availability of well-construction and lithologic log information, (2) availability of pre-1984 waterlevel or water-quality data, (3) proximity of a well to areas with reported water-quality problems, (4) accessibility of well for water-level measurements, (5) distance from the well to water-sampling point, (6) visible condition of the well casing, and (7) well-owner permission for long-term monitoring. Well-inventory data (onsite and drillers' log information about well location, construction, lithology, use, and water-yielding zones) for these wells were compiled in a separate report (Parliman, 1986).

From January to November 1984, water-level measurements were made about bimonthly in 58 wells in the GrovelandCollins area and 81 wells in the surrounding area. In 1985, water-level measurements were made periodically in 50 wells in the Groveland-Collins area and 3 wells in the surrounding area. Because topographic maps have not been revised since 1971, all wells used for water-level monitoring near Groveland, Collins, and Jensen Grove Lake were surveyed with level lines to provide a comparative land-surface altitude base. Land-surface altitudes for wells in the surrounding area were interpolated from available U.S. Geological Survey topographic maps.

Pre-1984 water-quality data were compiled for 51 wells in the Groveland-Collins area. During 1984 and 1985, water-quality data consisting of onsite and laboratory analyses were collected from 54 inventoried sites. Methods used for sample collection, preservation, and analysis were described in a separate report (Parliman, 1986, p. 5). Onsite analyses included specific conductance, water temperature, $\mathrm{pH}$, dissolved oxygen, and carbonate-bicarbonate determinations. Laboratory analyses included specific major cations, major anions, nutrients, trace elements, and dissolved organic carbon. A few samples were analyzed for methylene blue active substance, carbamate insecticides (specifically aldicarb compounds), and selected stable isotopes. Locations of wells for which water-quality data are available are shown in figure 3. Selected 1984-85 data are summarized and discussed in this report. Pre-1984 and 1984-85 water-level and water-quality data were compiled in a separate report (Parliman, 1986).

Reliability of available data is an important consideration when comparing analyses. Some apparent variation in water-quality characteristics may be based on inaccuracies in data, the result of changes in sample collection techniques or onsite and laboratory analytical methods, or perhaps errors in data transcription or recording. Accuracy of data used in this report was checked by several quality 


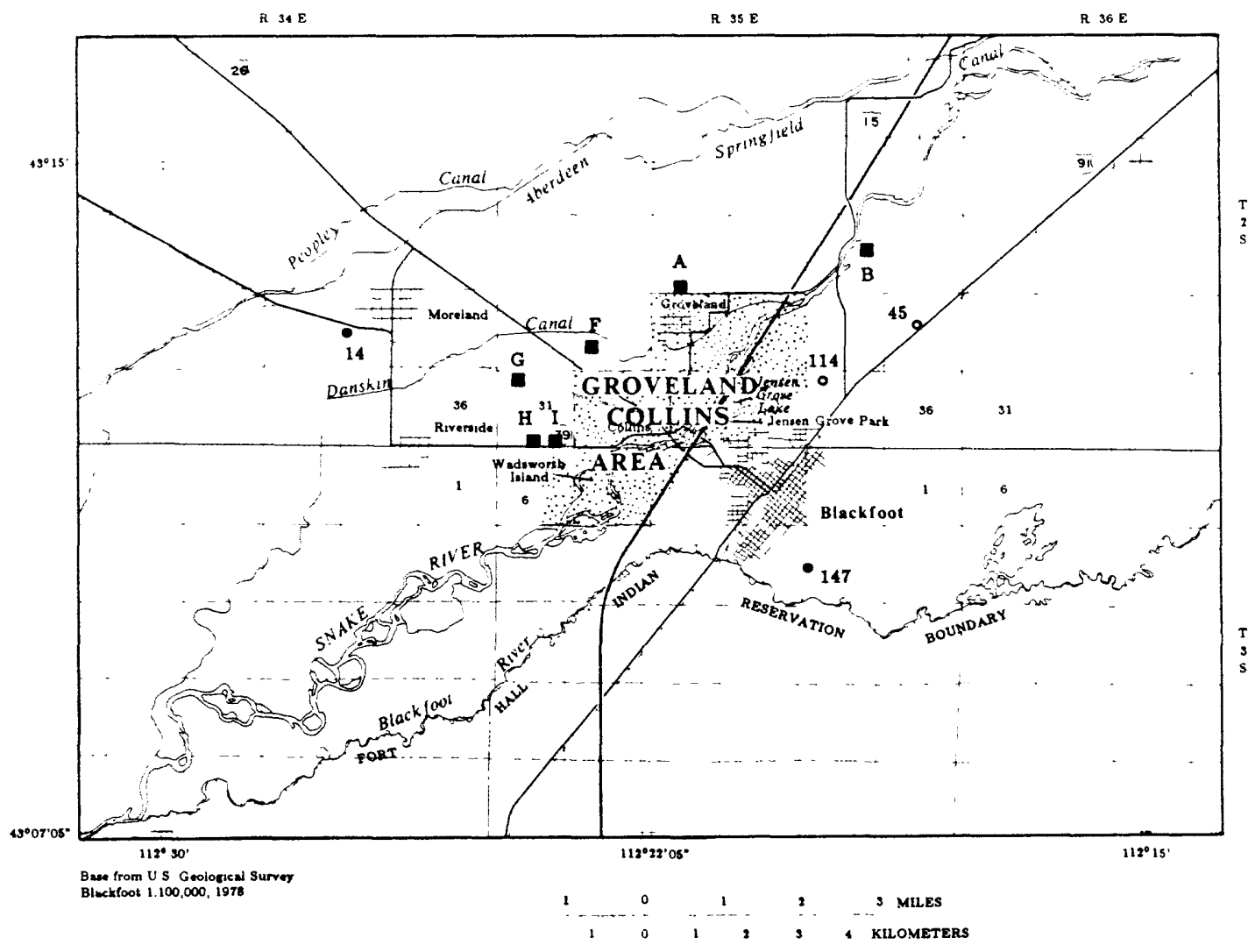

DETAIL OF

GROVELAND-

COLLINS AREA

(shaded area above)

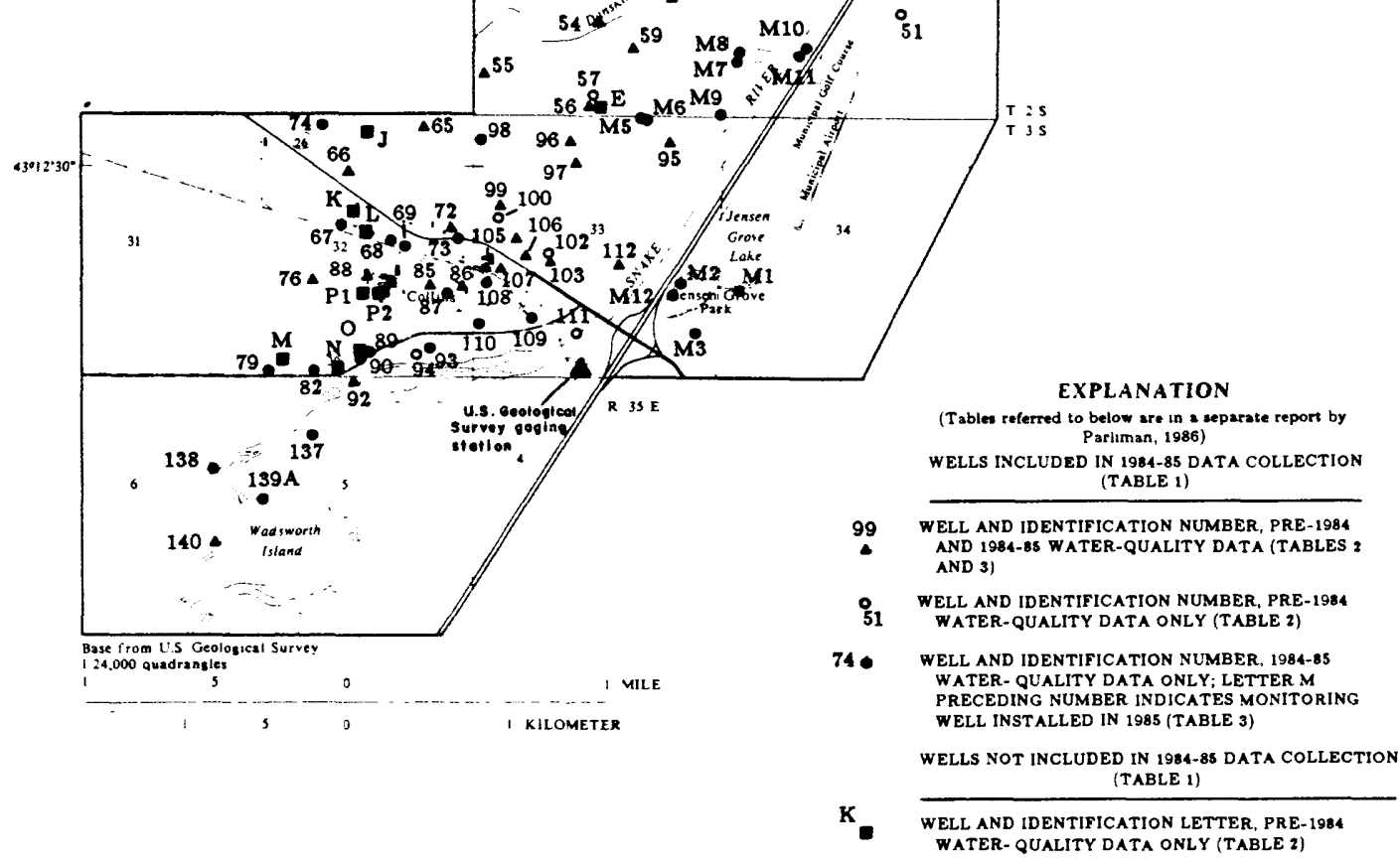

Figure 3.--Location and identification of wells with water-quality data, Groveland-Collins and surrounding areas, pre-1984 and 1984-85. 
assurance techniques, including cation-anion balance, specific conductance to dissolved-solids ratio, and comparison of characteristic concentrations (to detect possible gross reporting errors). Cation-anion balance and values of conductance-solids ratios for 1984-85 data are listed in a separate report. Most pre-1984 analyses, however, lacked one or more components necessary to perform these quality assurance techniques.

Data for estimating surface- and subsurface-water relations were compiled from (1) low-flow discharge measurements made at three locations on the Snake River adjacent to the potato wastewater field, (2) mean daily water-surface altitudes recorded at the U.S. Geological Survey gage on the Snake River at Blackfoot (fig. 3), (3) daily discharge records for irrigation canals in the Blackfoot area, and (4) periodic water-level measurements in Jensen Grove Lake (fig. $3)$ and selected canals. Water-surface altitude of Jensen Grove Lake at the outlet gate was established by level-1ine survey.

Information on historical land use, river channel alterations, and areas of possible ground-water contamination was provided by residents, aerial photographs, and local, county, or state agency personnel. Some additional historical information was obtained from unpublished records.

\section{Acknowledgments}

Information necessary for completion of this project was furnished by private landowners; public and private business personnel; food-processing personnel; city, county, State, and Federal agency personnel in Idaho; and Federal research personnel nationwide. Management personnel with NonPareil Processing Corporation provided information about company operations and allowed access to company property for data collection. Personnel with Kraft, Inc.; Blackfoot Parks Department; Bingham County; Idaho Department of Health and Welfare, Southeastern District Health Department and Division of Environment (Pocatello and Boise); Idaho Department of Transportation (Pocatello); and Idaho Department of Water Resources (Boise and Idaho Falls) provided valuable information on historical land and water uses and allowed access to private or municipal properties for data collection. Equipment and expertise from U.S. Soil Conservation Service and U.S. Forest Service personnel were provided for soil-sampling parts of this project. U.S. Geological Survey research personnel in Reston, Va., Denver, Colo., and Menlo Park, Calif., provided expertise and advice on biochemical, geochemical, and stable-isotope aspects 
throughout the project. Interest and project support by Idaho Association of Commerce and Industry, Potato Committee members, also were appreciated.

\section{DESCRIPTION OF THE STUDY AREA}

The Groveland-Collins area in Bingham County comprises about $7 \mathrm{mi}^{2}$ adjacent to the Snake River near Blackfoot (fig. 1), and includes lands near the towns of Groveland and Collins, Wadsworth Island, and the Blackfoot municipal recreation park (Jensen Grove Lake, Jensen Grove Park, and Blackfoot airport and golf course). Landsurface altitudes in the study area range from 4,500 ft above sea level near Groveland to 4,460 ft near Wadsworth Island. The land slopes generally southwestward and is nearly level in many places but, in some parts of the area, extensive changes were made to the land surface during the $1960^{\prime} \mathrm{s}$ and $1970^{\prime} \mathrm{s}$, particularly during construction of Interstate Highway 15.

Climate is semiarid, characterized by cold, wet winters and hot, dry summers. Mean annual precipitation between 1970 and 1984 was about 10 in.; precipitation is greatest during winter and spring and least during summer, particularly July and August. The mean annual air temperature is about $47^{\circ} \mathrm{F}\left(8.5^{\circ} \mathrm{C}\right)$. Highest mean temperatures are recorded most often in July, and lowest, most often in January (National Oceanic and Atmospheric Administration, 1970-84). Large daily ranges in air temperature are common and, during winter months, extended periods of extreme cold occasionally cause ice dams to form, which may result in localized flooding along the Snake River.

Soils in Bingham County are varied and complex. Salzmann and Harwood (1973) provided a detailed description of regional soils and soil properties, and generalized information is available in reports by Bingham County (1981) and Forsgren-Perkins Engineering (1982). Soil frost information is particularly important to the discussion of ground-water contamination problems. The following description of soil frost conditions was provided by Chad McGrath (U.S. Soil Conservation Service, Pocatello, written commun., 1985): (1) The soil surface begins to freeze and thaw daily in late October, (2) soil frost reaches its maximum depth in late January, (3) daily freeze-thaw cycles in the spring begin about mid-March, and (4) soil frost usually is gone by mid-April.

About 32 percent of Bingham County's population growth from 1970 to 1980 was in the Groveland-Collins and surrounding areas. Census population figures are not tabulated for the small communities in these areas, but estimates of 1980 
population are 600 in Groveland, 800 in Collins, 1,400 in Moreland, 900 in Riverside, and 1,700 in rural areas (Forsgren-Perkins Engineering, 1982, p. 24-25). The 1980 census for Blackfoot showed a population of 10,065 (Allan Porter, Idaho Department of Commerce, oral commun., $1985)$.

The economy of Bingham County is based on agricultural production and food processing, energy research, wholesale and retail trade, recreation, and tourism. About 900 people are employed at potato-processing companies in Collins, but most jobs are in Blackfoot, at the Idaho National Engineering Laboratory ( $50 \mathrm{mi}$ northwest of Blackfoot), or are related to agriculture.

Four major types of land use are single-family residences, commercial and manufacturing development, irrigated agriculture, and municipal recreation or services. Singlefamily residences are in and near small communities or along county roads. Most rural residences are on small acreages, but community, subdivision, and mobile home parks may be clustered; some locations may support 20 to 30 houses or mobile homes per 40 acres. Most residences have individual wells for water supply and a septic-tank soil-percolation (drain field or seepage pit) system for sewage and wastewater disposal. Mobile home parks generally have a community well and a wastewater lagoon.

Land in and near Collins is used primarily for food processing, manufacturing, and commercial development. Most businesses are associated with agricultural equipment and supply, including bulk liquid fertilizer and dry chemical storage. Both solid and liquid wastes from potato- and cheese-processing businesses are used locally for animal feed supplements or are applied to land, principally through flood or sprinkler irrigation. Large volumes of potatoprocessing wastewater initially are screened to reduce organic solids, then piped to company-owned spray fields to irrigate pasture and forage crops. Whey (cheese-processing wastewater) is most commonly applied to pasture for fertilizer.

Relatively small acreages in the Groveland-Collins area and most land in the surrounding areas support irrigated agriculture and animal production. A complex system of canals and ditches provides water from the Snake River for crop and pasture irrigation. Domestic water supplies and some stock or irrigation water supplies are from individual wells. Individual businesses have wells for water supply and septic-tank soil-percolation systems or lagoons for sewage and wastewater disposal. Some seepage pits are used to dispose of runoff from parking lots and business yards. 
Selected land-use features are shown in figure 4. More detailed information about housing densities and sewage and wastewater disposal is given in reports by Bingham County (1981) and Forsgren-Perkins Engineering (1982).

\section{GEOLOGIC AND HYDROLOGIC FRAMEWORK}

Below land surface, water moves through soil and rock. Soil is the layer of material that supports plant growth, and rock is the naturally formed consolidated or unconsolidated material that generally underlies soil. Direction of water movement through soil and rock is defined by physical forces such as gravity or atmospheric and hydraulic pressure. Paths and rates of movement, volumes of water, and most water-quality characteristics are strongly influenced by spatial distribution, physical and hydrologic characteristics, and mineral composition of the rocks through which water moves. A study of subsurface water, particularly water quality, requires an understanding of rock distribution and characteristics.

\section{Geology}

Description of the geologic framework of the Grovelandcollins and surrounding areas in this report will be brief. Detailed discussions of area geology and geologic history are included in reports by Robinette and Matzner (1980), Bingham County (1981, p. 5-13), Scott (1981), and Greeley (1982).

Principal rock units include modern snake River flood-plain deposits, older Snake River terrace deposits and glacial fill, windblown sand and loess deposits, lake and playa deposits, and basalt of the Quaternary snake River Group. Surface distribution of these rock units is shown in figure 5, and their generalized physical and hydrologic characteristics are summarized in table 1 .

Unconsolidated sand, gravel, and silt or clay are the predominant sediments. Silt or clay $0.5 \mathrm{ft}$ or more thick overlies basalt in each monitoring well completed in basalt, but reports of fine-grained sediment beds or lenses overlying basalt are sporadic in most other areas. The intermittence of drillers' log reports of clay and silt may indicate that fine-grained sediments were deposited in local depressions on the basalt surface or are areally widespread but are thin units (Iess than I ft thick) that are not easily detected. These fine-grained sediments are particularly important to the movement of subsurface water. 
R. $35 \mathrm{E}$.

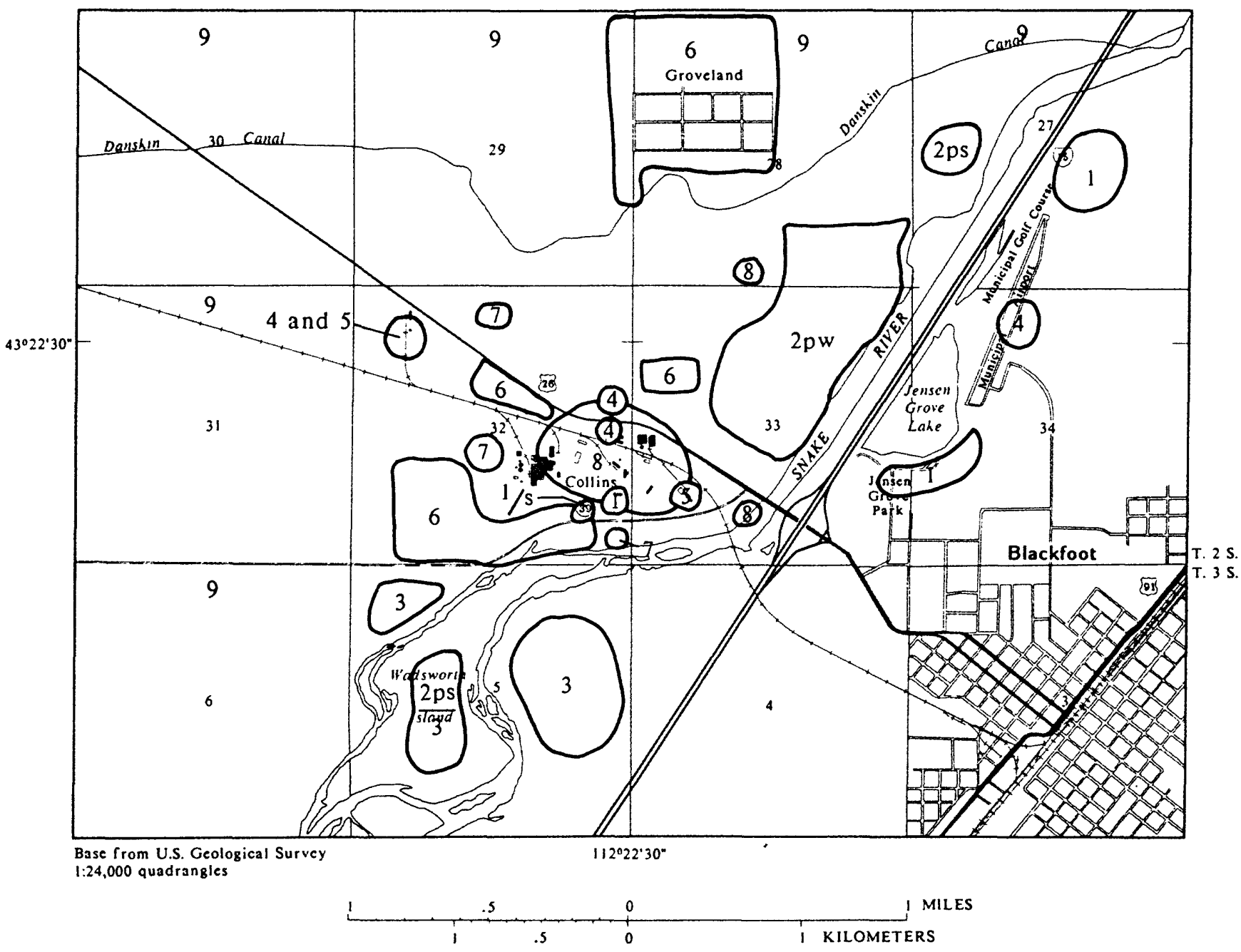

EXPLANATION

1 Pre-1980 landfill; landsurface dumping of solid wastes or trenched organic wastes reported

2 Pre-1984 and 1984-85 land application of potatoprocessing wastewater ( $p w$ ) or solids (ps)

3 Pre-1984 land application of whey reported

4 Bulk underground gasoline storage or historical gasoline spill (s)
5 Bulk fertilizer or pesticide storage or distribution

6 High density of individual septic-tank systems

7 Sewage-wastewater lagoon

8 Large-capacity subsurface sewage-wastewater systems; land-surface seepage pits.

9 Primarily irrigated pasture or cropland; single-family homes along highways; sparse commercial development

Figure 4.--Selected land-use features. 


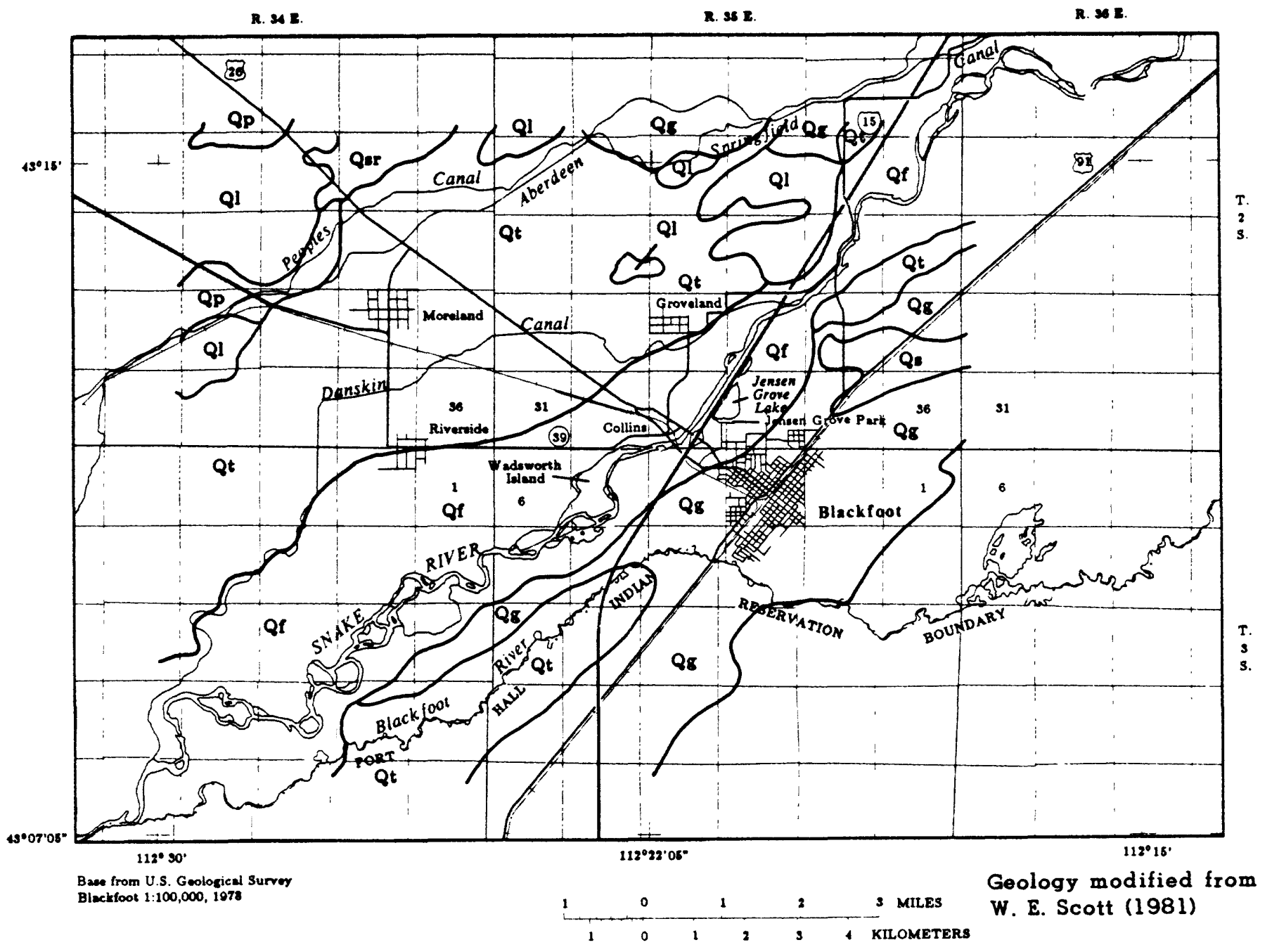

\section{EXPLANATION}

CORRELATION OF ROCK UNITS

\section{LIST OF ROCK UNITS}

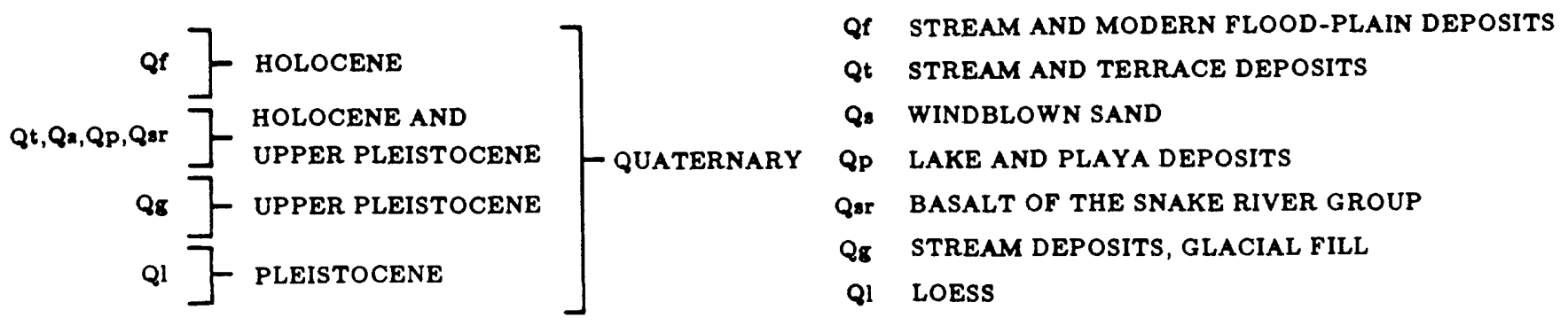

Figure 5.--Generalized surficial geology. 


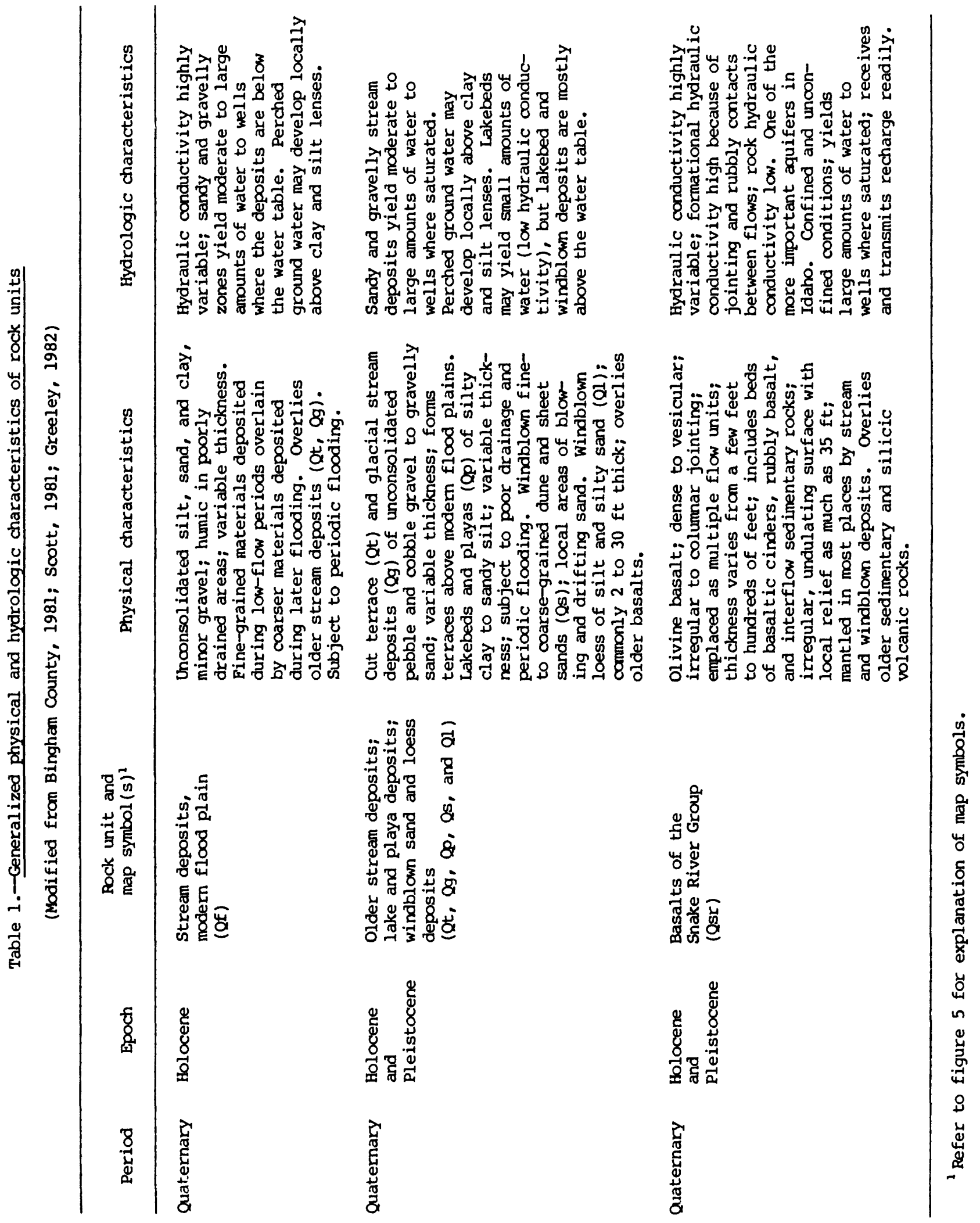


Basalt and associated interbeds underlie the entire area. Spatial, physical, and hydrologic characteristics of basalt of the snake River Group are extremely diverse. Basalt surfaces, exposed north and west of the area, are described as "hummocky," with as much as $35 \mathrm{ft}$ of local relief, and are characterized as having collapse depressions, pressure ridges, pressure plateaus, flow ridges, and lava toes (Greeley, 1982, p. 2705). Structural contours of the basalt surface shown in figure 6 illustrate the irregular, hummocky character of the basalt.

Individual basalt flows or basalt flow units may be highly fractured and jointed or massive (unfractured, unjointed). Interbeds vary areally and with depth but may include volcanic cinders, rubbly basalt, or sedimentary materials.

Electrical resistivity studies by Robinette and Matzner (1980, p. 20-23) provide geologic information to depths of about $1,500 \mathrm{ft}$ below land surface near Blackfoot. Data from an east-west resistivity profile about $1 \mathrm{mi}$ north of Riverside show multiple basalt flows extending from near land surface to the bottom of the geoelectrical model.

Data from a resistivity profile extending southeastward through Collins to Blackfoot indicate that, northwest of Collins, basalt of the Snake River Group is about 1,300 ft thick and, beneath Blackfoot, is $630 \mathrm{ft}$ thick and overlies a layer of saturated sand and gravel. Wells about 400 ft deep in the Groveland-Collins area do not extend through the full thickness of the basalt. Southeast of Blackfoot, an 868-ft well (section 2, township 3 south, range 35 east) penetrates about $230 \mathrm{ft}$ of unconsolidated sediment, $312 \mathrm{ft}$ of clayey basalt (Snake River Group), $185 \mathrm{ft}$ of consolidated sediment, and 141 ft of saturated silicic volcanic rocks (older than basalt of the Snake River Group). This information indicates a rapid thinning or pinching out of basalt beneath the Blackfoot area.

Data from a north-south resistivity profile beginning east of the Blackfoot golf course indicate about $600 \mathrm{ft}$ of basalt underlain by a thick sequence of clay, then by saturated sand and gravel. The basalt thins and the clay thickens toward the northeast.

Many of the subsurface lithologic features of the Groveland-Collins area are described in figures 7B-7F. Lines of sections are shown in figure 7A. Sections presented in these figures (particularly figs. 7D, 7E, and 7F) were chosen to define geologic and hydrologic conditions in section 33, township 2 south, range 35 east; specifically, the configuration of the basalt surface (fig. 


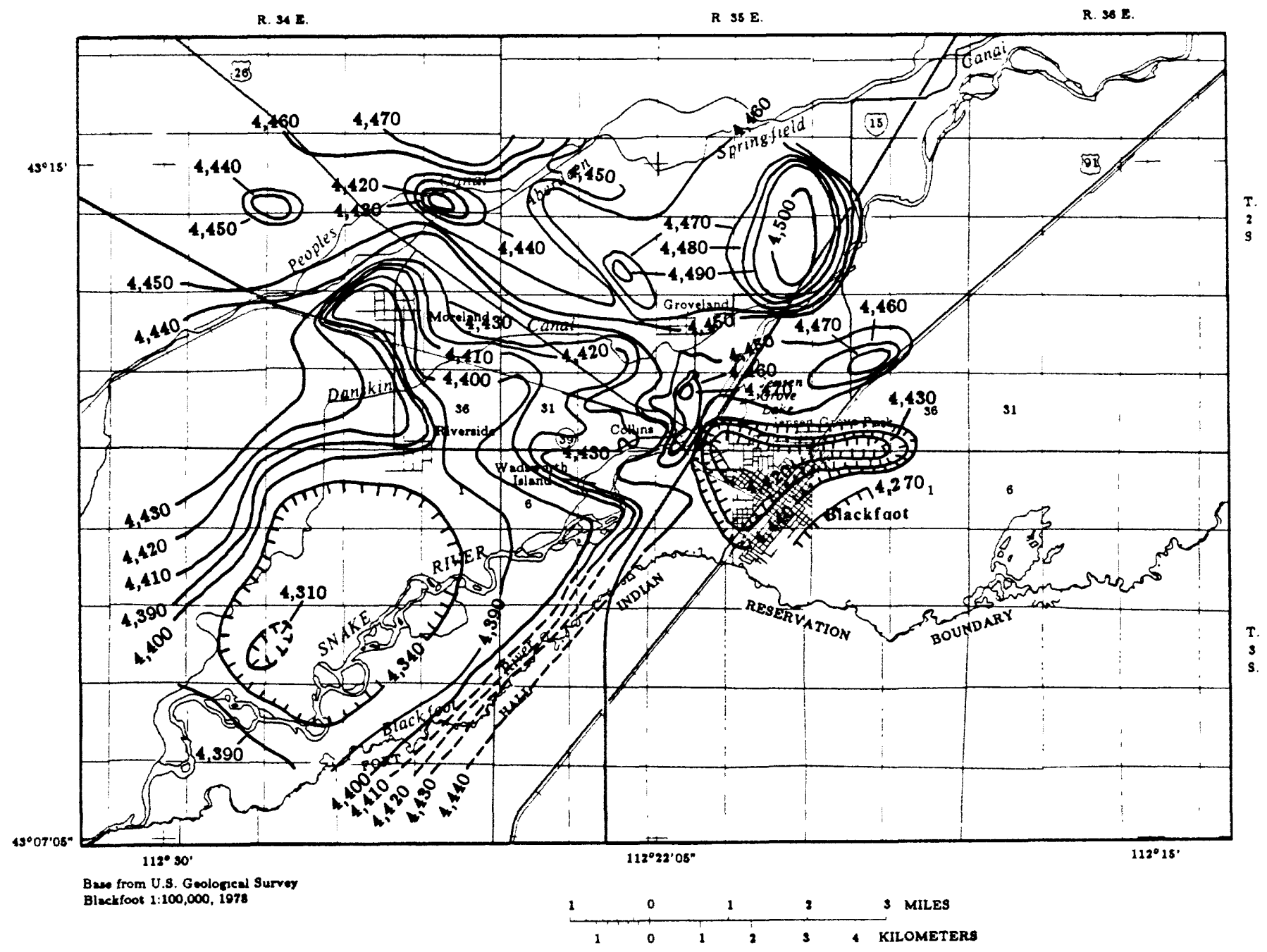

EXPLANATION

- 4,450- STRUCTURE CONTOUR--Showe altitude

of top of basalt, in feet above

sea level. Dashed where approx-

imately located. Contour inter-

vals variable

TTTTT STRUCTURAL DEPRESSION

Figure 6.--Structural contours of the basalt surface. 


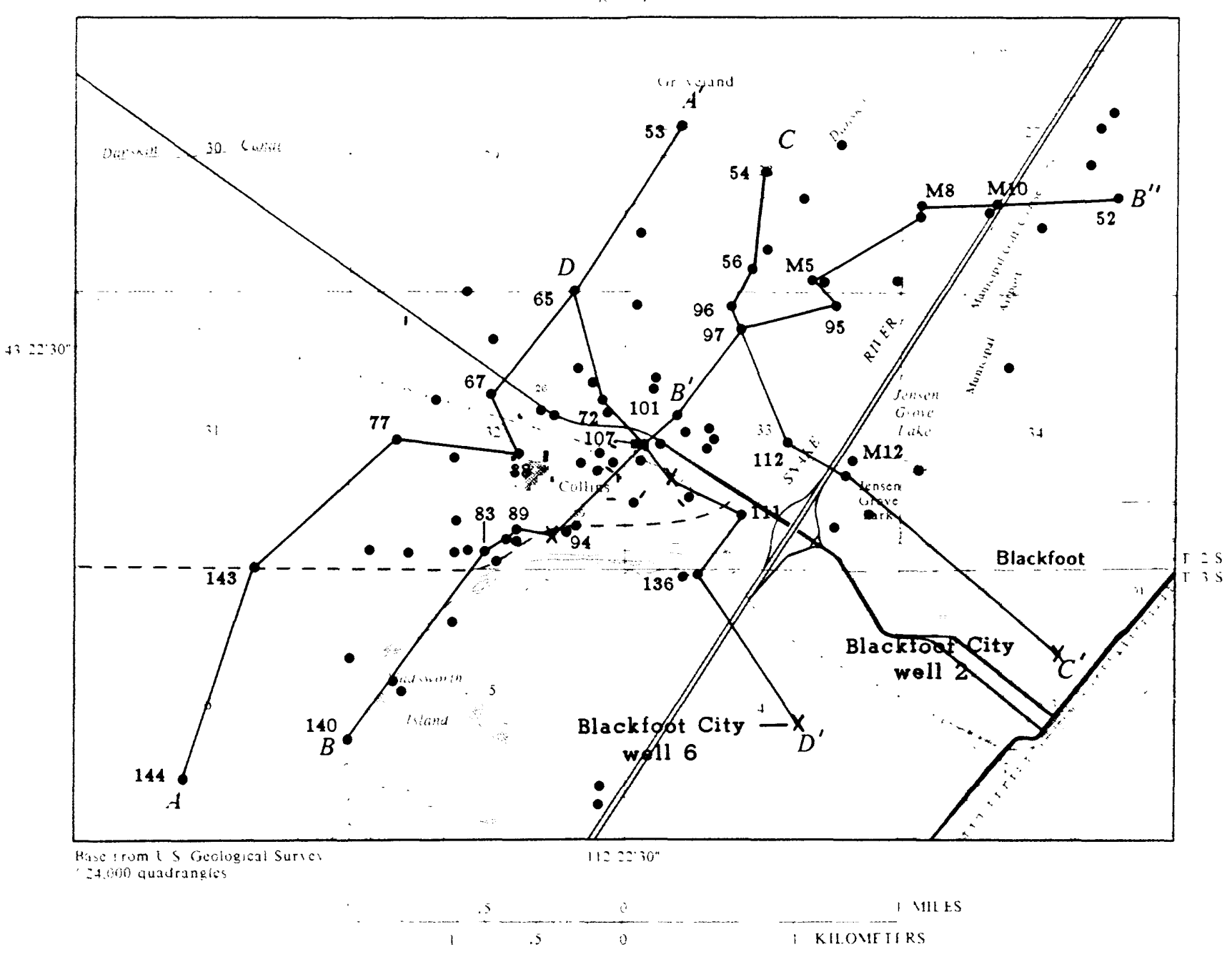

FIGURE 7A

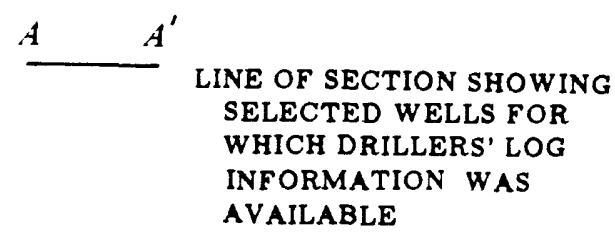

56 WELL LOCATION AND NUMBER (PARLIMAN, 1986)

- WELL, 1984 AND 1985 INVENTORY

$X$ WELL LOCATION; WELL NOT INCLUDED IN REPORT BY PARLIMAN (1986), BUT DRILLERS' LOG LITHOLOGIC INFORMATION AVAILABLE

\section{EXPLANATION}

FIGURES 7B-7F

(HORIZONTAL DISTANCE NOT TO SCALE)

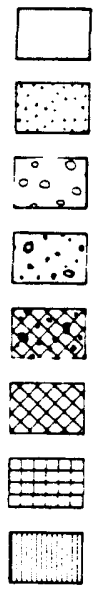

WELL CASING, TOP OF CASING SHOWN IS LAND SURFACE

WELL CASING, PERFORATED

BASALT SURFACE, APPROXIMATE

$\nabla \quad$ ALTITUDE OF HIGHEST AND LOWEST WATER LEVELS DURING 1984 AND 1985 (PARLIMAN, 1986)

CINDERS OR CINDERS ? INFORMATION NOT AND BASALT RUBBLE SPECIFIC OR NOT AVAILABLE

Figure 7A.--Locations of selected wells and comparison of well data. 


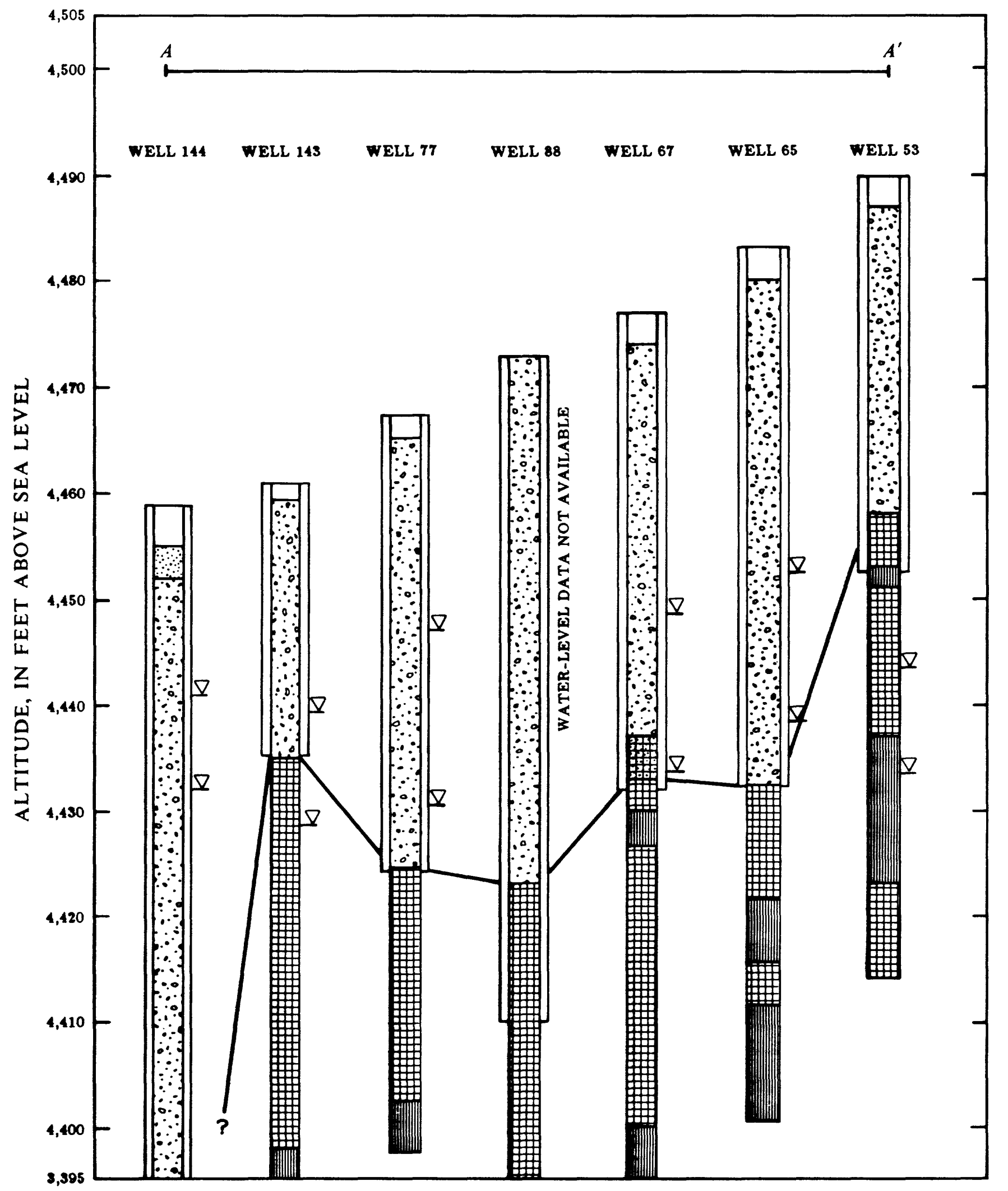

Figurc 7B.--Lithology, well construction, and range of water levels, section A-A'. 


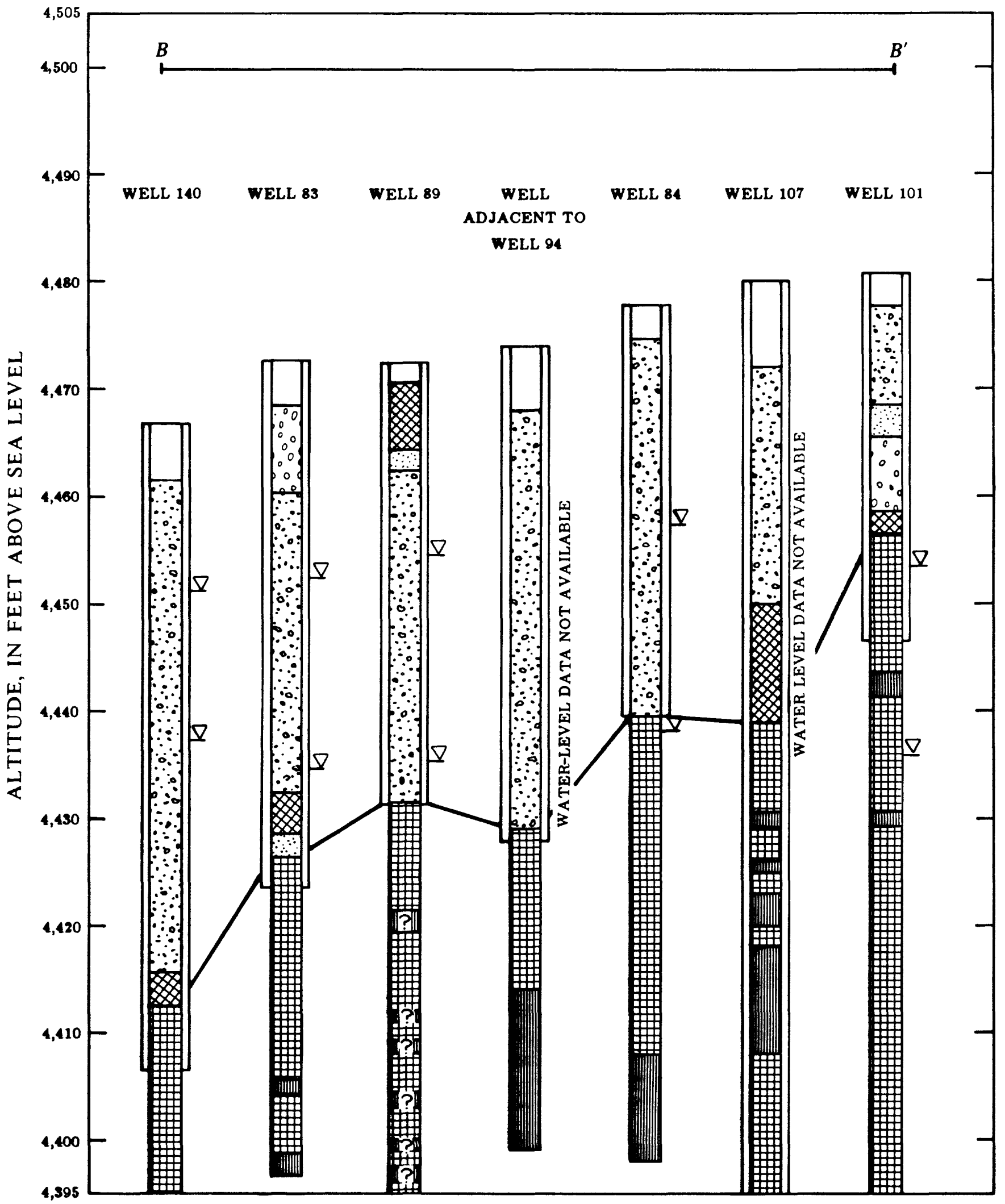

Figure 7C.--Lithology, well construction, and range of water levels, section B-B'. 


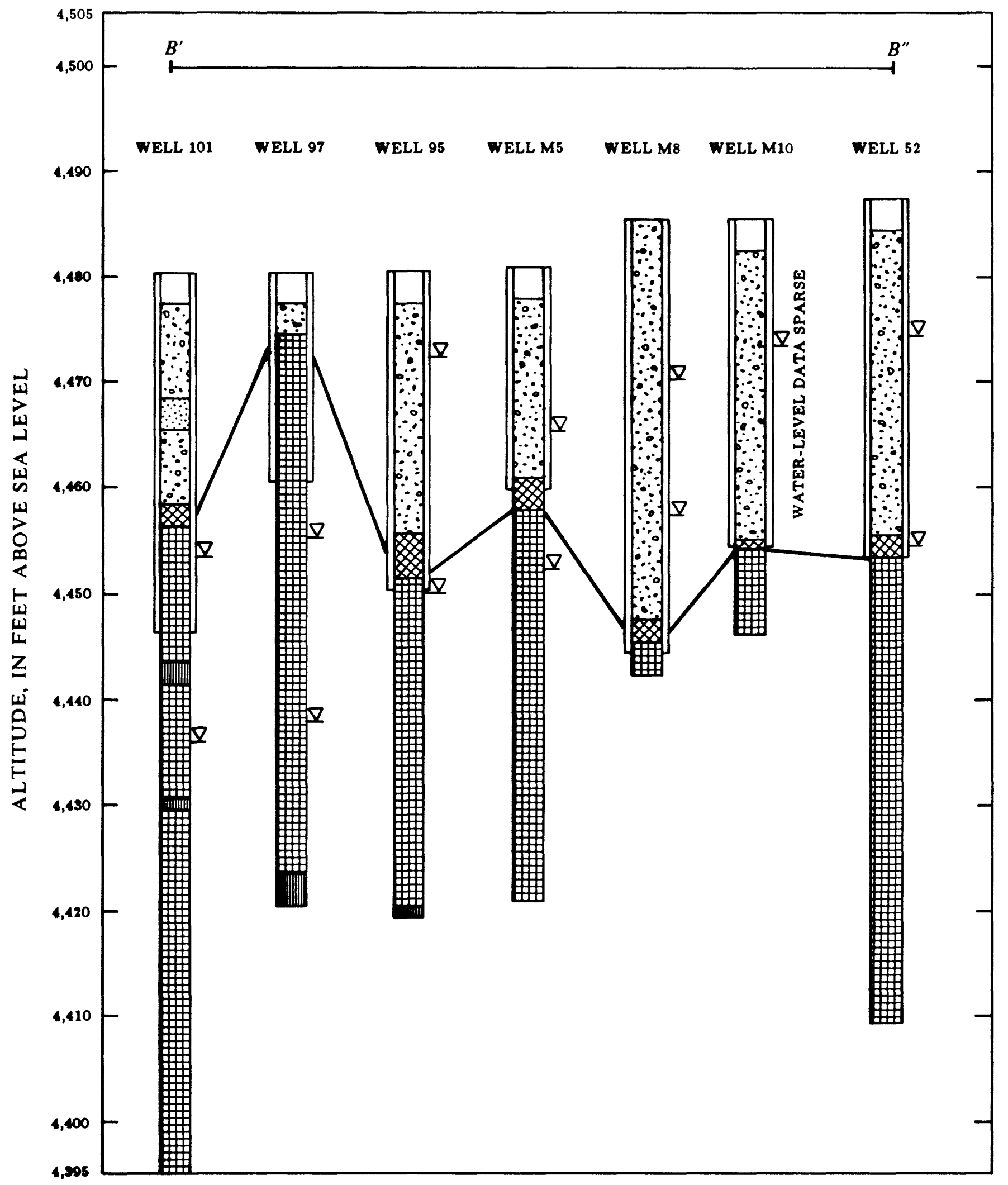

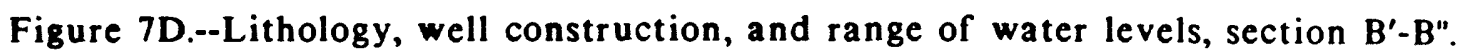




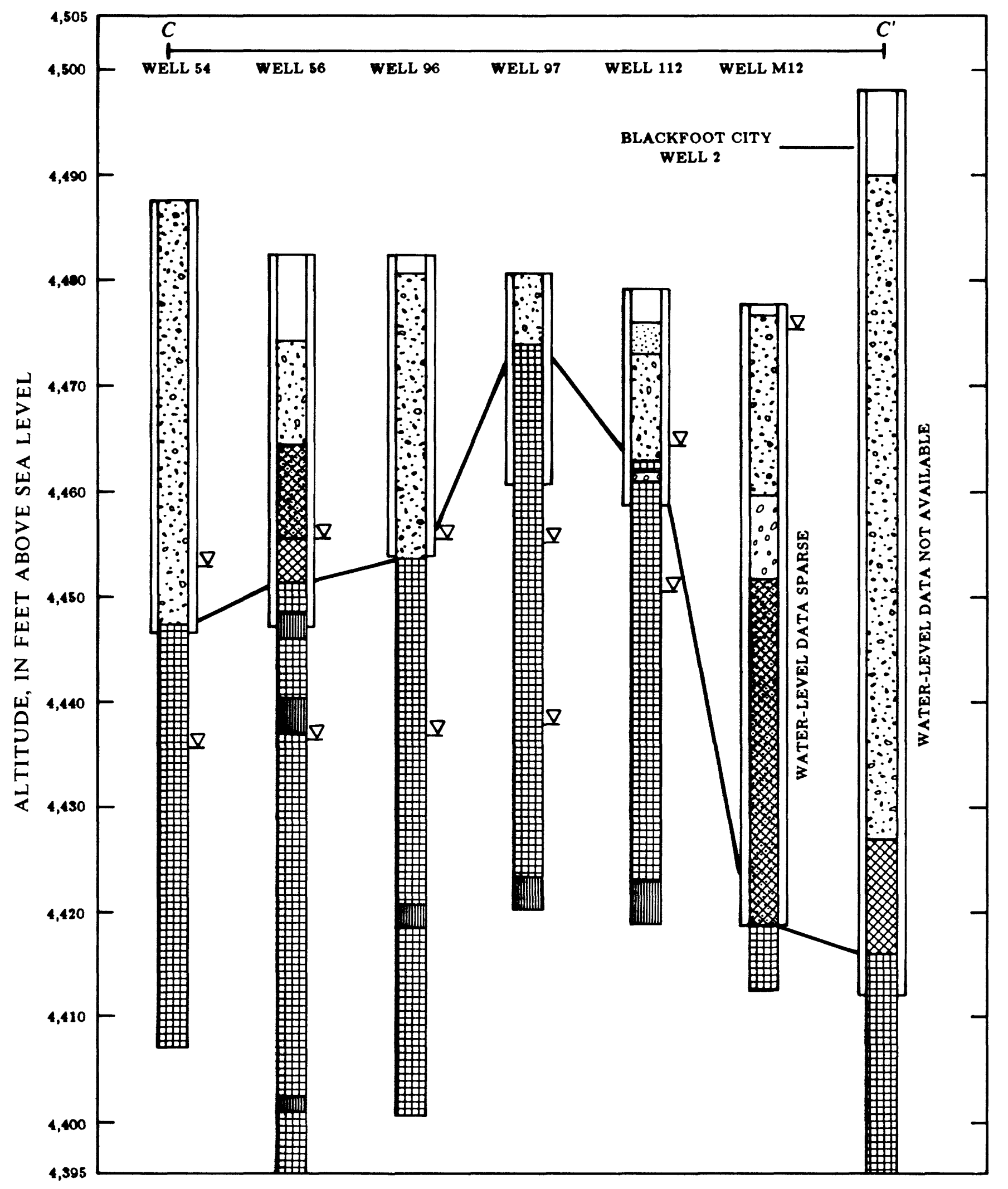

Figure 7E.--Lithology, well construction, and range of water levels, section C-C'. 


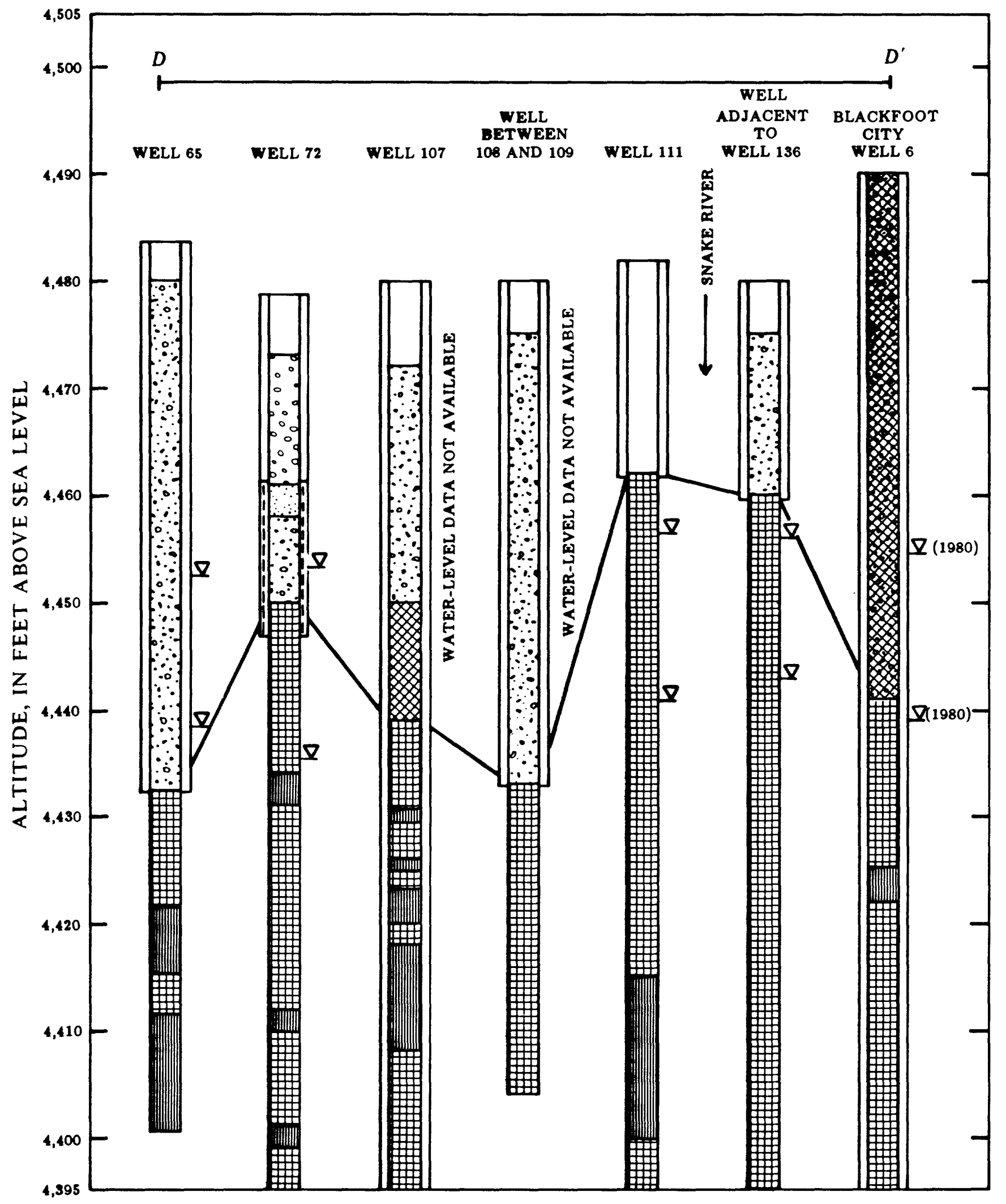

Figure 7F.--Lithology, well construction, and range of water levels, section D-D'. 
6), character and relation of sediment overlying the basalt, relation of changing water levels to rock type, and relation of well construction to geology and water levels. Figures 7B-7D represent the lithology underlying nearly every type of land use in the Groveland-Collins area except solid-waste landfill operations (fig. 4).

Figure $7 B$ (section $A-A^{\prime}$ ) shows the lithology of selected wells that are in a line nearly parallel to the Snake River but that are neither adjacent to the river nor within the historical flood channel. Land surface and the top of the basalt slope southwestward. No clay beds overlie the basalt.

Reported lithology of selected wells adjacent to the Snake River within the historical flood channel is presented in figures 7C-7D (sections $B-B^{\prime}$ and $B^{\prime}-B^{\prime} '$ '). These sections show a level or southwestward-sloping land surface underlain by varying thicknesses of sediment, a southwestward-sloping basalt surface in B-B', and an undulating basalt surface in $B^{\prime}-B^{\prime} '$. Beds of clay or silt 1 to 4 ft thick immediately overlie basalt at all sites except well 97 in section $B-B^{\prime}$ but are less common and at erratic intervals in places along section $B^{\prime}-B^{\prime} '$.

Sections $C-C^{\prime}$ and $D-D^{\prime}$ in figures $7 \mathrm{E}-7 \mathrm{~F}$ represent lithology under and on both sides of the Snake River in the Groveland-Collins area. In section C-C', land-surface altitudes decrease toward the Snake River, clay beds overlie basalt at Blackfoot city well 2 and well 56, and a prominent ridge of basalt peaks at well 97 and declines steeply toward Blackfoot. In section D-D', land-surface altitudes decrease toward the Snake River, clay overlies basalt at well 107 , and the undulating basalt surface is highest beneath the Snake River (well 1ll) and lowest beneath Collins (between wells 108 and 109 ).

\section{Surface Water}

Major surface-water features in the Groveland-Collins and surrounding areas are the Snake River, Jensen Grove Lake, and an extensive network of irrigation canals. Leakage and infiltration of water from these sources, applied irrigation water, and precipitation contribute significant amounts of recharge to the ground-water system.

The Snake River flows generally southwestward at a gradient of about $13 \mathrm{ft} / \mathrm{mi}$. Its channel is wide, is relatively shallow, and braids around many small islands. During construction of Interstate Highway 15 in the early $1960^{\prime} \mathrm{s}$, about $2 \mathrm{mi}$ of channel upstream from the U.S. Highway 
26 bridge at Collins was straightened and the banks were diked to accommodate a 500-year flood (U.S. Department of Housing and Urban Development, 1979, p. 7-9).

Former flood plains and river channels northwest of the straightened channel were filled and leveled periodically during the 1970's and currently are used for disposal of potato-processing wastewater. Prior to development of Jensen Grove Park and the Blackfoot golf course (fig. 1), historical flood plains and river channels southeast of the straightened channel were landfill sites ( $f$ ig. 4). Jensen Grove Lake was formed by excavating the former site of a large bend in the Snake River channel to obtain sand and gravel fill for construction of the interstate highway. The excavation depression later was contoured and presently is filled with excess canal water during late spring and summer months. Differences between pre-1960 and 1985 channels of the Snake River in the Groveland-Collins area are illustrated in figure 8 .

Except for the June 1976 flood resulting from the Teton Dam failure, there have been no major floods of the Snake River at Blackfoot since the 1956 completion of Palisades Dam upstream near the Idaho-Wyoming border. Lowlands adjacent to the river are flooded occasionally during periods of spring snowmelt runoff or heavy winter ice conditions. Along diked reaches of the river, high water levels during spring runoff cause boggy conditions in the interstate right-of-way and Jensen Grove Park but have little or no effect on land northwest of the river. High water resulting from winter ice dams on the river may cause local flooding on both sides of the diked reach if water breaches a part of the dike or backs up into relatively shallow irrigation canals, drains, and ditches.

Discharge records from the Snake River at Blackfoot gage $(0.25 \mathrm{mi}$ downstream from U.S. Highway 26 bridge) indicate that maximum river discharge is in May or June and minimum discharge is in september or October. The highest discharge recorded from August 1978 to 1985 was 28,600 $\mathrm{ft}^{3} / \mathrm{s}\left(1 \mathrm{ft}^{3} / \mathrm{s}=7.48 \mathrm{gal} / \mathrm{s}\right)$ on May 18,$1984 ;$ minimum discharge recorded was $92 \mathrm{ft}^{3} / \mathrm{s}$ on October 2, 1980 ; and average discharge for the period $1978-84$ was $6,301 \mathrm{ft}^{3} / \mathrm{s}$.

From October 1983 through September 1985, maximum discharge was $28,600 \mathrm{ft}^{3} / \mathrm{s}$ on May 18,1984 , and minimum discharge was $672 \mathrm{ft}^{3} / \mathrm{s}$ on July 4, 1985. Water-surface altitudes of the Snake River at the gaging station on these days were 4,472 ft and 4,465 ft (fig. 9). The hydrographs show highest and lowest altitudes for each year, total monthly precipitation, periods of ice damming, snowmelt or spring precipitation, and irrigation water withdrawals. 
2. 2.

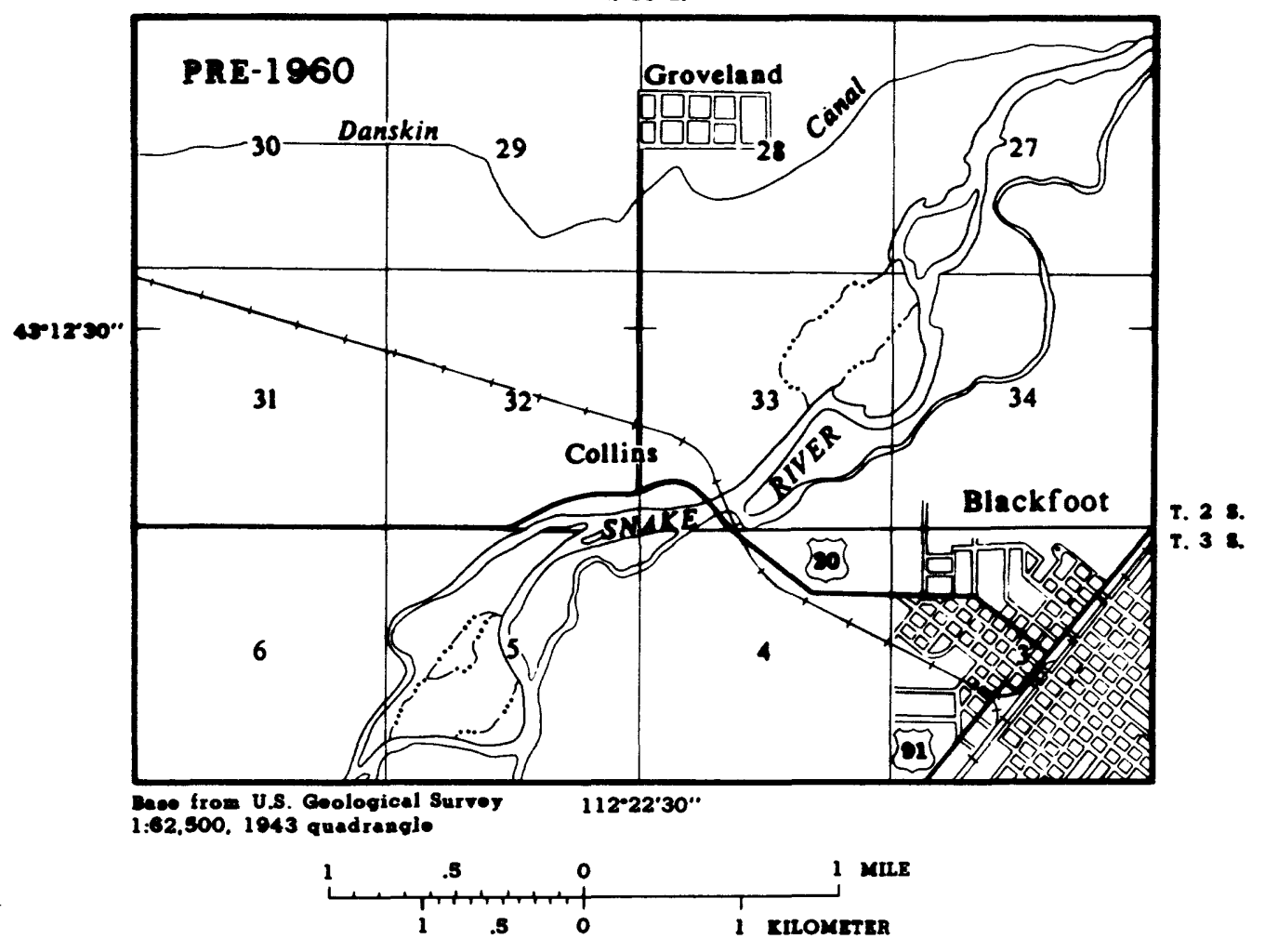

2. 352

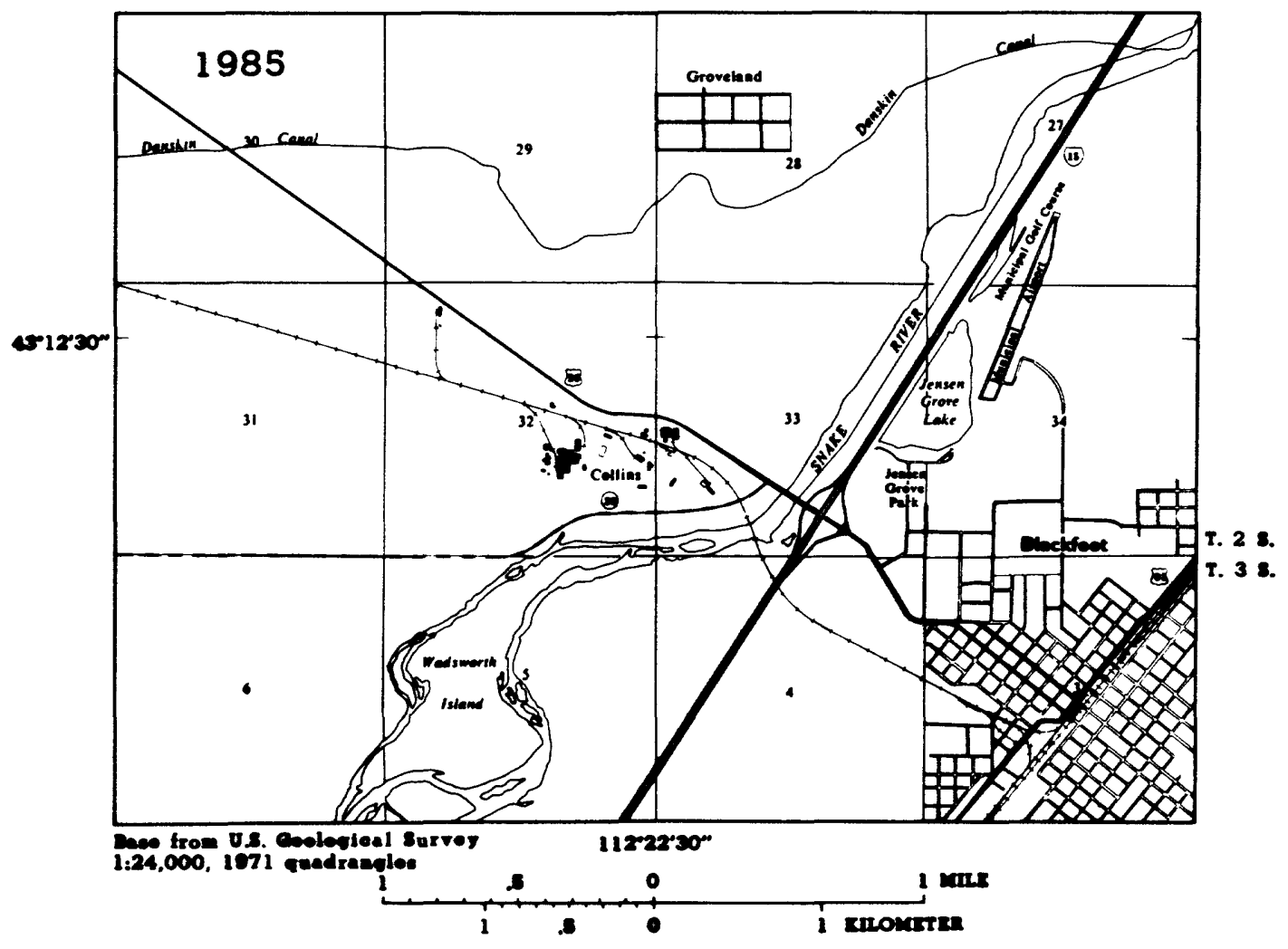

Figure 8.-Approximate beations of pre-1960 and 1985 channels of the Saake River. 

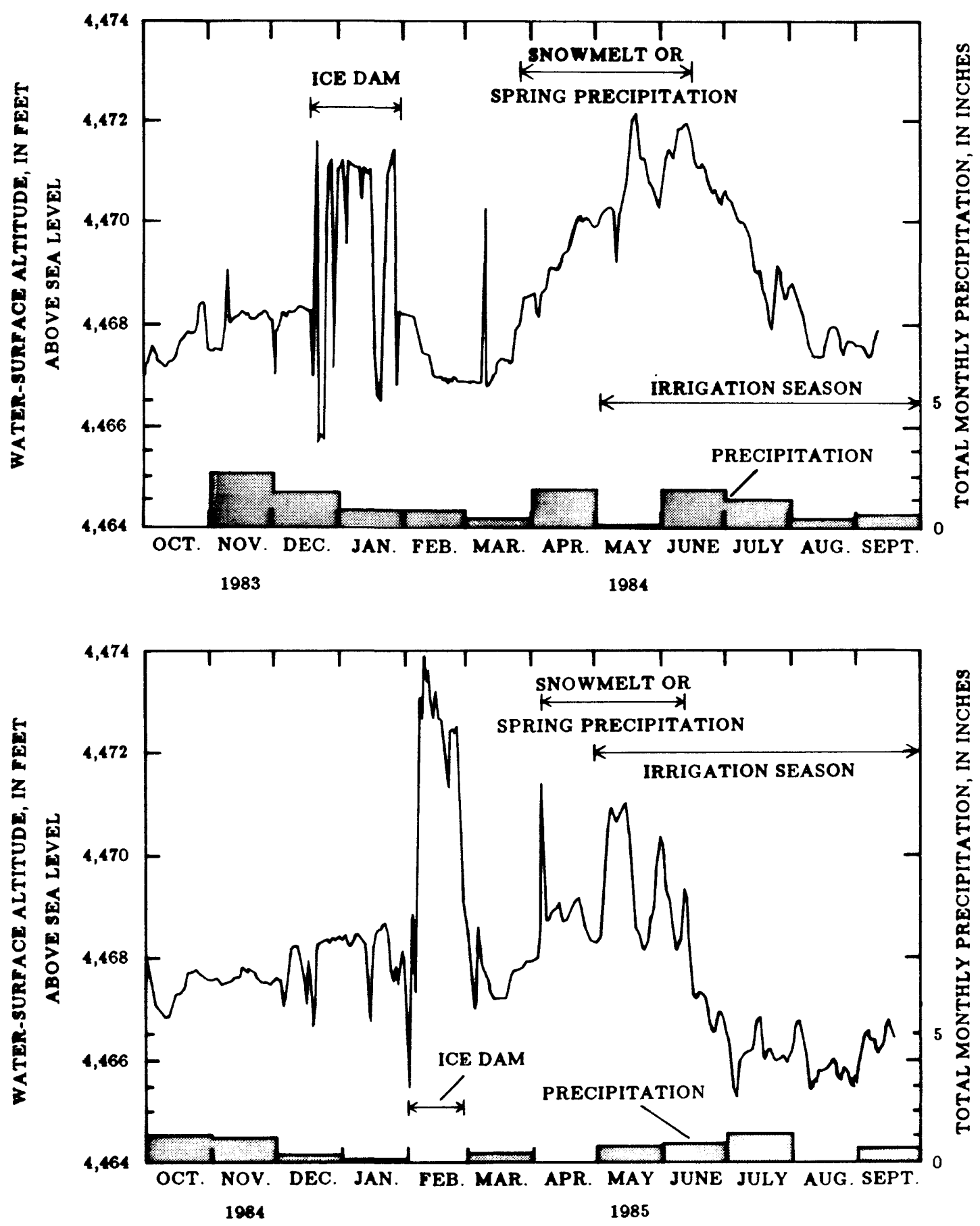

Figure 9.--Water-surface altitudes of the Snake River at Blackfoot and total monthly precipitation at Blackfoot, October 1983 to September 1985. 
Millions of gallons of water for irrigation are diverted from the Snake River each year into a complex network of canals, ditches, and sloughs (fig. 10). Watermaster records show that measurable discharge in the canals begins in late April or early May, peaks in June or July, and ends in late October or early November (Carlson, 1980-82). Approximate peak discharges in a few larger canals in the Groveland-Collins and surrounding areas during 1985 were (1) $1,180 \mathrm{ft}^{3} / \mathrm{s}$, Aberdeen-Springfield Canal; (2) $230 \mathrm{ft}^{3} / \mathrm{s}$, Danskin Canal; and (3) $260 \mathrm{ft}^{3} / \mathrm{s}$, Corbett Canal (R.C. Carlson, water District 01, written commun., 1985). Irrigation water supplied by canal networks or, to a minor extent, by ground water, is used on nearly all land in the Groveland-Collins and surrounding areas. Flood or sprinkler irrigation begins as soon as water is available in the spring and continues as long as water is available in the fall. Excess irrigation water returns to the Snake River by means of ditches and drains.

\section{Movement of Water Through Unsaturated Rock}

Much of the water moving through the first few feet of soil evaporates or is transpired by plants. Some of the water moves into unsaturated rock and adheres to grain surfaces; the remaining water continues to move downward and ultimately recharges the ground-water system. Water moving downward may encounter strata of clay or other fine-grained sediment of low hydraulic conductivity and may form saturated zones perched above the ground-water system. In general, perched water moves laterally along the upper surface of the fine-grained sediment until it is pumped from wells, is discharged as springs or to surface water sources, or, reaching the limits of the inhibiting strata, infiltrates to saturated rock.

Movement of water through soil and unsaturated rock is the primary means by which contaminants are introduced into water-yielding zones in the ground-water system. Idealized paths of water movement in unsaturated and saturated rock are shown in figure 11 .

In 1980, the Snake River from Shelley $23.5 \mathrm{mi}$ downstream to Blackfoot had an estimated net loss of 110,000 acre-ft of water ( 1 acre-ft = about 326,000 gal) to the ground-water system (L.C. Kjelstrom, U.S. Geological Survey, written commun., 1986). Prior to 1985, however, specific water loss or gain in the Snake River near Groveland and Collins had not been measured. The river was reported to be above the ground-water system, and the riverbed was reported to be tightly cemented or sealed, permitting little or no leakage (Bingham County, 1981, p. 14-17). 


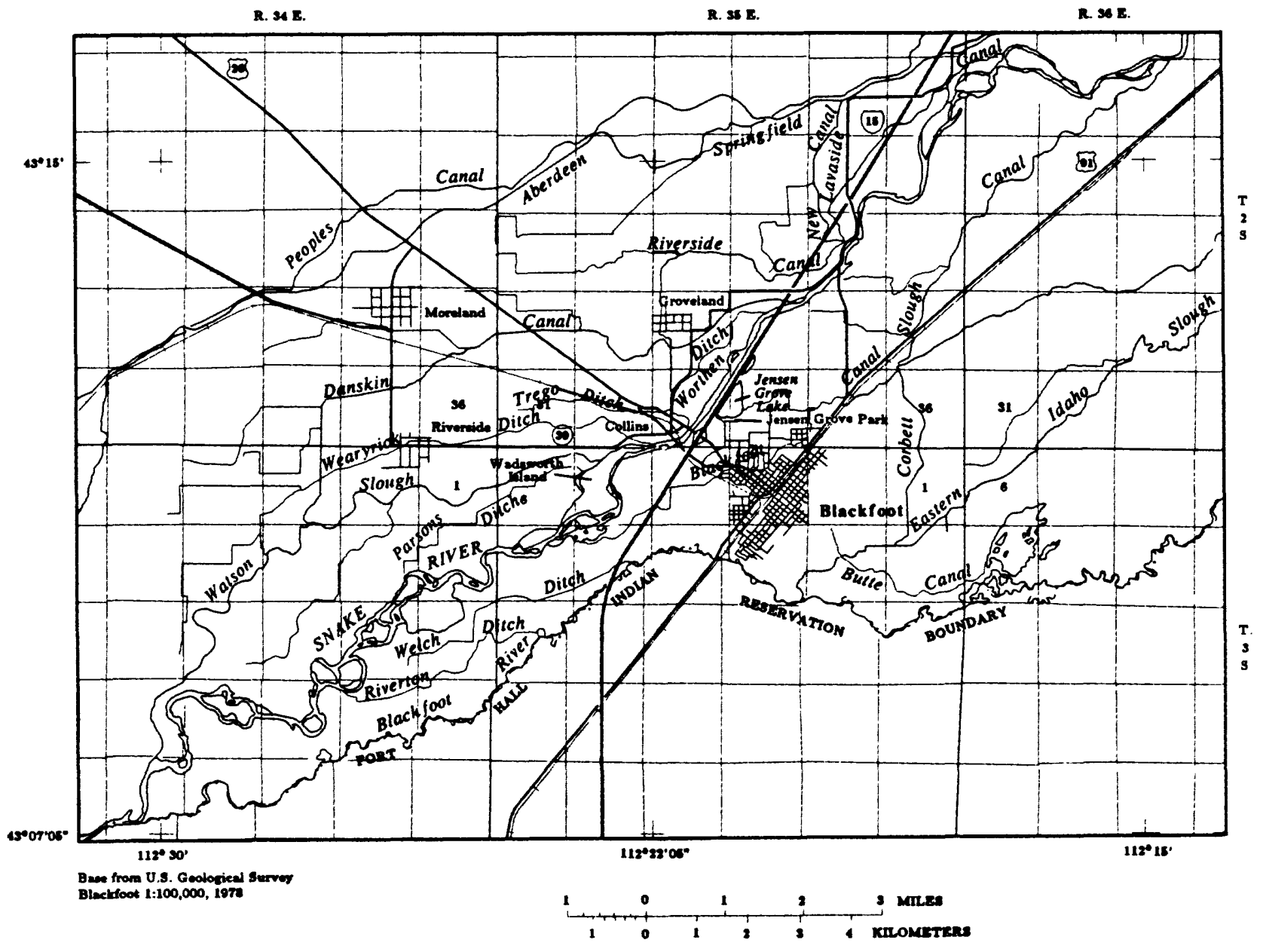

Figure 10.--Locations of selected canals, ditches, and sloughs. 
TRANSPIRATION

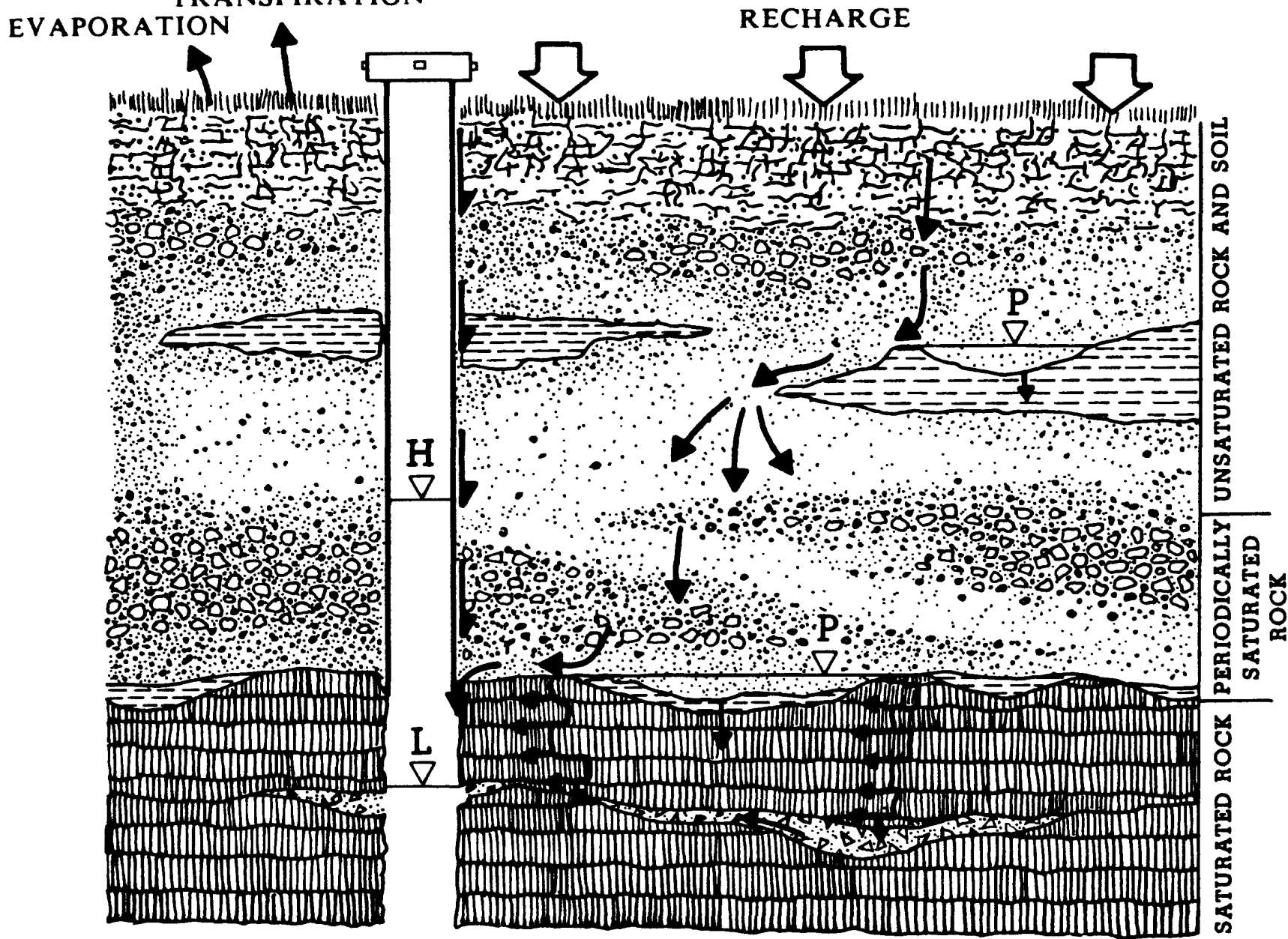

EXPLANATION

\begin{tabular}{|c|c|c|c|}
\hline 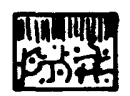 & SOIL & 8 & CINDERS, RUBBLY BASALT \\
\hline$\Leftrightarrow$ & $\begin{array}{l}\text { FINE TO COARSE SAND OR } \\
\text { SILTY SAND }\end{array}$ & $\nabla$ & $\begin{array}{l}\text { WATER LEVEL; P, PERCHED; } \\
\text { L, LOWEST ANNUAL WATER } \\
\text { LEVEL; H, HIGHEST ANNUAL }\end{array}$ \\
\hline \% & $\begin{array}{l}\text { COARSE SAND, GRAVEL, } \\
\text { COBBLES }\end{array}$ & & $\begin{array}{l}\text { WATER LEVEL } \\
\text { GENERALIZED DIRECTION OF } \\
\text { WATER MOVEMENT }\end{array}$ \\
\hline$E=-$ & CLAY OR SILT & & WELL CASING \\
\hline 曲地 & $\begin{array}{l}\text { FRACTURED, JOINTED } \\
\text { BASALT FLOWS }\end{array}$ & & \\
\hline
\end{tabular}

Figure 11.--Idealized paths of water movement in unsaturated and saturated rock. 
On July 29, 1985, two discharge measurements were made at each of three sites on the Snake River upstream from the U.S. Highway 26 bridge at Blackfoot: (1) Upper site, $1.95 \mathrm{mi}$ upstream; (2) middle site, $1.15 \mathrm{mi}$ upstream; and (3) lower site, $0.3 \mathrm{mi}$ upstream. During the measurements, no river water was diverted from and no surface water was discharged to the reach. Both wading and boat measurements were made.

\begin{tabular}{lccccc} 
& $\begin{array}{c}\text { Time, } \\
\text { first } \\
\text { measure- } \\
\text { ment } \\
\text { (p.m.) }\end{array}$ & $\begin{array}{c}\text { Discharge } \\
\left(\mathrm{ft}^{3} / \mathrm{s}\right)\end{array}$ & $\begin{array}{c}\text { Time, } \\
\text { second } \\
\text { measure- } \\
\text { ment } \\
\text { Site }\end{array}$ & $\begin{array}{c}\text { Discharge } \\
\left.\text { (ft }{ }^{3} / \mathrm{s}\right)\end{array}$ & $\begin{array}{c}\text { Average } \\
\text { discharge } \\
\text { measurement } \\
\text { (rounded) }\end{array}$ \\
\hline Upper & $12: 50-2: 30$ & 1,410 & $1: 00-2: 30$ & 1,370 & 1,390 \\
$\begin{array}{l}\text { Middle } \\
\text { Lower }\end{array}$ & $3: 26-4: 18$ & 1,430 & $3: 30-4: 18$ & 1,400 & 1,415 \\
$12: 30-1: 32$ & 1,570 & $12: 40-1: 42$ & 1,520 & 1,545
\end{tabular}

These figures show a net gain of about $160 \mathrm{ft}^{3} / \mathrm{s}$ (on the basis of the average measurement per site) between upper and lower sites but do not take into consideration individual measurement errors or evaporation losses. Even if figures could be adjusted to reflect all possible sources of error, some net gain in discharge from the upper to the lower site would remain.

The following observations about the relations between surface and subsurface water in the Groveland-Collins area are based on the July 1985 discharge measurements, 1ithologic information from drillers' logs, and ground-water level measurements made during 1984 and 1985:

1. The Snake River near Blackfoot is above the ground-water system but loses water to and gains water from perched water adjacent to the river. Water probably is exchanged through banks of the channel rather than through the streambed. Perched water moves northwestward laterally through historical river channel deposits. Losses and gains probably are relatively small, are localized in the channel, and change with varying water-surface altitudes. Net gain measured in the 1.95-mi reach above Blackfoot on July 29, 1985, was about $160 \mathrm{ft}^{3} / \mathrm{s}$.

2. Jensen Grove Lake is above the ground-water system. Although altitude of the lake bottom is below that of the nearby snake River streambed, the lake is filled primarily by diverted canal water, not by leakage from the snake River. When the canals are dry, the lake is dry. Occasionally, Snake River water is diverted to the lake by a gated ditch, but lake-surface altitudes 
fluctuate in response to changes in canal supply rather than to direct inflow from the river. Large volumes of water leak from the lake to underlying rock. Some leakage is perched above clayey sediment and moves northwestward laterally toward the river. Some of this perched water may discharge to the Snake River near the U.S. Highway 26 bridge.

3. Sloughs between Interstate Highway 15 and the river dike are filled primarily by leakage from the Snake River or direct inflow from either the Snake River or Jensen Grove Lake. Sloughs southeast of Interstate Highway 15 in Jensen Grove Park are remnants of the historical Snake River channel and probably are filled by leakage from both the Snake River and Jensen Grove Lake.

4. Canals and ditches are above the ground-water system and leak undetermined volumes of water. Large canals with high volumes of discharge and small amounts of finegrained sediment in the channels lose more water than canals with low discharge and accumulations of fine-grained sediment coating channel sides and beds. Channel losses were not measured but are reflected in ground-water levels in wells adjacent to canals and ditches. Discussions of canal seepage characteristics are included in reports by Netz (1980) and Herbert and others (1985).

\section{Ground Water}

In the Groveland-Collins and surrounding areas, the ground-water system is in basalt of the Snake River Group. Principal water-yielding zones are interbeds of cinders, rubble, and sediment, or joints and fractures in the basalt. Physical and structural character of the basalt, as individual flows and as a unit, is areally diverse, and configuration of the flow surface, fractures, joints, and nature of the interbeds significantly influence areal hydrology. Hydraulic characteristics of the water-yielding zones are highly variable and were not defined quantitatively in the study. Generalized hydraulic characteristics are described in table 1 and in several reports, including those by Mundorff and others (1964) and Castelin (1974).

Ground water in the basalt may be confined or unconfined. Water in fractures, joints, and interbeds immediately underlying coarse sedimentary deposits probably is unconfined. Fine-grained sediment overlying basalt, massive basalt flows, or fine-grained interbed deposits may cause confined conditions. During the drilling of well M5 
(fig. 2), for example, water first was encountered about $55 \mathrm{ft}$ below land surface, more than $30 \mathrm{ft}$ below the top of the basalt. Shortly after completion of drilling, the water level in the well rose about $27 \mathrm{ft}$. Except in rare instances, it is generally not possible to define confined or unconfined water-yielding zones. Exact information on depths to water-yielding zones most often is not included in drillers' logs, and the common well construction practice of uncased borehole in basalt allows mixing of water from all zones in the borehole.

Water levels in wells cased to and completed in basalt probably represent a mixture of confined and unconfined zones within the basalt, and maps of water-level contours for the area represent a potentiometric (equal pressure) surface rather than a water-table surface. Water-level contours for various periods in 1984 and 1985 are compared in figures 12 and 13 . Figure 12 shows generalized seasonal contours for the Groveland-Collins and surrounding areas during 1984. Figure 13 shows details of seasonal changes in water-level contours in the GrovelandCollins area during 1985. Direction of ground-water movement is indicated by arrows drawn perpendicular to waterlevel contours.

As shown in figures 12 and 13, ground water moves generally northwestward throughout the year, and contour patterns change most noticeably between spring and summer each year. Areas of particular interest include: (1) Water-level "mounds" (localized areas of unusually high water-level altitudes--fig. 12B, township 2 south, range 34 east, sections 14,23-24, and 29-30, for example) near major canals, which probably represent surface-water leakage through cobbly canal channels; (2) abrupt changes in water levels in wells near Jensen Grove Lake owing to lake leakage beginning with spring ground thaw and continuing throughout the irrigation season; (3) variations in contour patterns at Collins, particularly during winter and spring months. Some of these effects may be due to continuous, large-volume ground-water withdrawals for potato-processing operations in the area; and (4) the unusual northeastward pattern of ground-water movement and closely spaced contours in the spray field area (sections 28 and 33, fig. 13), probably where ground water moves around a prominent subsurface basalt ridge near wells 97 and 112 (figs. 6, 7D, and 7E). In the Jensen Grove Lake area, some water in the basalt moves northwestward under the Snake River.

Hydrographs of 1984-85 water-level altitudes for selected wells completed in basalt of the Snake River Group are presented in figures $14 \mathrm{~A}$ and $14 \mathrm{~B}$. Straight lines 

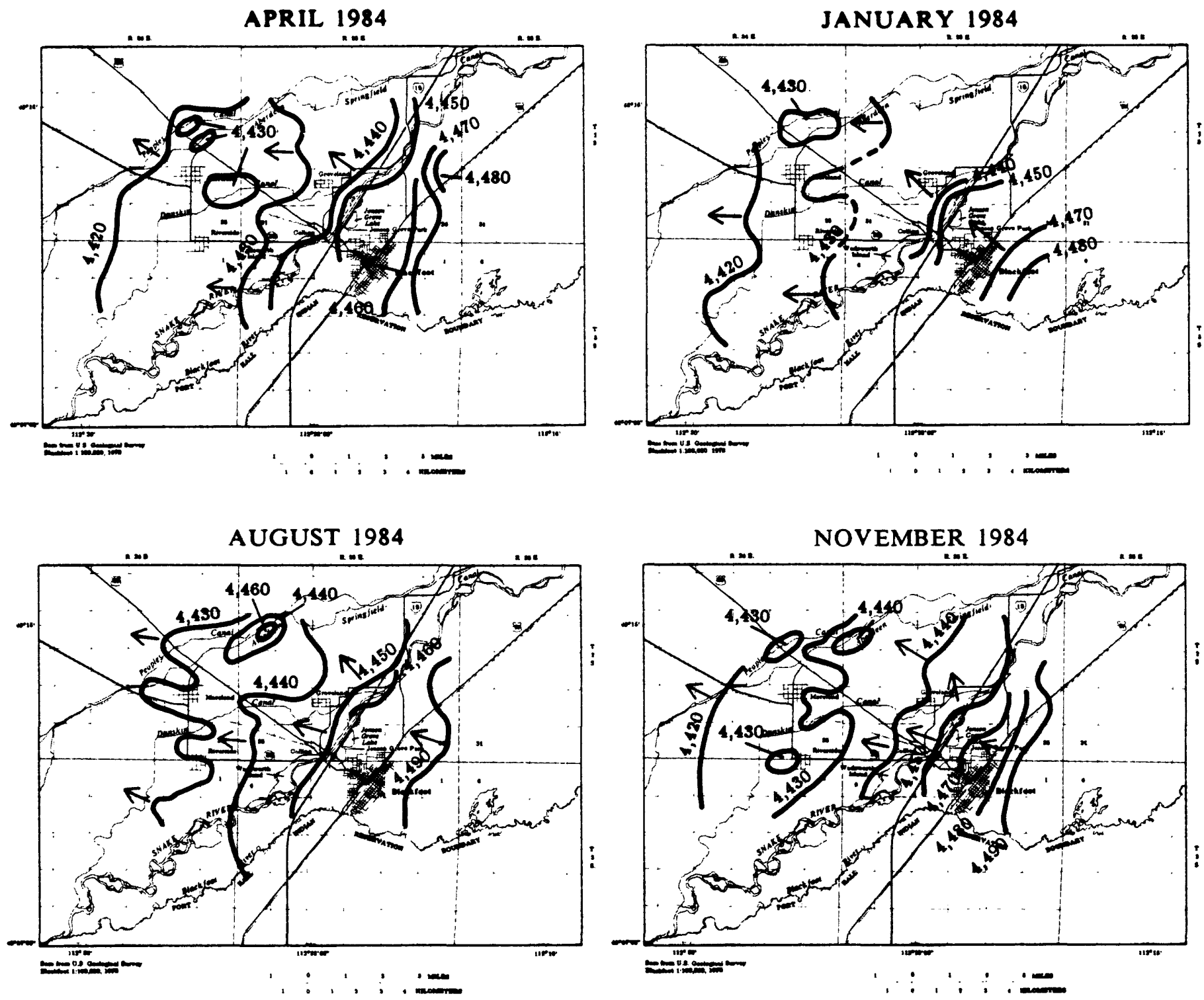

EXPLANATION

4,150 WATER-LEVEL CONTOUR--Shows altitude of water level,
in feet above sea level. Dashed where approximately
located. Contour intervals variable

Figure 12.--Water-level contours and generalized direction of ground-water movement, Groveland-Collins and surrounding areas, January to November 1984. 
APRIL 1985

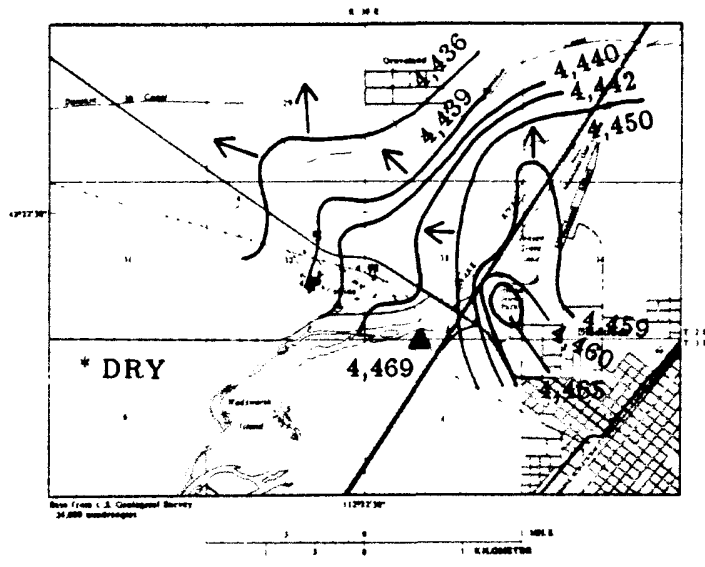

MAY 1985

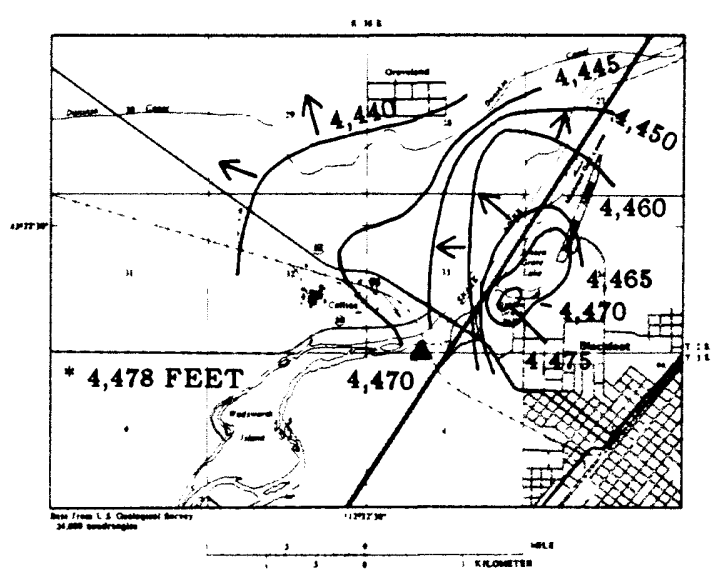

SEPTEMBER 1985

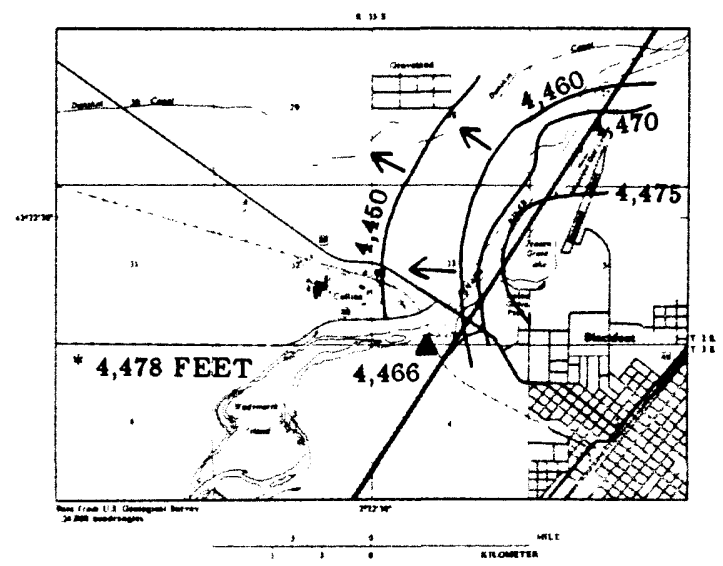

JANUARY 1985

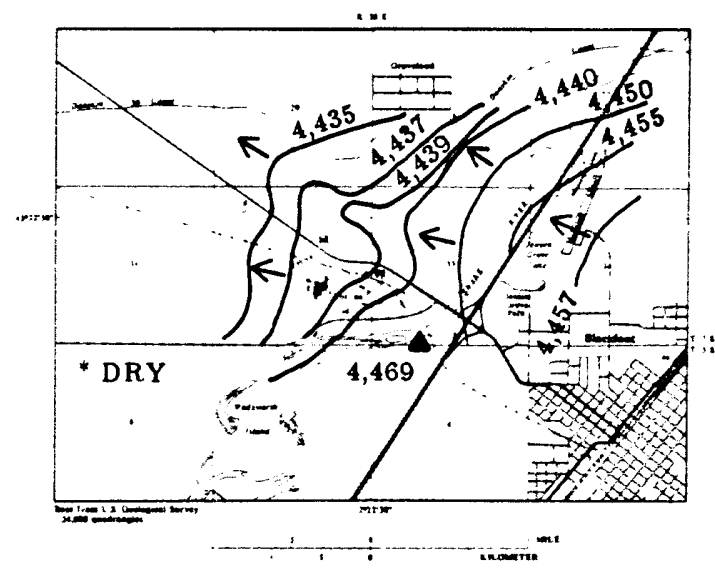

JUNE 1985

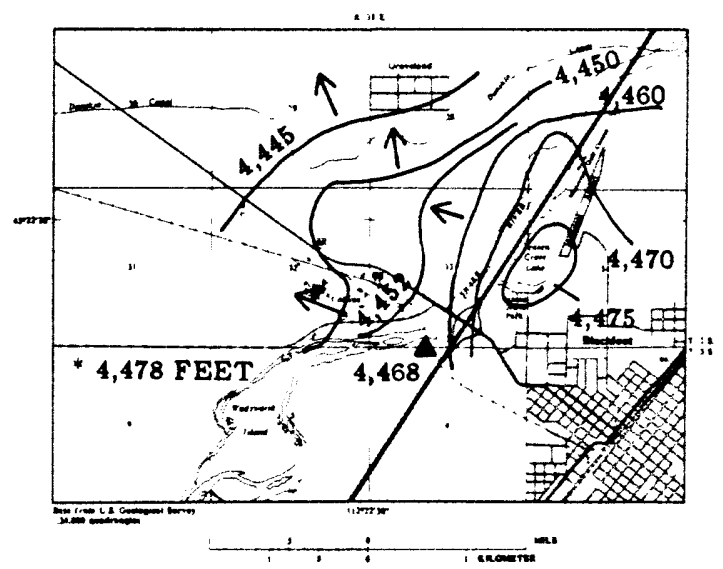

JULY 1985

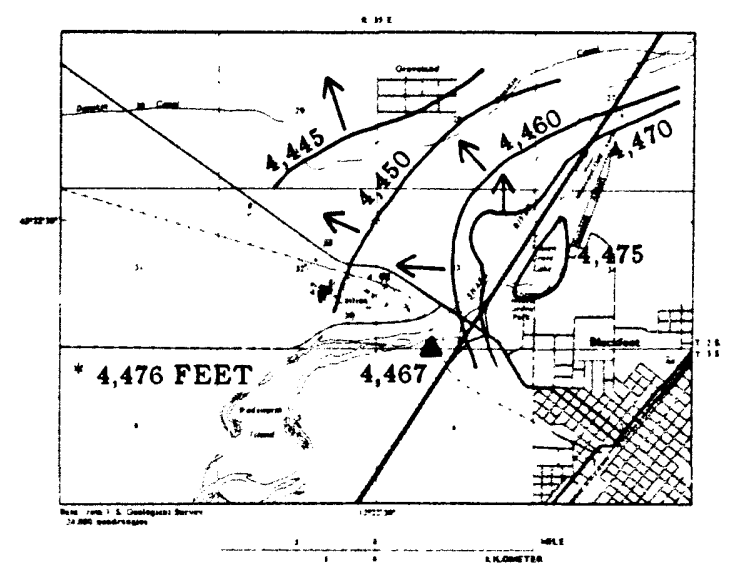

EXPLANATION

4,450 WATER-LEVEL, CONTOUR--Shows altitude of water level, in feet above sea level. Contour intervals variable

$\longrightarrow$ GENERALIZED DIRECTION OF GROUND-WATER MOVEMENT

* 4,478 FEET WATER-SURFACE ALTITUDE OF JENSEN GROVE LAKE, IN FEET ABOVE SEA LEVEL

$4,466 \triangle$ WATER-SURFACE ALTITUDE OF SNAKE RIVER, IN FEET ABOVE SEA LEVEL

Figure 13.--Water-level contours and generalized direction of ground-water movement.

Groveland-Collins area, January to September 1985. 


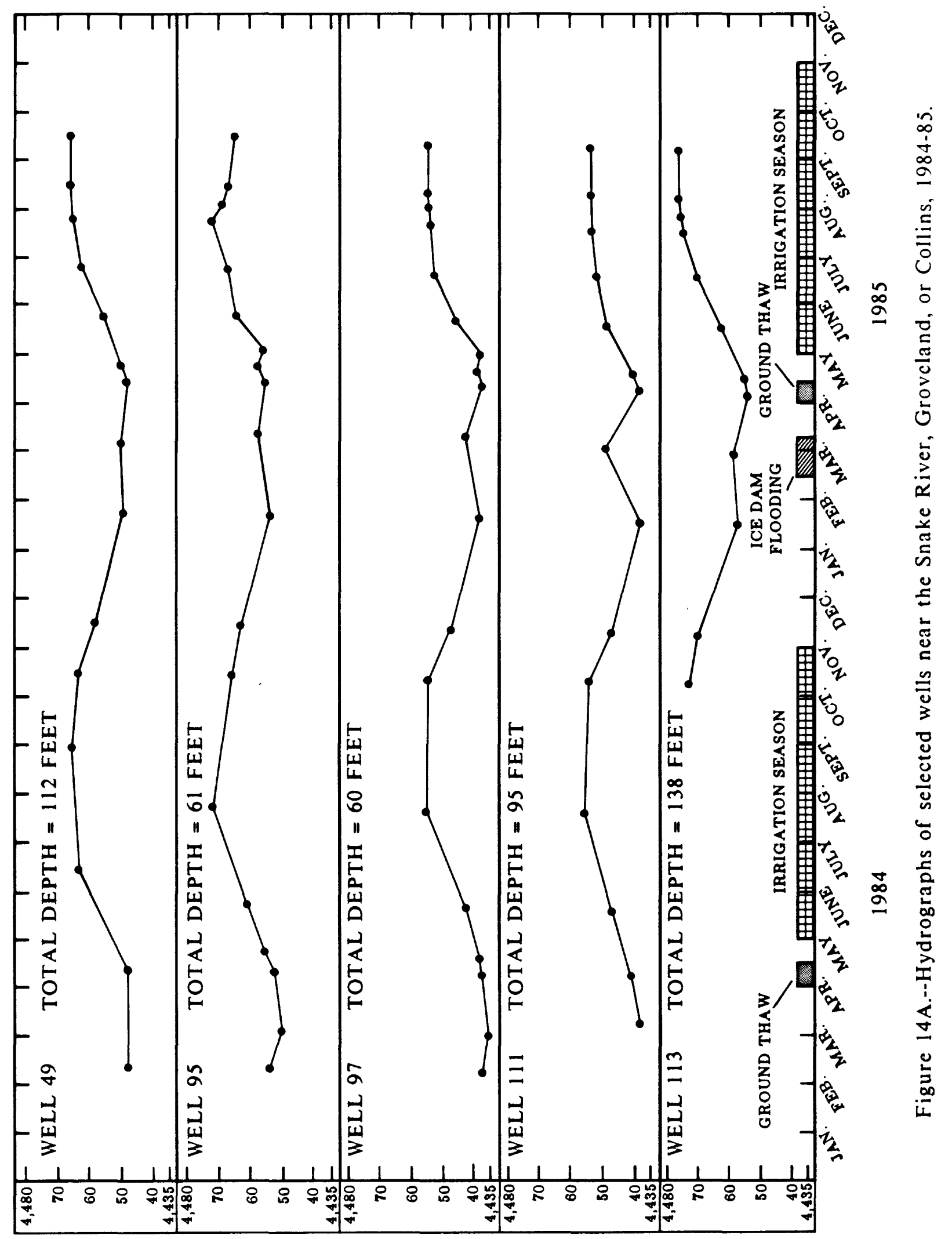

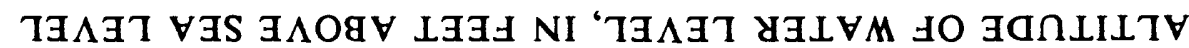




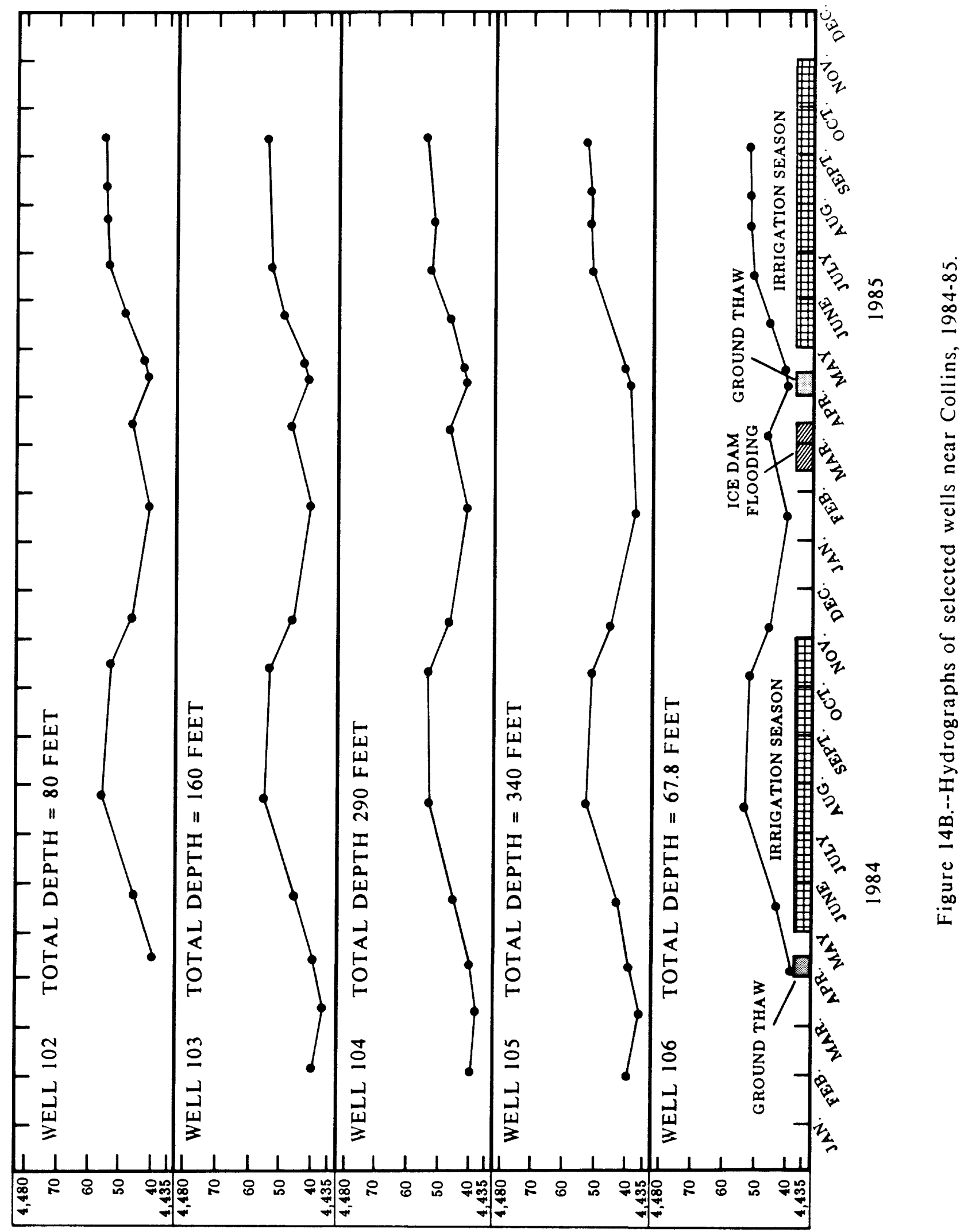

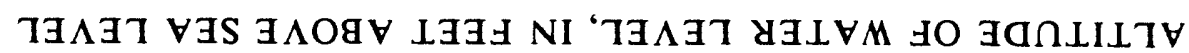


between data points in these figures do not represent constant rates of water-level increase or decline. Water levels are in a state of continual change and may have risen or declined between measurements.

Hydrographs presented in figure l4A are from wells near the Snake River, Groveland, or Collins. Depths of the wells range from $60 \mathrm{ft}$ to $138 \mathrm{ft}$ below land surface. Patterns of water-level altitudes are similar in most wells, but amplitude of water-level responses to hydraulic conditions such as river stage and ice dam flooding is different.

Little information is available on the vertical movement of water between water-yielding zones in basalt of the Snake River Group. Hydrographs in figure $14 \mathrm{~B}$ are from wells in a relatively small area near collins at depths between about $68 \mathrm{ft}$ and $340 \mathrm{ft}$ below land surface. Wells 104 and 105 ( $290 \mathrm{ft}$ and $340 \mathrm{ft}$ deep) and nearby wells 106,102 , and 103 (about 68,80 , and $160 \mathrm{ft}$ deep) show slight local differences in water-level altitudes between water-yielding zones at different depths. Patterns of response to landsurface conditions such as local recharge are similar for all five wells and may indicate that water-yielding zones in the basalt are interconnected. Water-quality characteristics may be distinctly different for water from deep or near-surface basalt flows, however (see section, "WaterQuality Data").

Recharge to the ground-water system is primarily from leakage or infiltration of surface water, applied irrigation water, and precipitation. Most recharge is from leakage of surface water and infiltration of irrigation water. Data from wells in the Groveland-Collins and surrounding areas show that water levels begin to rise soon after the irrigation season begins (late April or early May), are generally highest in July or August during peak irrigation water applications, and decline after the irrigation season ends in October (Parliman, 1986, table 1 ; figures $14 \mathrm{~A}$ and 14B).

Precipitation is a particularly significant source of ground-water recharge from late March to May. Thawing soils permit infiltration of large quantities of snowmelt, and ground-thaw recharge is evident on water-level hydrographs of wells 95 and 97 during April 1985 ( $f$ ig. 14A). Periods of ground-thaw recharge are especially important to the mobilization and movement of some surface or near-surface contaminants to the unsaturated or saturated zone (see section, "Water-Quality Data").

Dry canals and frozen soils in late fall and winter months reduce or eliminate most recharge, and ground-water levels normally are lowest in late January or February. In 
mid-winter, however, ice dam conditions may result in significant subsurface recharge. For example, in midFebruary 1985, ice dams near the U.S. Highway 26 bridge at Collins caused high water to breach the northwest dike, and floodwater backed up into drain canals and adjacent low-lying fields. The ice dam and high water conditions continued into early March 1985, and low-lying fields remained flooded until ground thaw in late March. These unusual surface conditions created a temporary, localized recharge mound in the area, evident in hydrographs (figs. $14 \mathrm{~A}$ and 14B). The effect is most pronounced in the hydrograph for well 111 , and recharge effects are attenuated with distance from the flooded area (fig. $14 \mathrm{~A}$, wells 49 and 113 , for example). Recharge was suspected to have been from river and canal leakage, rather than seepage from the flooded fields, because recharge effects decreased as soon as water levels declined in the river and canals, even though fields remained flooded.

Reports by local residents of water "disappearing into holes" in ditch channels, particularly in the Groveland area, could not be verified during this study; however, such incidents may be possible if the fractured basalt surface is near land surface. In some locations in the Groveland area, drillers' logs report basalt at about 5 ft below land surface.

Channel losses in the irrigation canal network were not measured or estimated in the Groveland-Collins and surrounding areas; however, recharge from canal leakage is evident, as indicated by water-level mounds in figure 12 (sections $14,23-24$, and 25, township 2 south, range 34 east) and by significant changes in water levels in some wells when water is first released to the canals. For example, well 33 (fig. 2) is adjacent to the AberdeenSpringfield Canal and had at least a 13-ft increase in water-level altitude (dry hole to $13 \mathrm{ft}$ of water in the well) within 2 weeks of water first entering the canal (Parliman, 1986). Unlined canals and ditches with beds of cobbles, pebbles, and coarse sand or that are constructed on exposed basalt may leak relatively large volumes of water annually to the subsurface. Where channel beds and sides are coated with accumulations of fine sediments, leakage is probably small, and recharge from these sources is masked by the large areal water-level changes. Discussions of various aspects of canal seepage are included in reports by Netz (1980), Gill (1984), and Herbert and others (1985).

In the Groveland-Collins and surrounding areas, annual water-level fluctuations may exceed 20 ft but commonly are $15 \mathrm{ft}$ or less. Areally extensive, relatively large seasonal changes in water levels are caused primarily by leakage and infiltration of surface and irrigation water. Infiltration of large volumes of water is important to ground-water 
quality in the area because percolating water transports contaminants to unsaturated rock and water-yielding zones in basalt. Also, contaminants that normally would not infiltrate through the entire thickness of unsaturated rock may be flushed periodically from sediments overlying basalt by rising water levels. Figures $15 \mathrm{~A}$ and $15 \mathrm{~B}$ show examples of the relations between fluctuating water levels and geologic, hydrologic, and well construction conditions for wells located within about $0.5 \mathrm{mi}^{2}$ near Groveland, Collins, and the Snake River. Although annual trends of water-level altitudes for each of these wells are similar, regardless of total well depth, cased interval, or lithology, the relations of water level to cased interval, basalt surface, and period of saturated sediment are distinctly different.

\section{GROUND-WATER QUALITY IN THE GROVELAND-COLLINS AREA,} 1984 AND 1985

Variability in chemical and physical characteristics of ground water in the study area is due to many factors: (1) Geochemical properties, such as solubility and exchange characteristics of soil and rock; (2) mixing of water from different water-yielding zones; (3) contact time of water with soil and rock; (4) mineral composition of soil and rock; (5) relative proximity of the sampling site to source(s) of ground-water recharge; and (6) influences of man's activities, such as land- and water-use practices. Factors affecting water quality are discussed in detail in many texts, including those by Krauskopf (1967), Buckman and Brady (1969), Freeze and Cherry (1979), and Drever (1982).

The influence of man's activities on quality of recharge water may result in pronounced local changes in ground-water quality, sometimes over relatively short periods of time. Seventeen specific activities have been identified as potential sources of ground-water contamination in southern Idaho (Idaho Department of Health and Welfare, 1985, p. 48), and characteristic contaminants that may be associated with some of these land- and water-use practices (fig. 4) are listed in table 2. Additional information on the characteristics of selected land-use contaminants 1 isted in table 2 is given in reports by Whitehead (1974), Smith and others (1977), Freeze and Cherry (1979), Kelling and Peterson (1981), Burr (1983), and Canter and $\operatorname{Knox}(1985)$.

\section{Temporal Variation in water-Quality Characteristics}

Any chemical analysis of a water sample represents the quality of water in a small part of a water-yielding zone at a particular instant in time. Concentrations of major, 

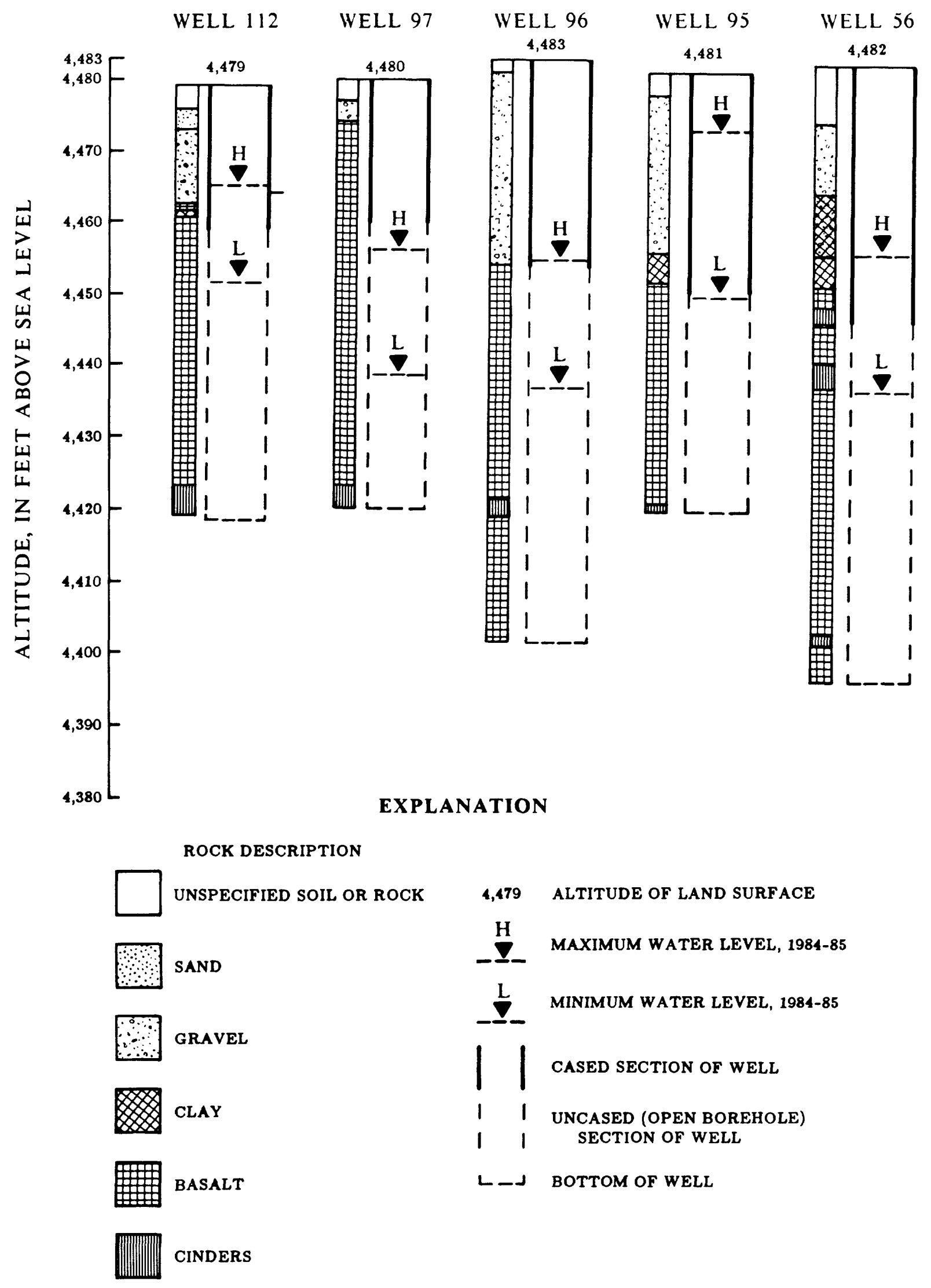

Figure 15A.--Relations of water-level fluctuations to well construction and subsurface rock, 1984-85. 


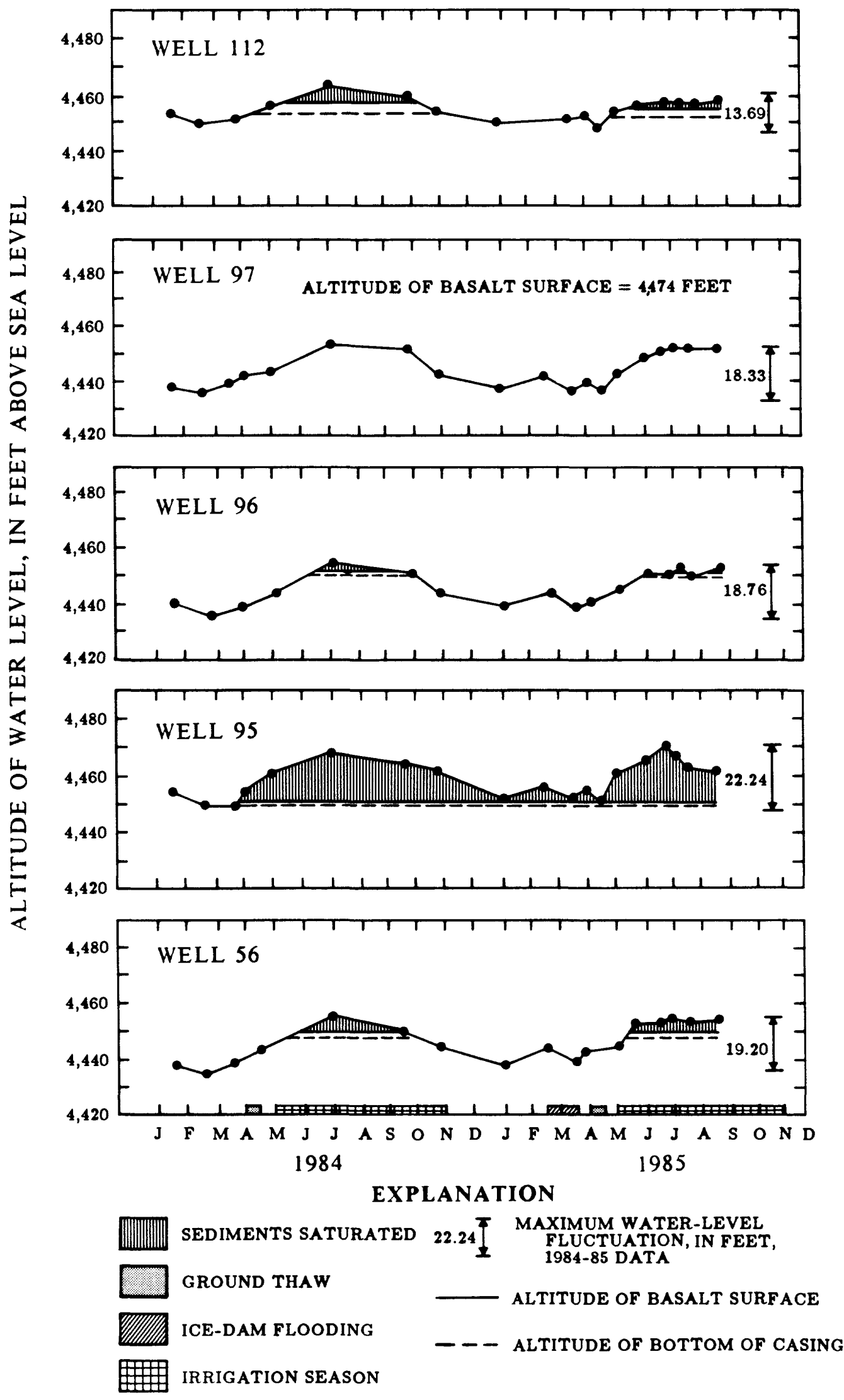

Figurc 15B.--Relations of water-level altitudes to basalt surface and period of saturated sediment, 1984-85. 
Table 2.--Characteristic contaminants associated with selected land- and water-use practices

Agriculture, irrigation runoff, crop and animal production, pavement or commercial yard runoff

Landfilis and dumps

Septic-tank soilpercolation systems, wastewater lagoons

Food-processing wastewater, land application
Total, suspended, and dissolved solids, fertilizers (chiefly nitrogen and phosphorus compounds and potassium), pesticides, organic compounds (nitrogen and carbon), sulfate, chloride, bicarbonate, trace elements, bacteria

Dissolved solids, major cations, major anions, organic compounds, methane, carbon dioxide, nitrogen and phosphorus compounds, toxic metal compounds, bacteria

Dissolved solids, bicarbonate, sodium, chloride, sulfate, nitrogen and phosphorus compounds, detergents, organic compounds, boron and other trace elements, bacteria

High chemical- and biologicaloxygen demand, total solids, suspended and dissolved solids, calcium, magnesium, sodium, potassium, sulfate, chloride, nitrogen and phosphate compounds, iron, manganese, dissolved suspended organic compounds (protein, fats, carbohydrates), bacteria 
minor, and trace inorganic constituents in ground water are controlled by numerous factors, including (1) availability of elements in the soil and rock through which the water moves, (2) the sequence in which subsurface water comes in contact with soil and rock, (3) rates of geochemical and biochemical processes, and (4) influences of land-and water-use activities on all the above. Quality of ground water is not constant, and a comparison of current and historical data for a particular sampling site may show temporal changes in one or more quality characteristics. Trends may show either improvement or degradation of water quality but, in most instances, reflect the effects of changing land- and water-use practices.

\section{Suitability of Water for Use}

Chemical, physical, and biological characteristics of water determine its suitability for use. Principal consumptive uses of ground water in the study area are for domestic, commercial, public, irrigation, and livestock supplies. Drinking water regulations determined by the EPA (U.S. Environmental Protection Agency, 1982a, 1982b), describe legally established mandatory and recommended limits for chemical constituents and physical properties for public water supplies. Local natural conditions, esthetic or economic considerations, and resource protection considerations may result in variation of the regulations in different areas. Although Federal drinking water regulations legally apply only to public water supplies, regulation limits provide a comparative base in water-quality discussion for all water uses. Source and significance of selected water-quality characteristics commonly important to domestic, commercial, public supply, and agricultural water users are presented in table 3. Regulations for selected water-quality characteristics commonly important to water users are included in table 3 .

Ground water in the study area is generally suitable for most uses. In parts of the study area, however, ground water contains chemical constituents or bacterial concentrations that could restrict the water's use. Although no public water supply limits have been established for alkalinity or hardness, high alkalinity, hard water, or highly mineralized water in some areas may be esthetically or economically restrictive. Nitrite plus nitrate as nitrogen concentrations exceed the maximum public drinking water limit of $10 \mathrm{mg} / \mathrm{L}$ (as nitrogen) in a few analyses and are anomalously high in several samples from the area. In a few places, concentrations of dissolved iron and manganese exceed public drinking water limits of $300 \mu \mathrm{g} / \mathrm{L} \mathrm{Fe}$ and $50 \mu \mathrm{g} / \mathrm{L} \mathrm{Mn}$, and dissolved $\mathrm{zinc}$ concentrations are anomalously high. Coliform bacteria concentrations exceed public drinking water limits in some areas (Parliman, $1986)$. 
Table 3.--Source and significance of selected water-quality characteristics

[mg/L, milligrams per liter; $\mu \mathrm{g} / \mathrm{L}$ micrograms per liter]

$\begin{array}{lll}\text { Characteristics } & \text { Source } & \text { Significance }\end{array}$

Specific conductance

Dissolved solids (calculated sum or residue on evaporation)

Temperature $\left({ }^{\circ} \mathrm{C}\right)$

pH

Alkalinity as calcium carbonate $\left(\mathrm{CaCO}_{3}\right)$

Bicarbonate $\left(\mathrm{HCO}_{3}\right)$

Carbonate $\left(\mathrm{OO}_{3}\right)$

Carbon dioxide $\left(\infty_{2}\right)$

Hardness as calcium carbonate $\left(\mathrm{CaCO}_{3}\right)$

Calcium (Ca), Magnesium (Mg)
An indicator of dissolved mineral content of water.

Mineral constituents dissolved from rocks and soils.

Variations may be due to deeper water circulation, thermal activity, seasonal air temperature variation, or disposal of surface wastewater.

Hydrogen-ion concentration.

Nearly all produced by dissolution of bicarbonate and carbonate.

Action of carbon dioxide in water on carbonate cementing material and rocks, such as limestone, dolomite, and travertine.

In most waters, nearly all hardness is due to calcium and magnesium.

Dissolved from practically all soils and rocks, but especially from limestone, dolomite, and gypsum.
A measure of the capacity of the water to conduct a current of electricity, and varies with the concentration and degree of ionization of different minerals in solution; the more dissolved minerals, the larger the specific conductance.

Water containing more than $1,000 \mathrm{mg} / \mathrm{L}$ of dissolved solids is unsuitable for many purposes. Recommended maximum limit for public water supplies is $500 \mathrm{mg} / \mathrm{L}^{1}$.

Affects the usefulness of water for many purposes. Temperature may affect palatability of water, solubility of chemical constituents, and coagulation, sedimentation, filtration. or chlorination processes.

A pH of 7.0 indicates neutrality of a solution. Values higher than 7.0 denote increased alkalinity; values lower than 7.0 indicate increased acidity. Corrosiveness of water generally increases with decreasing $\mathrm{pH}$, but excessively alkaline water also may be corrosive. Recommended level for public water supplies ranges from 6.5 to $8.0^{2}$.

Measure of water's capacity to neutralize acids. May produce objectionable taste.

Produce alkalinity. When heated in the presence of calcium and magnesium, can form scales in pipes and release corrosive carbon-dioxide gas. Aid in coagulation for the removal of suspended matter from water.

Soap-consuming capacity of a water. Forms white scales in teakettles and plumbing and $r$ ings in bathtubs. Although hardness is less of a factor with synthetic detergents than with soap, it is sometimes desirable to soften hard water for esthetic as well as economic reasons.

Causes most of the hardness in water. Calcium and magnesium combine with bicarbonate, carbonate, sulfate, and silica to form heatretarding, pipe-clogging scales in boilers and in other heat-exchange equipment. A high concentration of magnesium has a laxative effect, especially on new users of the supply. 
Table 3.--Source and significance of selected water-quality characteristics--Cont inued

Characteristics

sodium (Na),

Potassium (K)

Fluoride (F)

Chloride (CI)

Sulfate $\left(\mathrm{SO}_{4}\right)$

Silica $\left(\mathrm{SiO}_{2}\right)$

Nitrite $\left(\mathrm{NO}_{2}\right)$ plus

nitrate $\left(\mathrm{NO}_{3}\right)$ as

nitrogen $(\mathrm{N})$

Phosphorus (P, total)
Source

Significance
Dissolved from practically all rocks and soils, especially feldspars, clay minerals, and evaporites. Present in sewage and commercial fertilizers.

Dissolved in small quantities from most rocks and soils. Added to many public supplies.

Dissolved from rocks and soils. Present in sewage and industrial wastes.

Dissolved from rocks and soils containing gypsum, sulfides, and other sulfur compounds. May be derived from industrial wastes, both liquid and atmospheric.

Dissolved from practically all rocks and soils.

Atmosphere, legumes, plant debris, animal excrement, nitrogenous fertilizer in soil, and sewage.

Dissolved from many rocks and minerals, particularly apatite. Phosphate fertilizers and sodium phosphate in detergents (component of sewage) may be pollution sources of phosphorus.
More than $50 \mathrm{mg} / \mathrm{L}$ sodium and potassium in the presence of suspended matter causes foam in boilers, which accelerates scale formation and corrosion. Dissolved sodium concentrations may be important to those on sodium-restricted diets.

Fluoride concentrations in limited amounts have beneficial effects on the structure and resistance to decay of children's teeth. Excessive concentrations produce objectionable dental fluorosis (tooth mottling). Optimum recommended limits for public water supplies range from 1.4 to $2.4 \mathrm{mg} / \mathrm{L}$ and are based on annual average maximum daily air temperatures $^{2}$.

A salty taste can be detected when $\infty$ ncentrations exceed $100 \mathrm{mg} / \mathrm{L}$. In large quantities, increases the corrosiveness of water. Present available removal methods not generally economical for most uses. Recommended maximum limit for public water supplies is $250 \mathrm{mg} / \mathrm{L}^{1}$.

Sulfate in water containing calcium forms hard scales in steam boilers. In large amounts, sulfate, in combination with other ions, imparts bitter taste to water. Some calcium sulfate is considered beneficial in brewing processes. Recommended maximum limit for public water supplies is $250 \mathrm{mg} / \mathrm{L}^{1}$.

Together with calcium and magnesium, silica forms a low heat-conducting, hard, glassy scale in boilers and turbines. Silica inhibits deterioration of zeolite-type water softeners and corrosion of iron pipes by soft $\left(0-75 \mathrm{mg} / \mathrm{L} \mathrm{CaCO}_{3}\right)$ water.

Small amounts help reduce cracking of highpressure boiler steel. Encourages growth of algae and other organisms that produce undesirable taste and odors. Mandatory maximum limit for public water supplies is 10 $\mathrm{mg} / \mathrm{L}^{2}$.

One of the major nutrients required for plant nutrition and is essential for Iife. May indicate organic contamination. 
Table 3.--Source and significance of selected water-quality characteristics--Continued

$\begin{array}{lll}\text { Characteristics } & \text { Source } & \text { Significance }\end{array}$

Iron ( $\mathrm{Fe})$

Manganese $(\mathrm{Mn})$

Zinc $(\mathrm{zn})$
Dissolved from practically all rocks and soils, especially igneous and sedimentary rocks. Also caused by corrosion of pipes, pumps, and other cast iron or steel equipment or the presence of iron bacteria.

Occurs in various salts and minerals in nature, frequently in association with iron compounds.

Common mineral of ten associated with sulfides of other metals, especially lead, copper, cadmium, and iron. May be dissolved from galvanized pipe.
When concentrations are more than $100 \mu \mathrm{g} / \mathrm{L}$, iron cormonly precipitates on exposure to air, causing turbidity; stains plumbing fixtures and laundry; and results in tastes and colors objectionable in food and beverages. Recommended maximum limit for public water supplies is $300 \mu \mathrm{g} / \mathrm{L}^{2}$.

A micronutrient vital for plants and animals. Rarely toxic. Concentrations in excess of $50 \mu \mathrm{g} / \mathrm{L}$ may produce objectionable esthetic qualities similar to iron and sometimes intensified by the presence of iron. Recommended maximum limit for public water supplies is $50 \mu \mathrm{g} / \mathrm{L}^{2}$.

Essential to human metabolism. More than $5,000 \mu \mathrm{g} / \mathrm{L}$ produces a bitter, metallic, or astringent taste. Recommended maximum limit for public water supplies is $5,000 \mu \mathrm{g} / \mathrm{L}^{1}$.

'U.S. Environmental Protection Agency (1982b).

2U.S. Environmental Protection Agency (1982a). 
Where concentrations of chemical constituents exceed regulation limits or are esthetically or economically undesirable, it may be possible to reduce, remove, or control concentrations through appropriate water-treatment processes. Some methods for treating water are discussed in reports by Nordell (1961) and stacha and Pontius (1984).

\section{Water-Quality Data}

Water-quality data for all wells sampled in 1984 and 1985 were compiled by Parliman (1986). Statistical summaries by $90 t h, 75 t h$, and $50 t h$ (median) percentiles, and range of values for all 1984 and 1985 water-chemistry data were used to summarize and compare the large volume of data. These selected statistics, together with the total number of samples for each characteristic, are shown in table 4. Mean (average) values also are included in table 4 for reference. Large differences between the median and mean for a constituent indicate that the total number of samples for that constituent includes comparatively high concentration values, perhaps owing to localized contamination.

With the exception of dissolved oxygen, the upper 25 percent of water-quality data values (total number of samples), or 75 th to looth percentiles, are anomalous concentrations and are the primary focus of water-quality discussion in this report. The primary focus of the discussion of dissolved oxygen is the lower 25 percent of the total number of samples, or 0 to 25 th percentiles. Analyses (1984-85 data) of water from wells with anomalous concentrations of selected constituents are presented in table 5 . Only those wells with at least one anomalous concentration are 1 isted within each constituent category in table 5 but, for temporal trend and data comparison purposes, all values are shown for each well in each category.

Areal distribution of 10 water-quality constituents during May 1984 is shown in figures 16A-16C. Analyses from selected wells are grouped by general area, from Groveland southwestward to Wadsworth Island (fig. 2).

\section{Cations and Anions}

Major cation components of ground water (generally greater than $10 \mathrm{mg} / \mathrm{L}$ ) include dissolved calcium, magnesium, and sodium. Minor (generally $0.01-10 \mathrm{mg} / L$ ) and trace (less than $0.01 \mathrm{mg} / \mathrm{L}$ ) cation components of importance to study area ground water are dissolved potassium, ammonium, iron, manganese, and zinc. Concentrations of most cation components are usually low, less than $16 \mathrm{mg} / \mathrm{L}$, and are not a problem to water users. Where anomalously high, cation concentrations may contribute to highly mineralized or hard water. 


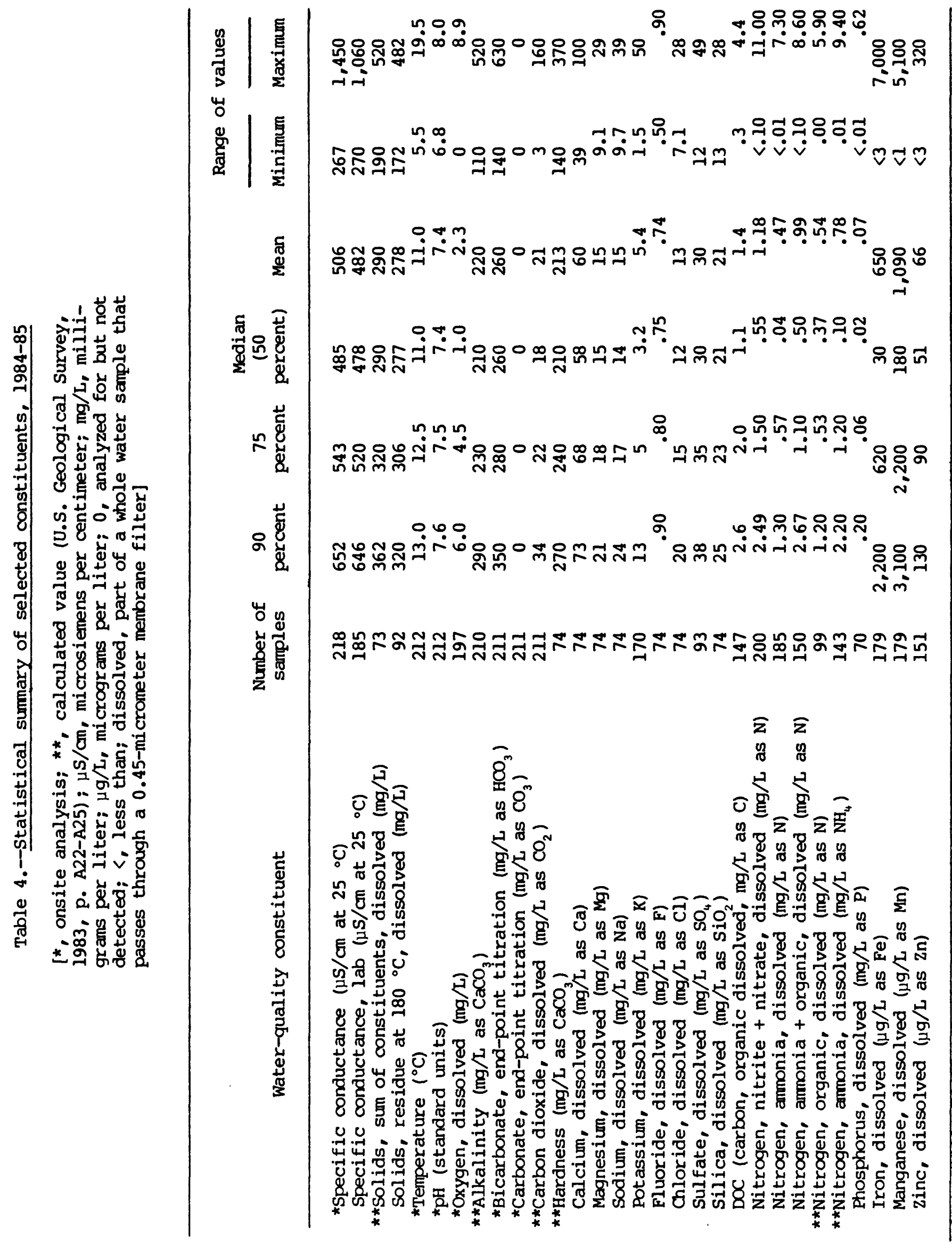




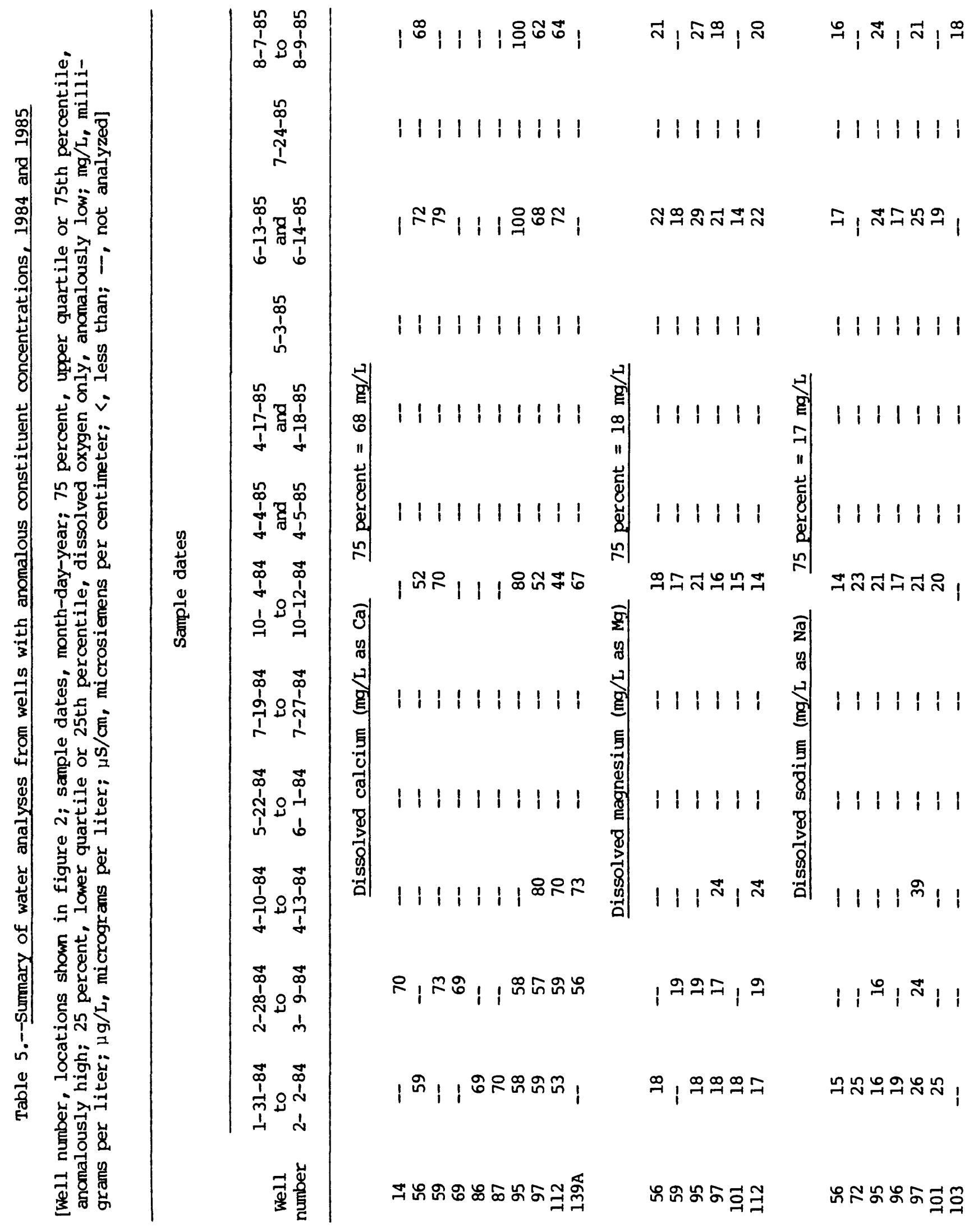




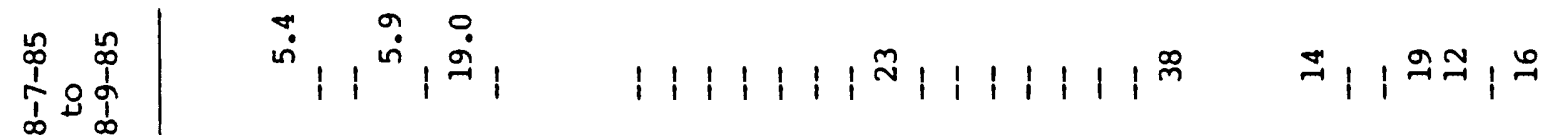

$\underset{\substack{0 \\ i}}{\stackrel{\infty}{i}}$

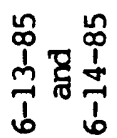
กิ่

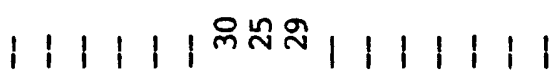

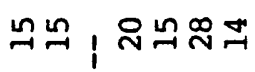
$\underset{\substack{n \\ 0 \\ \vdots \\ \vdots}}{n}$

111111

1111111111111111

1111111

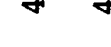

荠

ํํำ

a)

1111111

1111111111111111

1111111

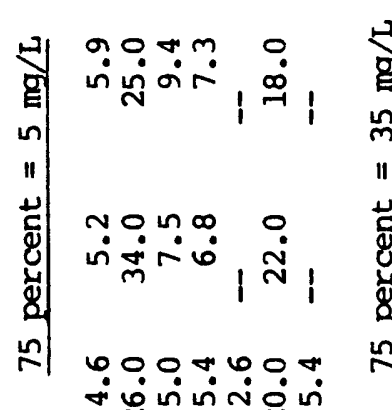

苾

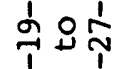

욭

n

$x$

.

สิ่า กิ

म्ञ !̀

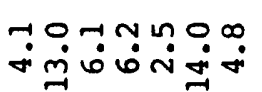

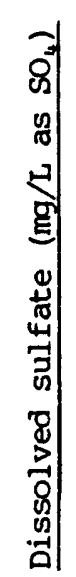

|N||| |

111111111111111

员

111111111 กีลกกำ

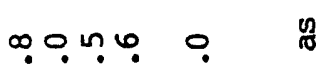

1111111111111111

$$
\text { ก }
$$

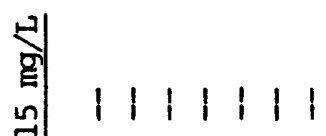

离总

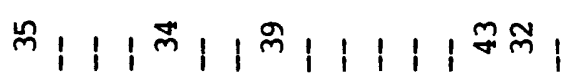

m9, 푼 iे $\dot{m}$

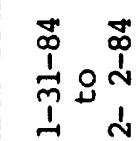

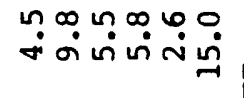

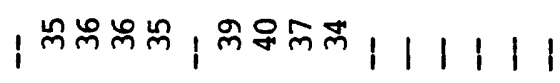

| 1 ลュำษ 


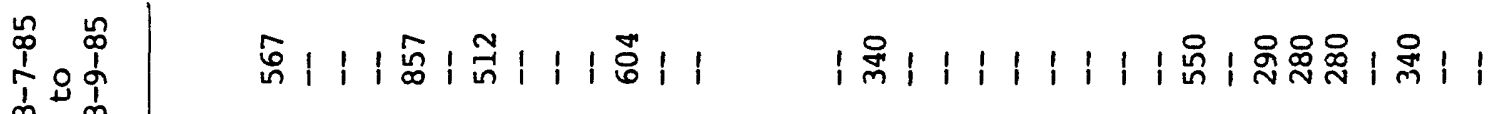

沜

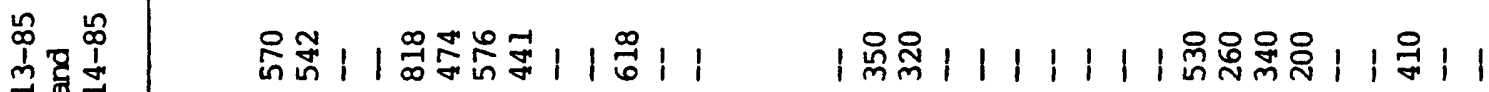

कै

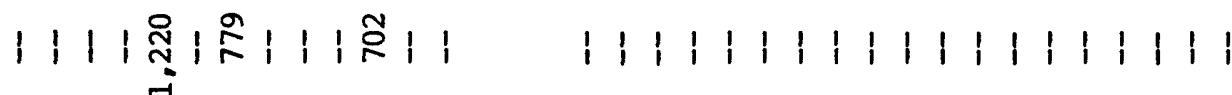

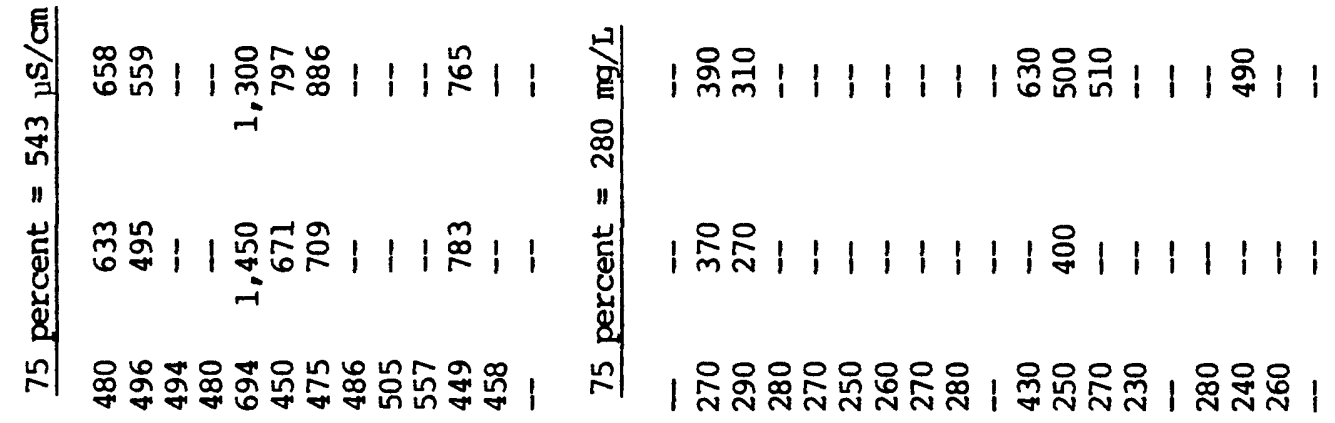

$\frac{1}{1}+\frac{1}{1}$

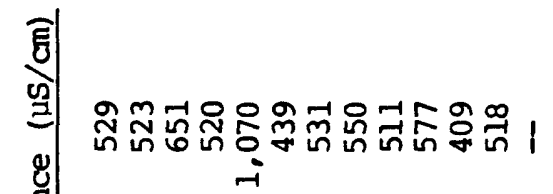

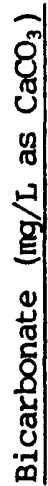

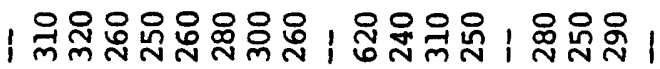

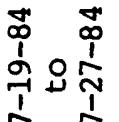

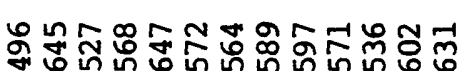

ชกำ

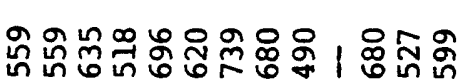

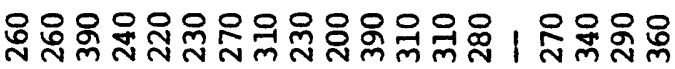

मे

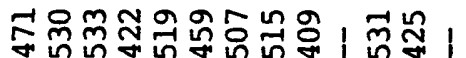

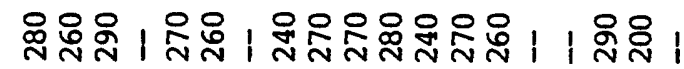

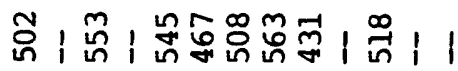

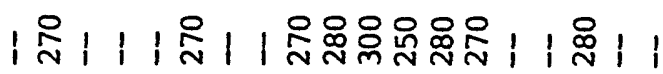




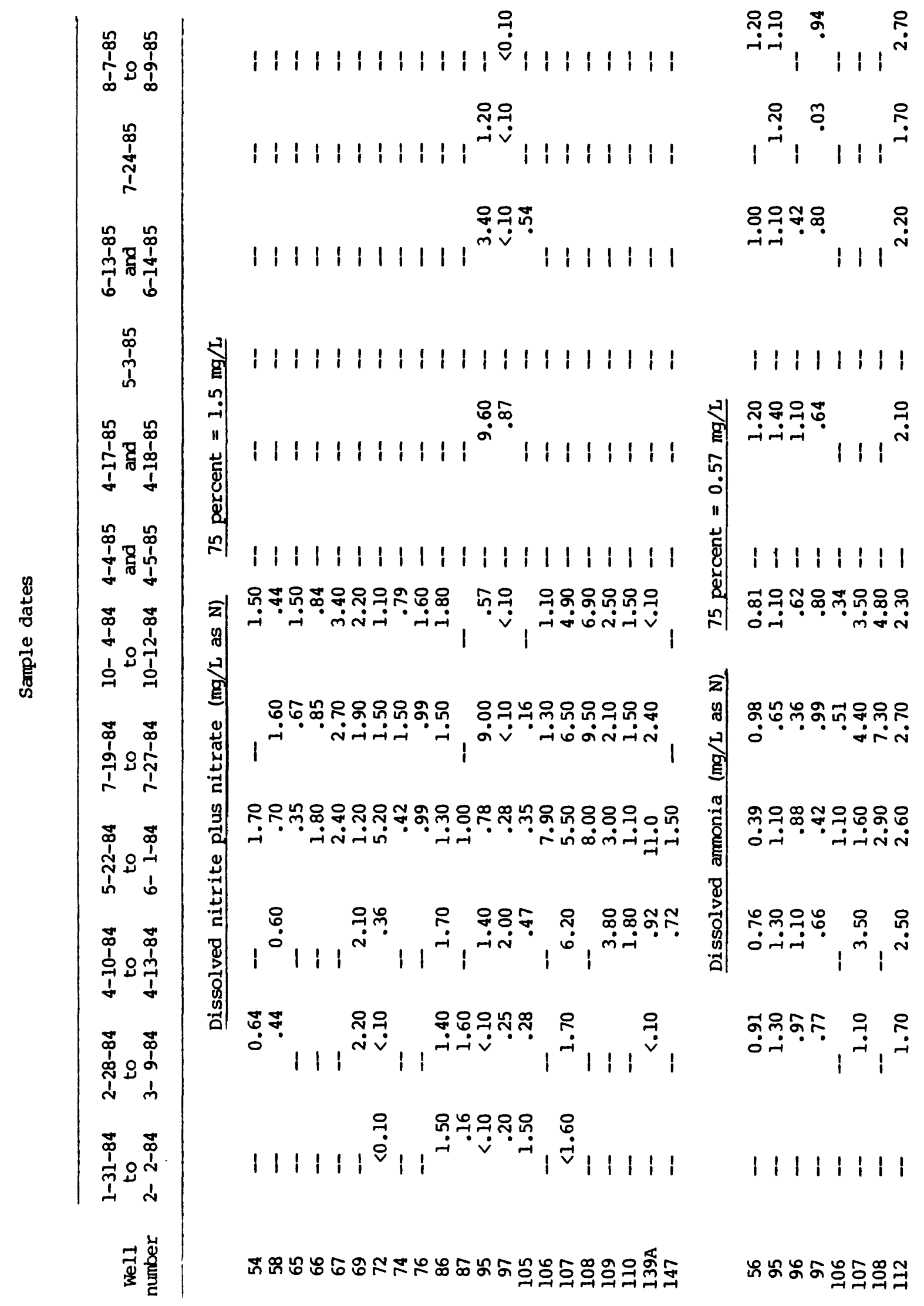




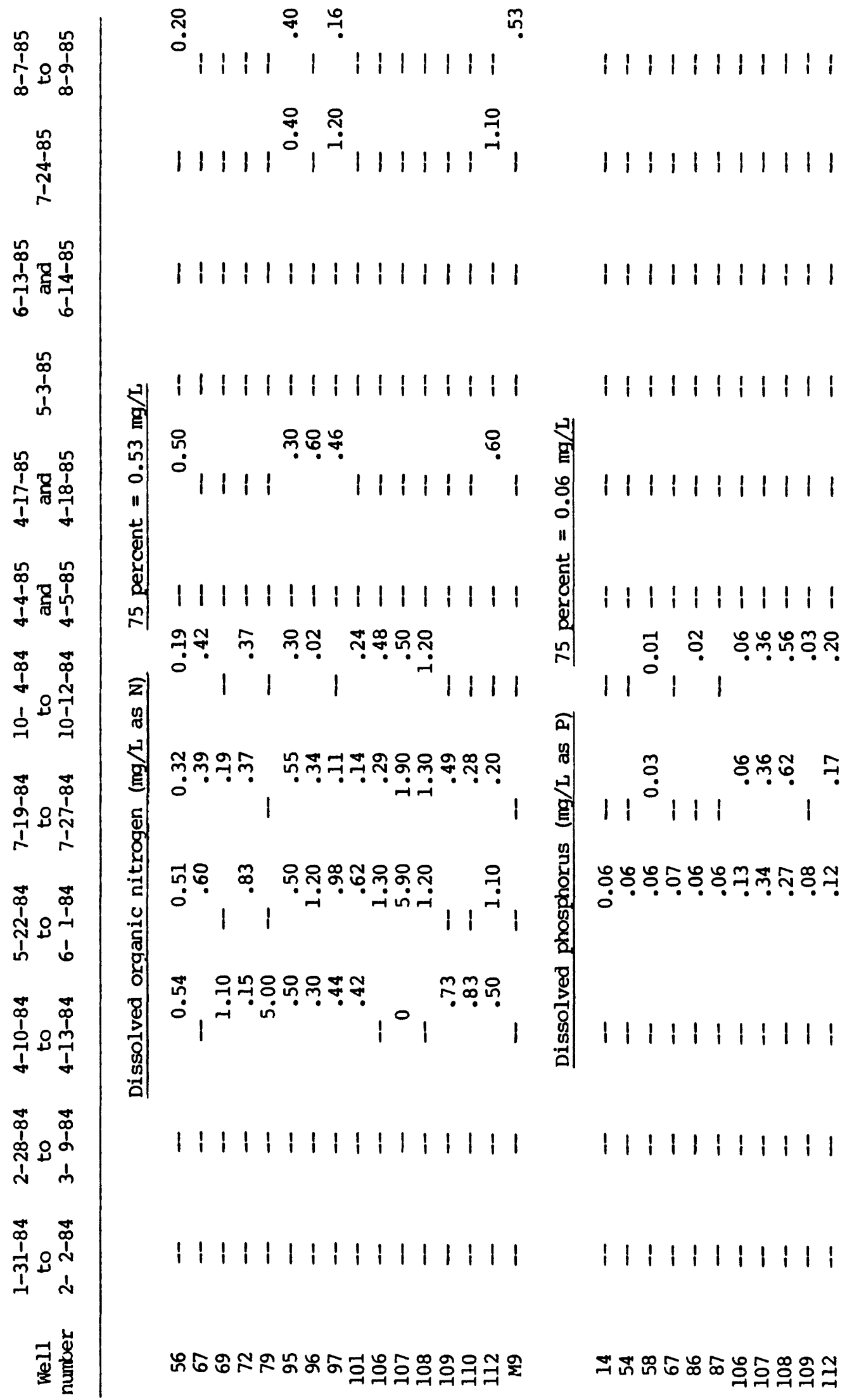




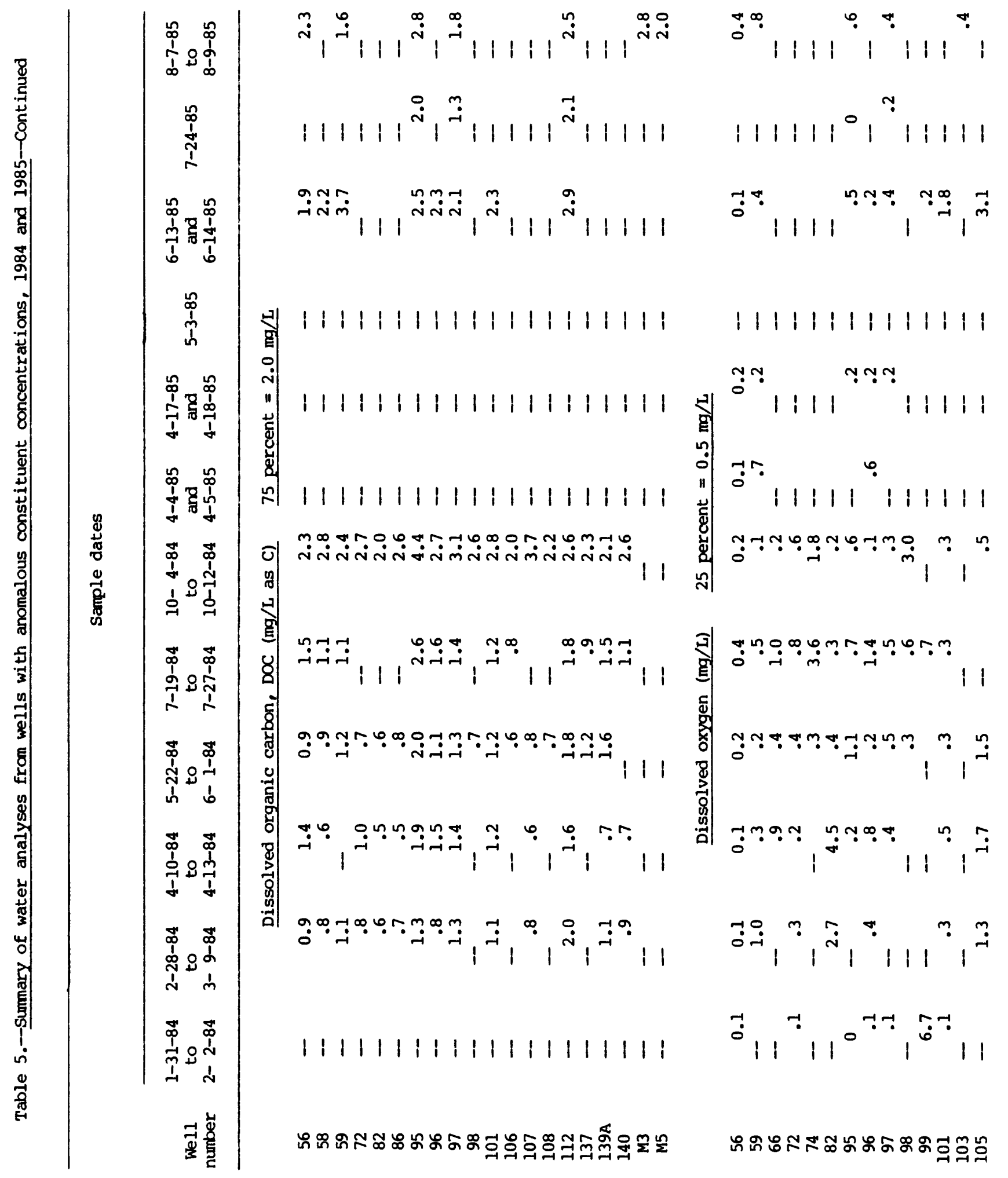


0
1
1
1
$\infty$
0
1
1
1

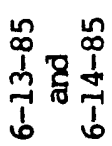

足

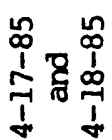

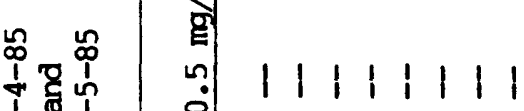

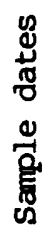

$11^{2} 111^{n}$

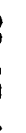

$11^{-1}|1| 11$

$i^{m} 11111$

"ृ

mำ?־

齐

1웡

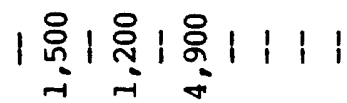

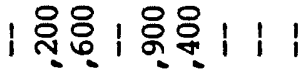

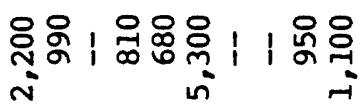

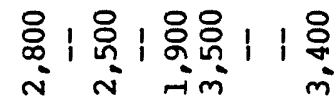

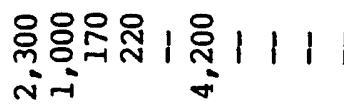

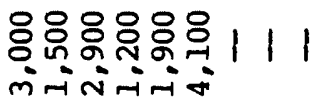

1111111111

111111111

赵

곤돈

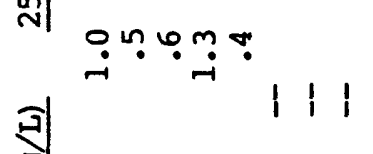

힘

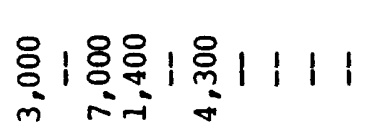

햄

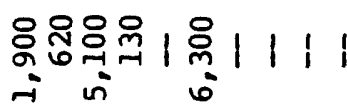

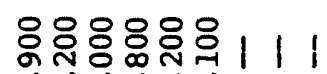
nivinis

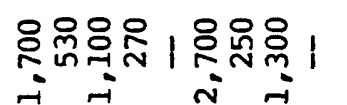

응웅영융유일

0
0
0
0
0
0
0
0
0
0
0
0
0
0
0 तiनiनinim

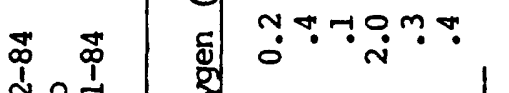

สำ

เก

总总

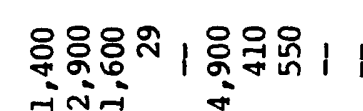

$\stackrel{\Upsilon}{0}^{0}|1| 1$

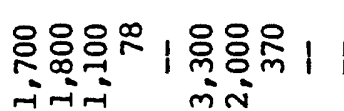

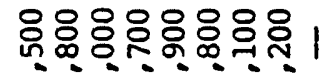

3

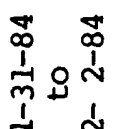

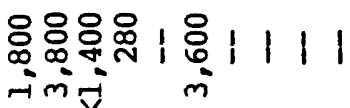

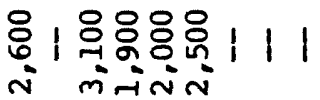

च莪

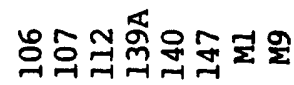

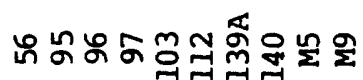

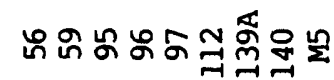




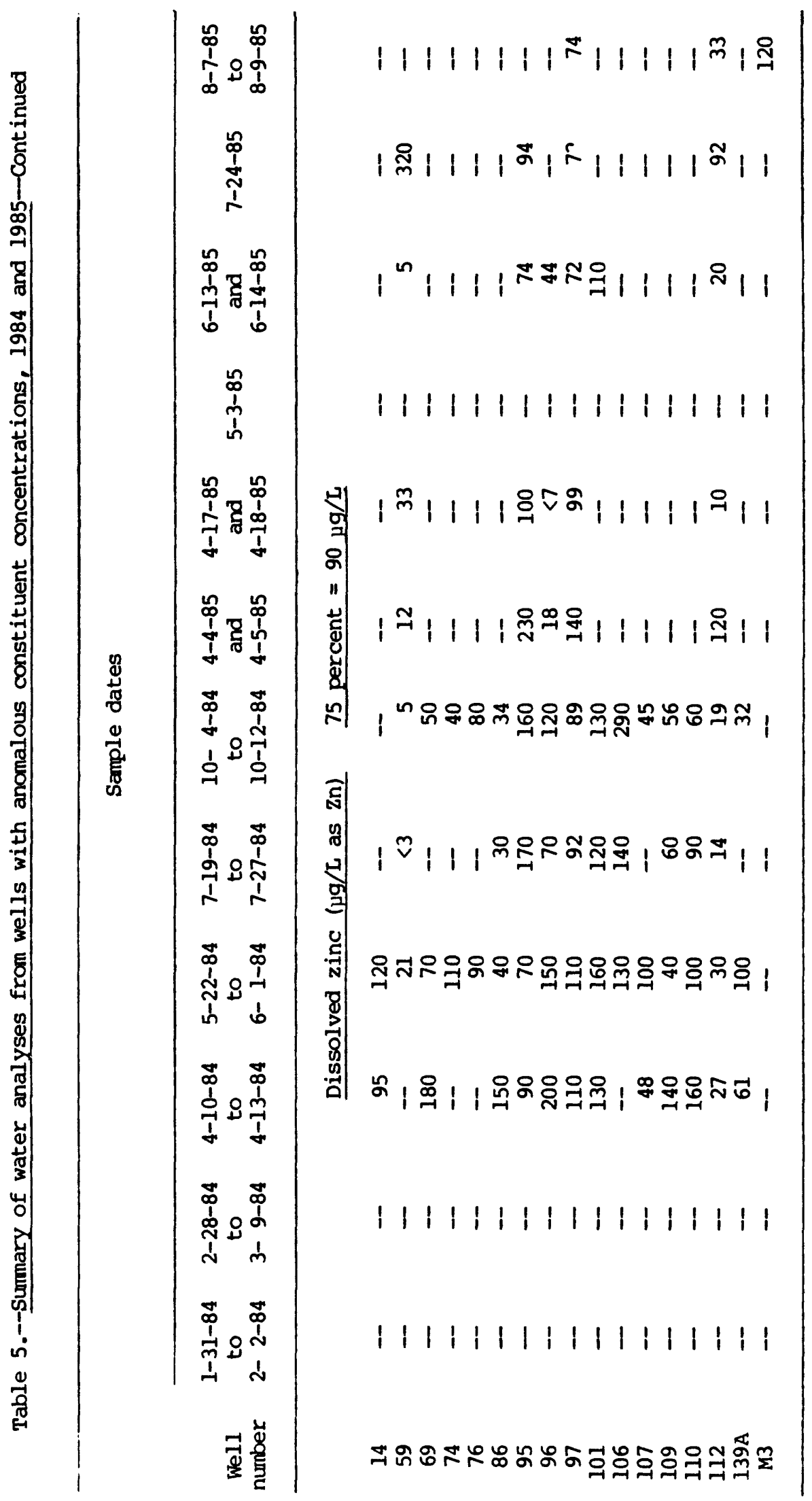



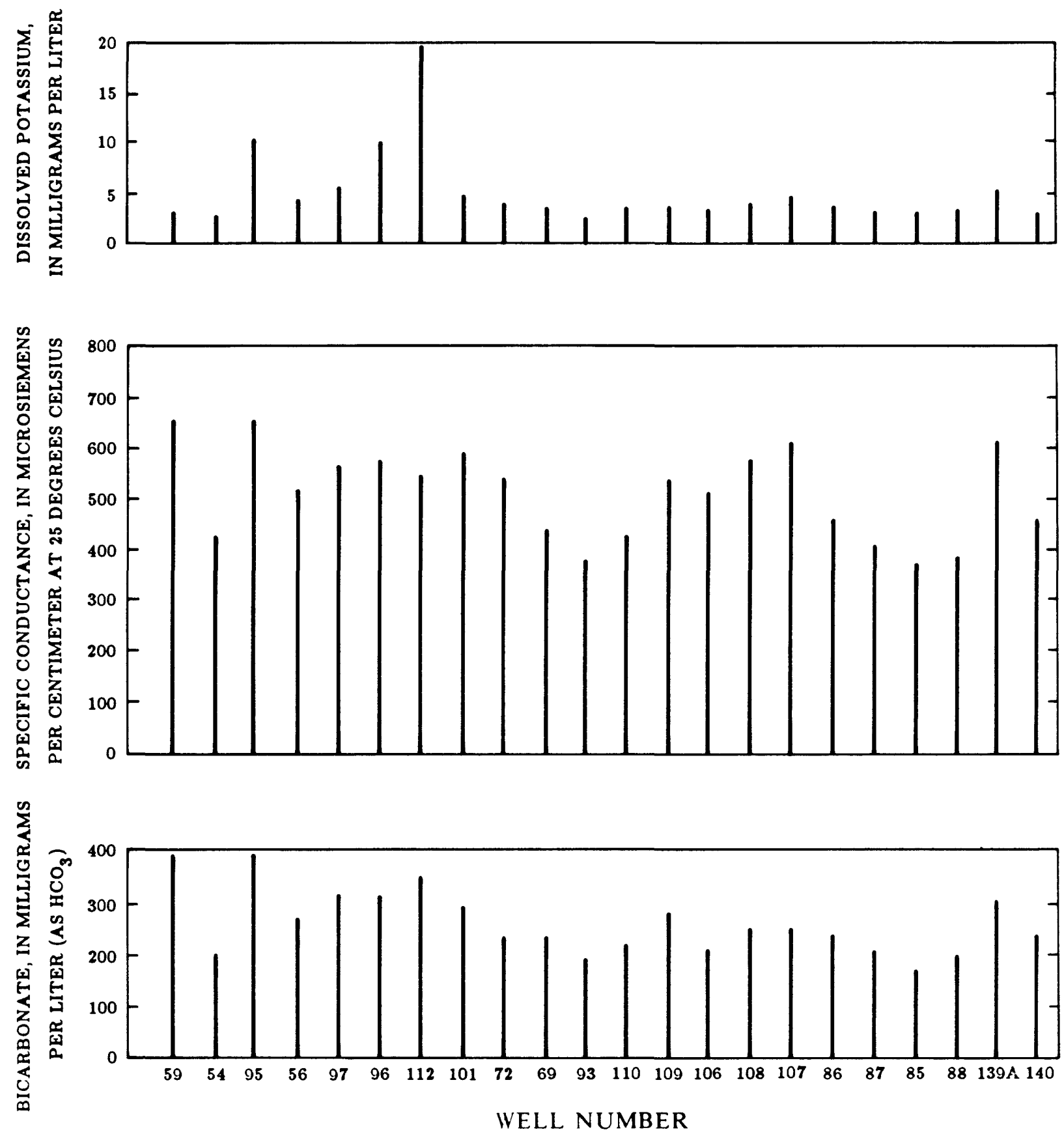

Figure 16A.--Areal distribution of dissolved potassium, specific conductance, and bicarbonate, May 1984. 


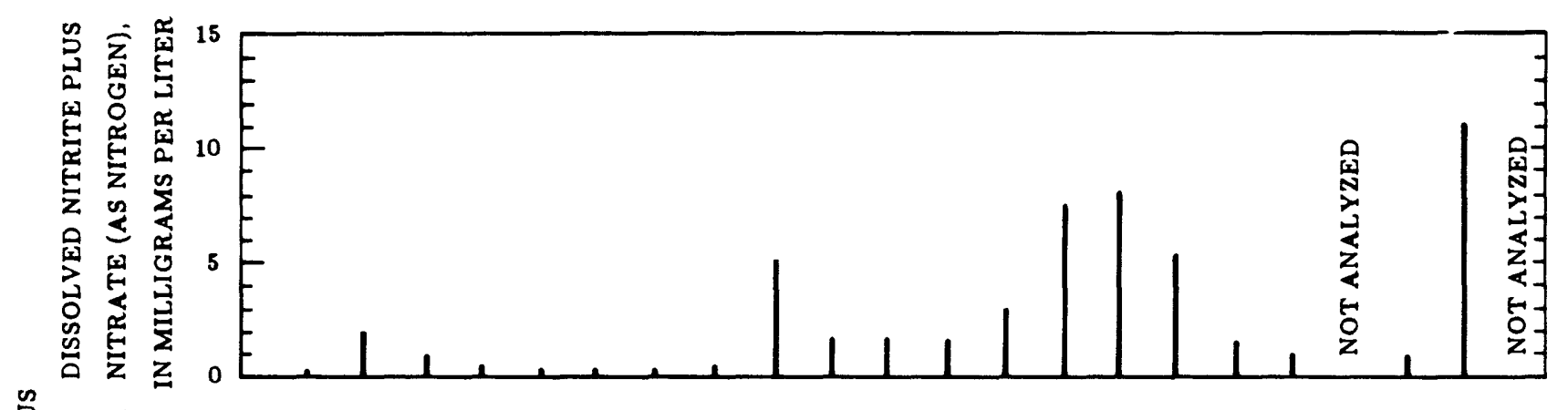

3
3
0
2
3
0
0
2
2
0
0
3
0
0
0
0
0

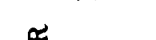
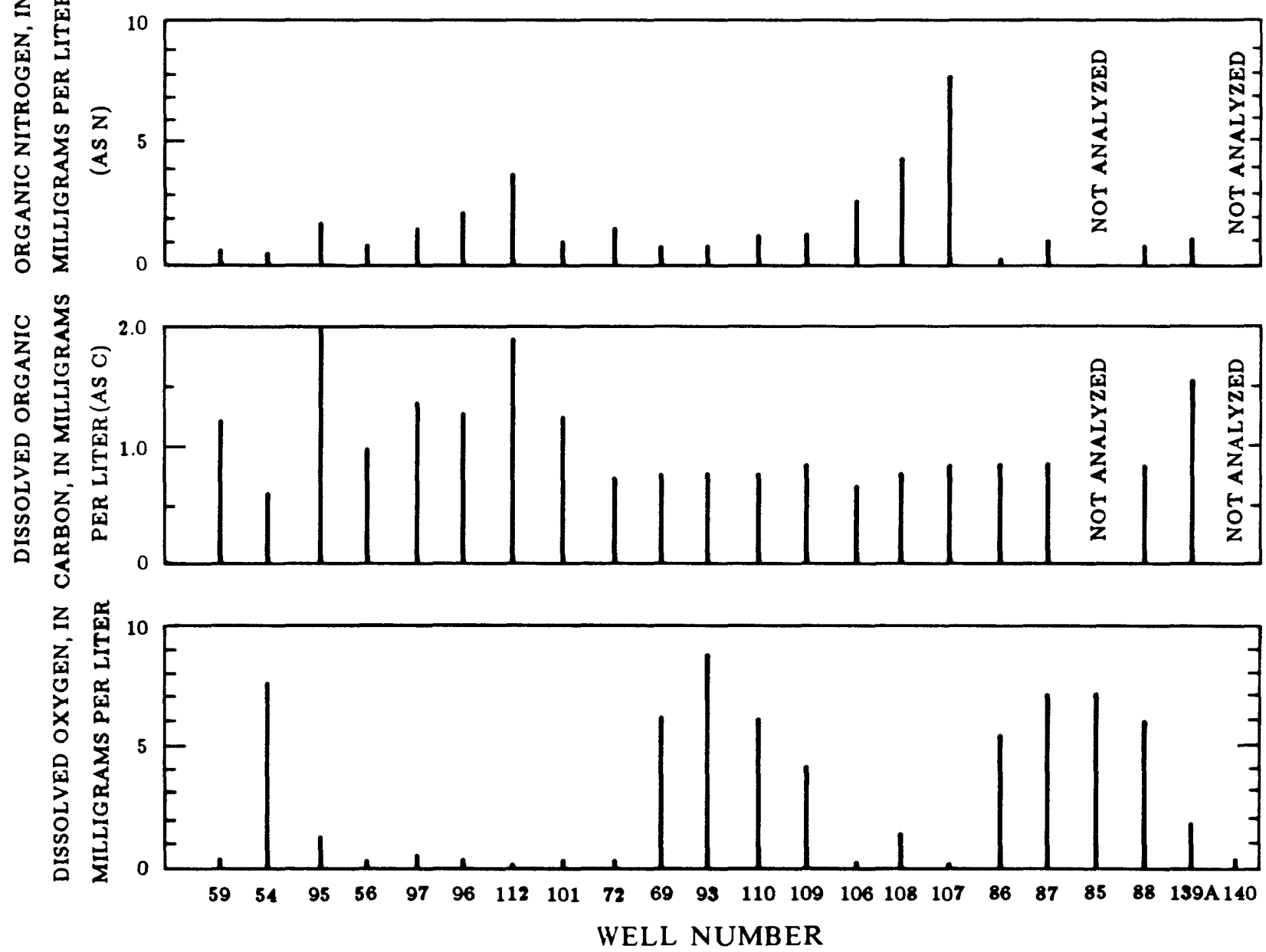

Figurc 16B.--Areal distribution of dissolved nitrite plus nitrate (as nitrogen), ammonia plus organic nitrogen, organic carbon, and oxygen, May 1984. 

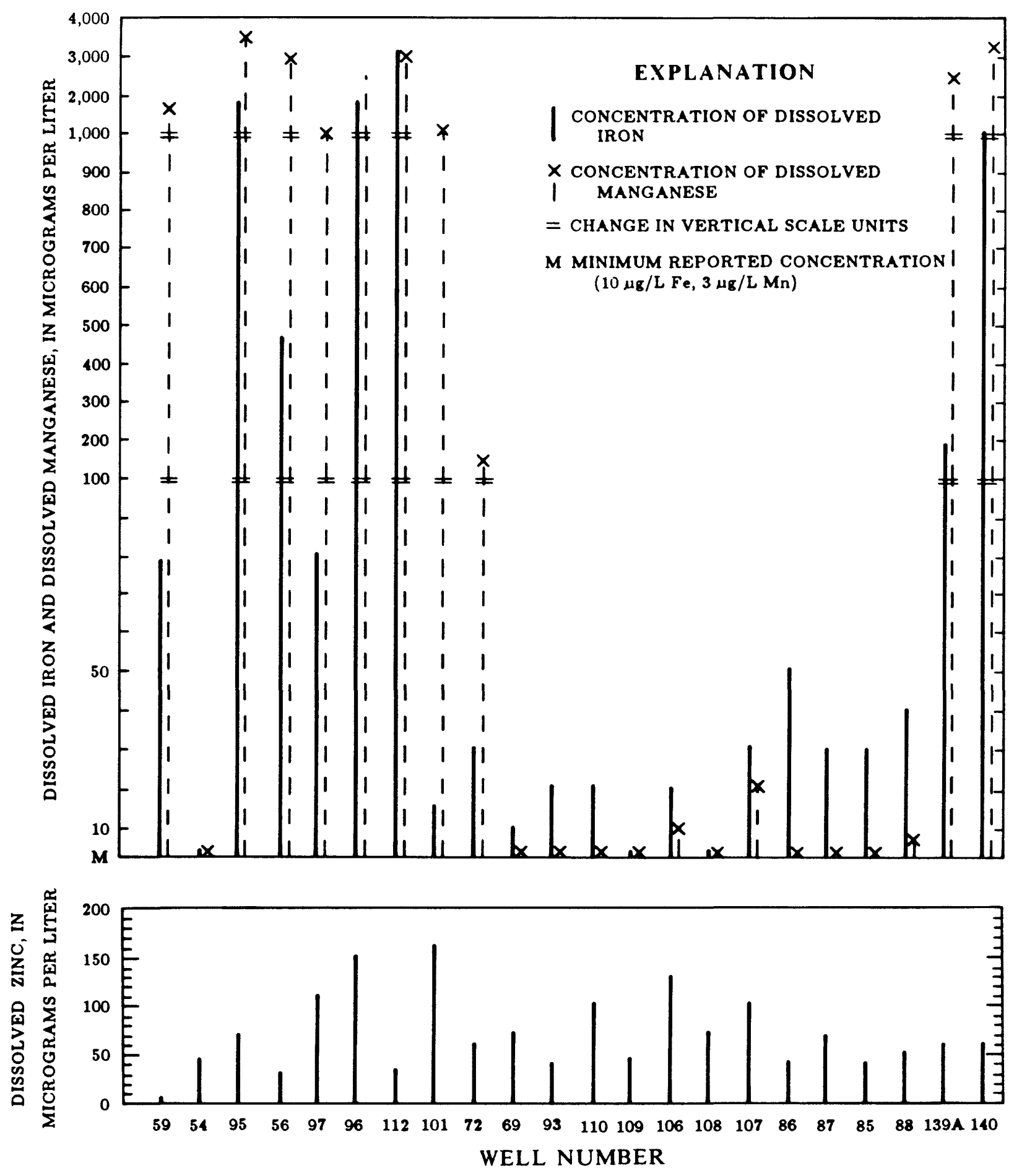

Figure 16C.--Areal distribution of dissolved iron, manganese, and zinc, May 1984. 
Major anion components of ground water include dissolved bicarbonate, sulfate, and chloride. Minor and trace anion components of ground water in the study area are fluoride, nitrate, and phosphorus. Bicarbonate, quantitatively the most significant anion in ground water, is the major component used in calculating alkalinity. Dissolved fluoride concentrations are less than $1 \mathrm{mg} / \mathrm{L}$ in all samples and are not a concern to water users. Dissolved nitrate and phosphorus concentrations are not significant quantitatively but are indicators of ground-water contamination. Dissolved sulfate and chloride concentrations are generally less than $31 \mathrm{mg} / \mathrm{L}$ and are not a problem to water users; anomalously high concentrations contribute to increased mineralization of water.

Generalized trends and diversity of major cations and anions in ground water in the study area (fig. 17) are illustrated by means of a trilinear diagram (Piper, 1944). In trilinear diagrams, cations and anions for each ground-water analysis are plotted as a percentage of the total cations and anions (in milliequivalents per liter) on each side triangle. Cation and anion plots for each sample then are projected into the central diamond area. Generalized composition of the water is determined by locations of projection intersections in the diamond field.

Ground water in the Groveland-Collins area contains predominantly calcium, magnesium, and bicarbonate ions. Highest concentrations ( 75 th percentile or greater) of major and minor cations, particularly potassium, are most consistently in analyses from wells 95,96,97, or 112 (table 5), but annual and seasonal patterns of concentrations vary by constituent. Few annual, seasonal, or areal patterns are indicated for highest concentrations (75th percentile or greater) of sulfate or chloride. Locally, ground water is characterized by high concentrations of bicarbonate or trace elements and nutrients not included in trilinear diagrams.

\section{Dissolved Solids and Specific Conductance}

Comparative degree of water mineralization is described by dissolved-solids concentrations, either by laboratory measurement of residue on evaporation or by calculated sum of major cations and anions plus silica. The most common natural source of dissolved solids in ground water is solution of minerals from soils and rocks. Locally, concentrations of dissolved solids may be caused by variations in rock composition or may indicate possible ground-water contamination. Water tends to become more mineralized with depth and time of residence in unsaturated or saturated rocks, owing to the additive effect of chemical and biochem- 


\section{EXPLANATION}

(DATA POPULATIONS FOR EACH CONSTITUENT ARE SHOWN IN TABLE 4)

MAJOR ANIONS, CLUSTERED

MAJOR CATIONS, CLUSTERED

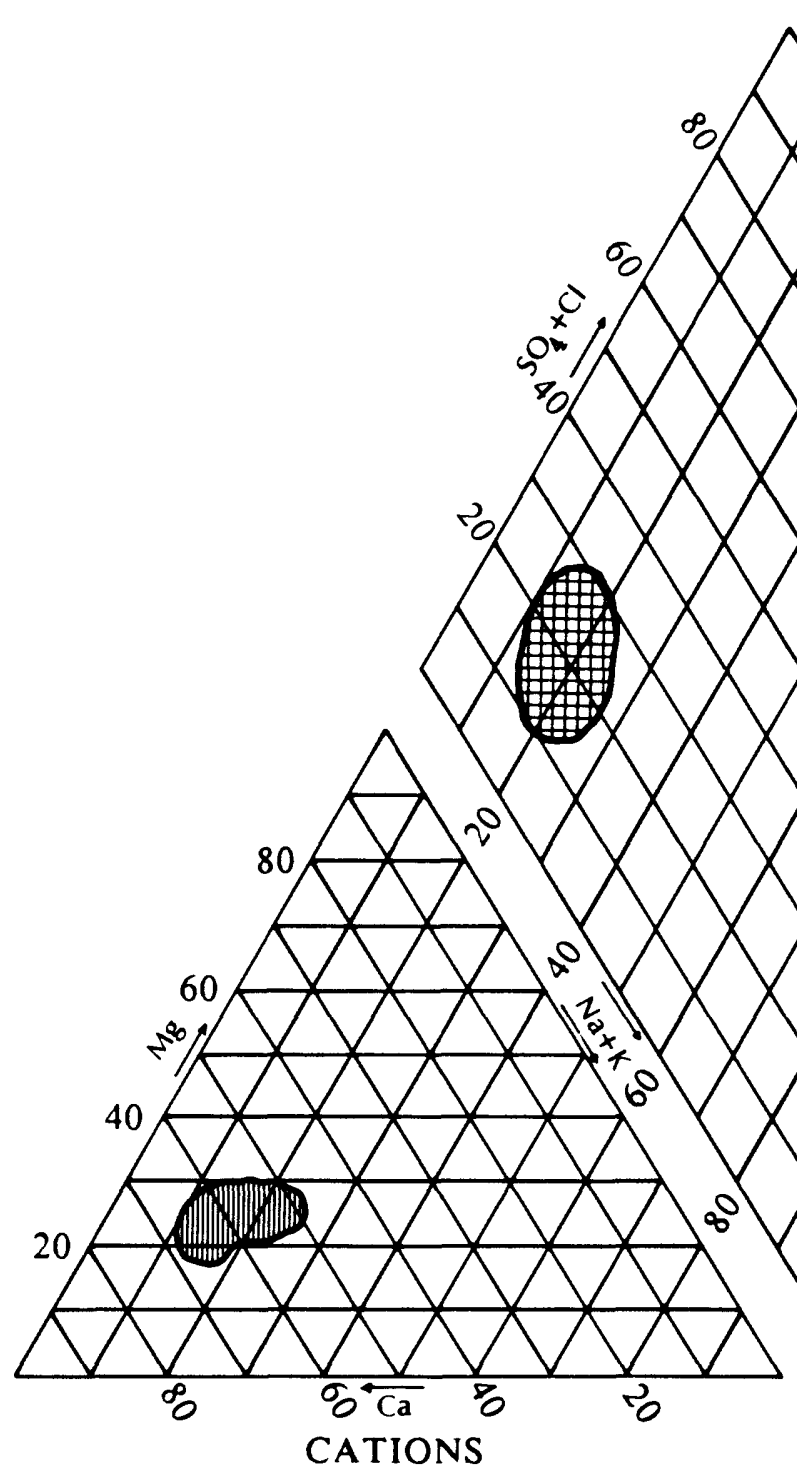

MAJOR ANIONS AND CATIONS, CLUSTERED

PERCENT OF TOTAL, IN MILLIEQUIVALENTS PER LITER

Figure 17.--Chemical character of ground water and major cations and anions, 1984-85. 
ical processes. In the study area, anomalous concentrations of dissolved solids are primarily the result of agricultural, sewage, and wastewater disposal practices.

The recommended maximum 1 imit for dissolved-solids concentrations in public water supplies is $500 \mathrm{mg} / \mathrm{L}$ (EPA, 1982b). High dissolved-solids concentrations often are associated with the presence of cations or anions that may be esthetically or otherwise objectionable to the consumer.

Specific electrical conductance is an indirect measurement of the mineralization of water. Specific conductance is a measurement of the ability of water to conduct an electrical charge--expressed as siemens, the reciprocal of resistance in ohms--across a centimeter of water at $25{ }^{\circ} \mathrm{C}$. Because specific conductance is measured easily with a relatively high degree of accuracy, it is an efficient and inexpensive method of quickly determining the degree of mineralization of a water sample.

A relatively constant relation has been documented between dissolved-solids concentrations and specificconductance values. The concentration of dissolved solids generally should be from 0.55 to 0.75 times the value of specific conductance (Hem, 1985, p. 165). Dissolved-solids/ specific-conductance ratios are not only a means for checking reliability of laboratory data, particularly cation and anion concentrations, but also provide a way to relate specific-conductance values to water-use standards. If the national drinking water limit for dissolved solids is $500 \mathrm{mg} / \mathrm{L}$, then the national drinking water limit in terms of specific conductance would be about [ $(500 \mathrm{mg} / \mathrm{L}$ ) $x$ (dissolved solids/specific-conductance ratio)]. If an average ratio of 0.59 is used for the study area, $850 \mu \mathrm{s} / \mathrm{cm}$ (at $25{ }^{\circ} \mathrm{C}$ ) specific conductance would be equivalent to $500 \mathrm{mg} / \mathrm{L}$ dissolved solids.

The median value for all 1984-85 onsite specificconductance data in the study area was $485 \mu \mathrm{s} / \mathrm{cm}$; individual values ranged from 267 to $1,450 \mu \mathrm{s} / \mathrm{cm}$. Conductance values are consistently and anomalously high in samples from wells $56,59,72,95,96,97,101,108,112$, and 147, and exceed $850 \mu \mathrm{S} / \mathrm{cm}$ in samples from wells 95 and 97 (table 5).

When conductance values for water from several of these wells are plotted on a time scale (fig. 18), seasonal trends are evident. Values are highest immediately after spring ground thaw each year. Conductance values are greatest and remain consistently highest in analyses from well 95, and highest annual values are in analyses from wells 95, 96, 97, and 112. Conductance is relatively constant throughout the year in water samples from well 105. 


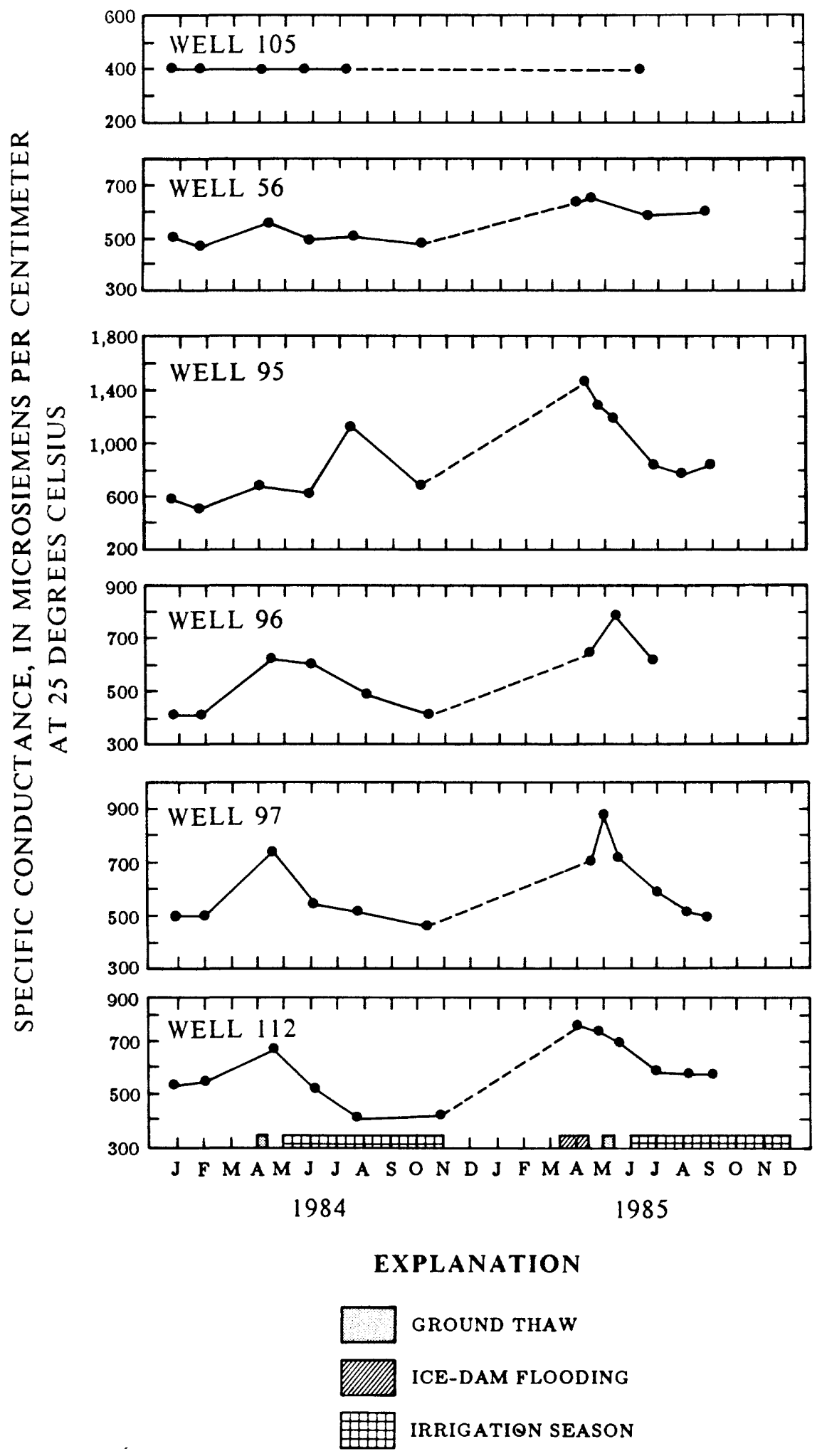

Figurc 18.--Temporal variations in, specific conductance, 1984-85.

(Dashed lines indicate periods when no data were available) 
This well is open only to deep (greater than $290 \mathrm{ft}$ ) wateryielding zones. Little information is available on movement of water between water-yielding zones in basalt, but data from well 105 indicate that shallow contaminated zones do not affect quality of water at depth or that contaminant concentrations are diluted at depth.

High conductivity values from well 95 may be better understood by comparing water-level and saturated-sediment information presented in figures $15 \mathrm{~A}$ and $15 \mathrm{~B}$, section $\mathrm{B}^{\prime}-\mathrm{B}^{\prime}$ ' (fig. 7D), and altitudes of the basalt surface (fig. 6). Water moving northwestward in perched and saturated zones near well 95 may pool temporarily behind the prominent basalt mound immediately west of the well. This pooling of water creates both unusually high water levels and extended periods when sediments above the basalt are saturated. Contaminants resulting from the perennial application of potato-processing wastewater near well 95 infiltrate to unsaturated sediment and may be flushed to the ground-water system more quickly in this area than in other areas because water levels are relatively near land surface for extended periods of time.

\section{pH, Alkalinity, and Hardness}

Hydrogen ion activity is reported in pH units. In general, $\mathrm{pH}$ describes whether water is neutral ( $\mathrm{pH}$ equals 7), acidic ( $\mathrm{pH}$ less than 7), or basic ( $\mathrm{pH}$ greater than 7). The $\mathrm{pH}$ is controlled primarily by chemical reactions and equilibria among ions in solution, particularly the carbonate system, and is an indicator of the chemical behavior certain solutions may have toward minerals (Hem, 1985, p. 61-62). The $\mathrm{pH}$ of most natural water is within the range of 5.0 to 9.0 (National Academy of sciences, National Academy of Engineering, 1973, p. 80), but the range of $\mathrm{pH}$ recommended for public water supplies is 6.5 to 8.5 (EPA, 1982b).

Median value for all 1984-85 pH data was 7.4; individual values ranged from 6.8 to 8.0 . Areal and temporal values of $\mathrm{pH}$ were relatively constant in the study area.

Alkalinity indicates the capacity of water to neutralize acid and is therefore a measure of the chemical ability to buffer water against changes in pH. Chemical components of natural water that increase alkalinity include carbonate $\left(\mathrm{CO}_{3}\right)$, bicarbonate $\left(\mathrm{HCO}_{3}\right)$, carbon dioxide $\left(\mathrm{CO}_{2}\right)$, and phosphate, borate, or silicate compounds.

Alkalinity resulting from natural compounds is not considered a health hazard but generally is associated with high $\mathrm{pH}$ values and excessive dissolved solids. Water containing concentrations of about $400 \mathrm{mg} / \mathrm{L}$ alkalinity or 
greater may have an unpleasant, bitter taste (National Academy of Sciences, National Academy of Engineering, 1973, p. 54). Also, high alkalinity in irrigation water may indirectly increase the relative proportion of sodium in soil water through ion exchange of calcium and magnesium with sodium. During the ion-exchange process, calcium and magnesium ions decrease and sodium ions increase. The increase in sodium may result in soil and plant damage (EPA, 1976 , p. 8).

Alkalinity in ground water of the study area is produced chiefly by dissolved bicarbonate. Bicarbonate may be added to ground water from many natural sources, including absorption and fixation of carbon dioxide from the air, decomposition of organic matter, or other domestic sources such as animal, human, manufacturing, or agricultural wastes. Concentrations of bicarbonate exceeding $700 \mathrm{mg} / \mathrm{L}$ may be unhealthful to most people (Mckee and Wolf, 1963, p. $146)$ but, in general, bicarbonate concentrations in ground water are not of concern in drinking water. The median

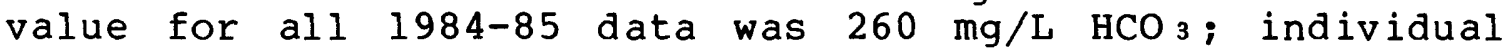
values ranged from 140 to $630 \mathrm{mg} / \mathrm{L} \mathrm{HCO}_{3}$. Anomalous concentrations of bicarbonate are compiled in table 5 .

Areal and temporal trends in bicarbonate concentrations are evident (table 5 and fig. I6A). Concentrations are consistently highest in wells 56, 59,95,96, 97, and 112, which are located in or are hydraulically downgradient from the potato wastewater field. Concentrations are highest during spring and summer.

Hardness is caused principally by dissolved calcium and magnesium in water. Hardness usually is expressed in milligrams per liter as $\mathrm{CaCO}_{3}$, but also may be defined in terms of grains of hardness: 1 grain per U.S. gallon = $17.12 \mathrm{mg} / \mathrm{L} \mathrm{CaCO}_{3}$ hardness (Johnson Division, Inc., 1966, p. 66). The consumer often judges hardness by the amount of soap required to produce a lather and by scale buildup in water supply pipes, plumbing fixtures, and cookware. Nationally, EPA (1976, p. 75) has established the following hardness categories: $0-75 \mathrm{mg} / \mathrm{L}$ is soft, $76-150 \mathrm{mg} / \mathrm{L}$ is moderately hard, $151-300 \mathrm{mg} / \mathrm{L}$ is hard, and more than 300 $\mathrm{mg} / \mathrm{L}$ is very hard.

Hardness in domestic supplies probably is not objectionable at concentrations less than $100 \mathrm{mg} / \mathrm{L}$ (Mckee and Wolf, 1963, p. 195). Chemically softened water may be preferable for esthetic reasons or for industrial uses but may be expensive. Also, use of sodium compounds in some water-softening processes may increase the sodium content of drinking water, a concern to people on sodium-restricted diets (EPA, 1977, p. 120-125). 
The median hardness value for all 1984-85 data was $210 \mathrm{mg} / \mathrm{L} \mathrm{CaCO}$. Individual values ranged from 140 to $370 \mathrm{mg} / \mathrm{L} \mathrm{CaCO}_{3} \cdot$ More than 90 percent of all ground-water analyses contained more than $151 \mathrm{mg} / \mathrm{L} \mathrm{CaCO}_{3}$.

\section{Nutrients and Organic Carbon}

Nutrients are compounds of nitrogen and phosphorus and are essential to plant and animal life. Nutrients in ground water are generally low, $0.50 \mathrm{mg} / \mathrm{L}$ dissolved nitrogen and $0.02 \mathrm{mg} / \mathrm{L}$ dissolved phosphorus, in areas of few 1 and- and water-use activities. In most instances, increased land and water use, particularly for agriculture and nonsewered urban development, is followed by increased concentrations of nutrients, specifically nitrate ( $\left.\mathrm{NO}_{3}^{-}\right)$, ammonium $\left(\mathrm{NH}_{4}^{+}\right)$, organic nitrogen (nitrogen that is incorporated into organic substances), and phosphorus in ground water. Selected sources of nitrogen compounds and the complexity of the nitrogen cycle in particular are shown in figure 19 and are discussed in reports by Freeze and Cherry (1979, p. 413-416) and Stumm and Morgan (1981).

Nitrate concentrations are particularly useful indicators of ground-water contamination because nitrate is the stable end-product of many biochemical processes and, in aerobic (oxygenated) ground-water systems, may accumulate with time and migrate large distances from contamination sources. In anaerobic (nonoxygenated) environments, nitrate concentrations decrease with distance from the source because nitrate is metabolized by anaerobic bacteria.

Nitrate in ground water may be dissolved from natural sources such as atmospheric nitrogen, decaying plants, and soluble compounds or minerals in soils and rocks. More commonly, nitrate is derived from the biochemical conversion of organic nitrogen and ammonium or originates from livestock or human waste and fertilizers. Factors that affect nitrate concentrations in ground water include landcultivation practices, climate, soil and rock composition and properties, well depth, well penetration below the water table, presence of phreatophytes, and anaerobic conditions (Spruill, 1983, p. 977). In the study area, potential man-caused sources of nitrate in water supplies are cropland and lawn fertilizers, septic-tank drain fields, sewage lagoons, food-processing wastes, barnyards, feedlots, and landfills. The maximum limit for public water supplies (EPA, 1982a) is $45 \mathrm{mg} / \mathrm{L}$ nitrate (expressed as nitrate) or 10 $\mathrm{mg} / \mathrm{L}$ nitrate (expressed as nitrogen). Concentrations as high as $11 \mathrm{mg} / \mathrm{L}$ nitrite plus nitrate (as nitrogen, hereafter referred to as nitrate-nitrogen) in the study area probably are due to contamination from land-use activities. 


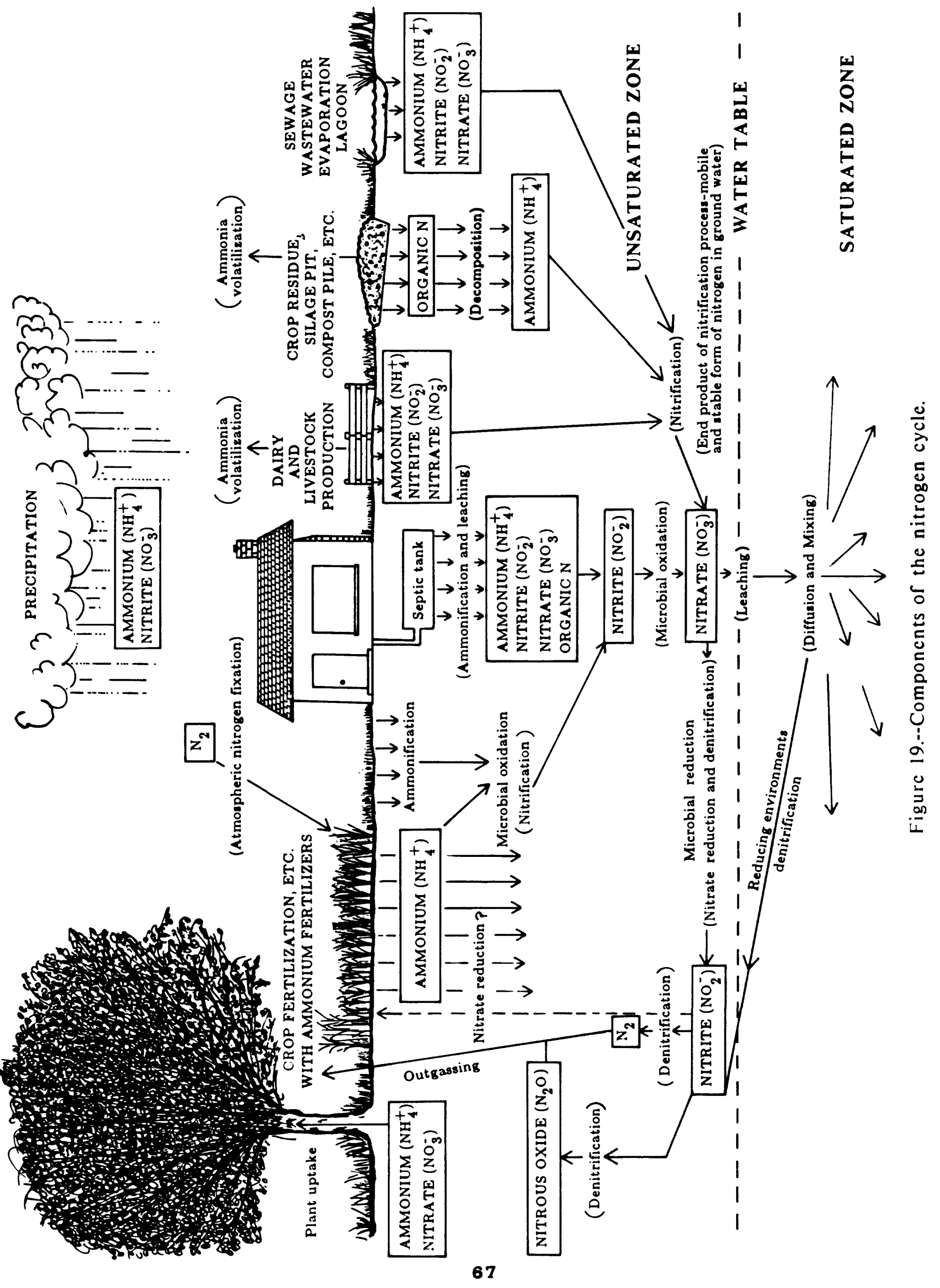


The median for all 1984-85 nitrate-nitrogen data was $0.55 \mathrm{mg} / \mathrm{L}$; individual values ranged from less than 0.10 to $11 \mathrm{mg} / \mathrm{L}$. Anomalous 1984-85 nitrate-nitrogen concentrations are compiled in table 5, and areal trends are shown in figure 16B. Concentrations are consistently high but are lower than maximum drinking water limits in wells 67,69 , $86,107,108,109$, and 110. Each of these wells is in Collins or is hydraulically downgradient from collins, an area with many large-capacity sewage and wastewater disposal systems. Also, the area near well 109 is a bulk storage and transfer point for liquid ammonia fertilizers. Fertilizer spillage and runoff from truck and equipment cleaning drain to a collection pit in the work yard, and nitrate-nitrogen probably infiltrates to the ground-water system. Nitratenitrogen in water samples from well 86 may be either from land-use activities hydraulically upgradient from the well or from infiltration of livestock wastes near the well. (Well 86 is located in the basement of a building that has attached stock holding pens.) Periodic or seasonal (spring to fall) increases in nitrate-nitrogen concentrations in several wells, including $54,72,87,95$, and $139 \mathrm{~A}$, probably are caused by flushing of contaminants from land surface, soil, or unsaturated rock during ground thaw; by rising ground-water levels; or by application of irrigation water.

Ammonium, organic nitrogen, and phosphorus are also indicators of localized sources of ground-water contamination. Areally, these nutrients are quantitatively less important than nitrate-nitrogen because they are converted rapidly to other ion species by biochemical processes, are adsorbed on soil and rocks, or are used by plants. Potential sources of ammonium, organic nitrogen, and phosphorus in ground water are infiltration of sewage lagoon wastes, septic-tank drain-field leachates, or food-processing wastes; crop residues and compost; and cropland or lawn fertilizers. Anomalous concentrations (1984-85 data) of these compounds are compiled in table 5 and areal trends of ammonium plus organic nitrogen concentrations are shown in figure 16B. Patterns of nutrients probably are related to infiltration of fertilizer wastes in the Collins area and effluent in the potato wastewater field.

Dissolved organic carbon (DOC) is the organic carbon that will pass through a 0.45-micrometer filter. Sources of DOC are precipitation and organic material, such as crop residue, manure, mulch, solid or liquid food-processing wastes, and fossilized organic matter present in soil and rock. The range of DOC in precipitation is about 1 to 10 $\mathrm{mg} / \mathrm{L}$ (as carbon) and, in interstitial water in unsaturated rock, about 2 to $30 \mathrm{mg} / \mathrm{L}$ (Thurman, 1985, p. 15, 23). The range of DOC in ground water commonly is from less than 0.1 to $15 \mathrm{mg} / \mathrm{L}$; the median concentration is $0.7 \mathrm{mg} / \mathrm{L}$ (Leenheer 
and others, 1974, p. 361). DOC concentrations are generally higher in soil and unsaturated rock than in ground water. Under aerobic conditions, organic compounds are dissolved from the land surface and infiltrate through unsaturated rock.

DOC is biologically or chemically removed from the water as it oxidizes to carbon dioxide and DOC/metal complexes are adsorbed to clays. Under anaerobic conditions, DOC concentrations may increase as nitrate, sulfate, and carbon dioxide compounds are oxidized before organic carbon compounds (Thurman, 1985, p. 18).

Quantitatively and with respect to water use in the study area, DOC is of little concern, but it is an indicator of conditions that may produce water-quality problems. Where soil and unsaturated rock are rich in organic matter, carbon dioxide produced by microbial decay of organic carbon may contribute to increased alkalinity of water in both unsaturated and saturated rock. Metal ions, particularly iron, are concentrated in unsaturated rock by the process of DOC/metal complex formation and adsorption onto clay. Sorbed organic carbon then is oxidized microbially and removed as carbon dioxide. Anomalously high concentrations of DOC in ground water may indicate localized areas of anaerobic conditions in unsaturated and saturated rock, which may produce significant changes in the quality of water. The median for all 1984-85 DOC data was $1.1 \mathrm{mg} / \mathrm{L}$ carbon; individual values ranged from 0.3 to $4.4 \mathrm{mg} / \mathrm{L}$. Anomalous concentrations of DOC from 1984-85 analyses are presented in table 5 and areal trends are shown in figure 16B.

Concentrations of DOC are consistently high (table 5 and figure 16B) near the potato wastewater field (wells 95, 96, 97, and 112). Patterns of concentrations indicate an areawide flushing of organic materials to the ground-water system in the fall, perhaps the result of tilling of crop residues and late season irrigation.

\section{Dissolved Oxygen, Iron, Manganese, and $\mathrm{Zinc}$}

In ground-water quality investigations, dissolvedoxygen concentrations are indicators of chemical and biochemical environments in both unsaturated and saturated rock. Oxygen dissolved in ground water usually is derived from recharge sources. Solubility of oxygen in water depends on the partial pressure of oxygen in the atmosphere, the degree of mineralization of the water, and the temperature. Dissolved oxygen can exist at great depths in wateryielding zones that have little or no oxidizable material in 
the water flowpath and also can be present in any zones where the water's residence time is short compared to the rate of oxygen consumption.

The abundance or scarcity of dissolved oxygen in water as it moves through subsurface soil and rock is a major factor determining the sequences of chemical and biochemical reactions that define the unique chemical character of subsurface water. Other factors that may affect oxygen consumption and chemical evolution of solutions include soil structure; rock texture, porosity, hydraulic conductivity, and mineral composition; nature and frequency of infiltration; availability, nature, and depth of inorganic and organic constituents; depth to water table; and temperature (Freeze and Cherry, 1979, p. 245). Because few of these factors remain constant in subsurface soil and rock with depth or time, concentrations of dissolved oxygen in unsaturated and saturated rock may be highly variable.

In the study area, baseline concentrations of dissolved oxygen from the ground-water system are generally greater than $4 \mathrm{mg} / \mathrm{L}$. Comparatively low concentrations of dissolved oxygen are indicators of increased oxygen consumption in the unsaturated zone. The increased oxygen consumption generally is caused by land-use activities: (1) Increased organic and nutrient concentrations in soil and unsaturated rock (irrigation and land fertilization, field tillage, and land spreading of food-processing and sewage wastes); (2) increased biochemical activity; (3) decreased oxygen and nitrogen compounds; (4) formation of anaerobic conditions in soil and unsaturated rock; and (5) increased concentrations of some water-quality constituents in anaerobic environments. The median value for all 1984-85 dissolved-oxygen concentrations was $1.0 \mathrm{mg} / \mathrm{L}$; individual values ranged from 0.0 to $8.9 \mathrm{mg} / \mathrm{L}$. Anomalous concentrations ( 0 to $25 \mathrm{th}$ percentile of the total data population) are shown in table 5 and areal trends are shown in figure 16B.

Patterns of highest and lowest dissolved-oxygen concentrations are most significant as indicators of aerobic or anaerobic subsurface environments. Biochemical processes related to aerobic and anaerobic environments are particularly important to the solution or precipitation of iron and manganese compounds--localized contaminants in the study area.

Iron is a common constituent in soil and rock as $\mathrm{Fe}^{+3}$ (ferric iron), a relatively insoluble ion. In anaerobic environments, $\mathrm{Fe}^{+3}$ is reduced to highly soluble ferrous iron $\left(\mathrm{Fe}^{+2}\right)$ through microbial and chemical processes, particularly in association with organic, nitrogen, and sulfur compounds. Manganese is also a common component of soil and rock and 
exists as $\mathrm{Mn}^{+4}$, which is less soluble than $\mathrm{Fe}^{+3}$. Under anaerobic conditions, $\mathrm{Mn}^{+4}$ is reduced to $\mathrm{Mn}^{+2}$, a highly soluble ion.

In general, when dissolved-oxygen concentrations are relatively high, dissolved iron and manganese concentrations are relatively low. Addition of organic or nitrogen compounds to soil and unsaturated rock increases oxygen consumption (oxygen concentrations decrease), creates anaerobic environments, and results in higher dissolved iron and manganese concentrations. When subsurface environmental conditions change and water becomes more oxygenated, subsequent oxidation of the dissolved $\mathrm{Fe}^{+2}$ and $\mathrm{Mn}^{+2}$ ions results in precipitation of iron and manganese oxides.

Discussion of the complex mechanisms of these and many other related biochemical reactions in aerobic and anaerobic subsurface environments is beyond the scope of this report. These reactions are presented in numerous texts, including those by Hem and Cropper (1959), Back and Barnes (1965), Buckman and Brady (1969), Cox (1978), Freeze and Cherry (1979), Ehrlich (1981), and Smith and Tuovinen (1985). The particular problems of iron and manganese concentrations in drinking water supplies were discussed by McKee and Wolf (1963, p. 202-204), EPA (1982b), and Hileman (1980, p. 15).

In parts of the study area, excessively high concentrations of dissolved iron and manganese and oxides of these ions exceeded the recommended maximum national drinking water limits $(300 \mu \mathrm{g} / \mathrm{L} \mathrm{Fe}$, where $1,000 \mathrm{micrograms}=1$ milligram; and $50 \mu \mathrm{g} / \mathrm{L} \mathrm{Mn} ; \mathrm{EPA}, 1982 \mathrm{~b}$ ) or attained levels that are considered objectionable. Median values for all 1984-85 iron and manganese data were $30 \mu \mathrm{g} / \mathrm{L}$ Fe and $180 \mu \mathrm{g} / \mathrm{L}$ $\mathrm{Mn}$; individual values ranged from less than 3 to 7,000 $\mathrm{\mu g} / \mathrm{L}$ Fe and from less than 1 to $5,100 \mu \mathrm{g} / \mathrm{L}$ Mn. Anomalous concentrations of iron and manganese are shown in table 5 and areal trends are shown in figure $16 \mathrm{C}$.

Concentrations of both dissolved iron and manganese are consistently high in wells $56,95,96$, and 112 . Dissolved manganese concentrations are also consistently high in wells 59, 97, and 140. Large temporal fluctuations in iron or manganese concentrations are probably the result of changing subsurface environmental conditions and solubility characteristics of these metal ions. Anomalous concentrations are probably the result of anaerobic conditions that develop in soil and unsaturated rock in areas used for land disposal of potato wastewater and whey. Although the biochemical processes that produce these metal ion contaminants are well documented, contaminant movement and rates of movement through soil and rock are not fully understood. 
Reported iron contamination in water from well 105 was unique in the study area. Well 105 has been deepened several times to alleviate taste, odor, bacteria, or excessive iron concentration problems. In March 1984, the well was deepened from about 320 to $340 \mathrm{ft}$ below 1 and surface and continuous casing was installed to about $320 \mathrm{ft}$ to reduce excessive iron conditions. Iron problems reportedly were caused by contamination from the nearby potato wastewater field and were noticeably worse following aftershocks from the Mount Borah earthquake (October 1983). After the well was deepened in 1984, complaints of excessive iron stopped.

Water-quality analyses from well 105 prior to deepening in 1984 and after deepening show relatively no change in major cation, anion, or dissolved iron concentrations (Parliman, 1986, p. 100-107). Dissolved iron concentrations were $8 \mu \mathrm{g} / \mathrm{L}$ just prior to deepening and ranged from less than 10 to $70 \mu \mathrm{g} / \mathrm{L}$ after deepening. In April 1984, the dissolved iron concentration was $9 \mu \mathrm{g} / \mathrm{L}$, whereas the total iron concentration was $100 \mu \mathrm{g} / \mathrm{L}(90$ percent of the detectable iron was suspended rather than dissolved in the sample). Reports of excessive iron concentrations prior to deepening in 1984 probably were the result of casing rust rather than water contamination. Water levels in this well are generally 30 to 45 ft below land surface, which means that throughout the year there was at least a 275-ft column of water, 6 in. in diameter, in the cased part of the well. Storage capacity of the well far exceeds domestic use requirements for about 6 months each year during the nonirrigation season. Aftershocks from the Mount Borah earthquake may have shaken rust loose from the well casing and caused the reported increased iron concentrations.

Zinc is a component of soil and rock and, perhaps more importantly, will leach from galvanized pipe. Median value for all 1984-85 dissolved zinc concentrations was $51 \mu \mathrm{g} / \mathrm{L}$; individual values ranged from less than 3 to $320 \mu \mathrm{g} / \mathrm{L}$. Anomalous concentrations of dissolved $z$ inc are presented in table 5 and areal trends are shown in figure $16 \mathrm{C}$.

Concentrations of zinc were anomalously high in wells $95,96,97,101,106$, and 110 near the potato wastewater field or Collins and indicate influence of biochemical factors in and near these areas. Isolated anomalous concentrations probably are caused by biochemical or geochemical conditions in soil or rocks or by leaching of zinc from galvanized materials used in well construction, water-distribution systems, or historical landfill sites. In analyses from well 59, for example, zinc concentrations rose from 5 to $320 \mu \mathrm{g} / \mathrm{L}$ after the pump and parts of the pump column were replaced with galvanized materials. 


\section{Gasoline, Selected Trace Elements, Pesticides, and Stable Isotopes}

Water from well 89 was reported by the owners to have a distinctive and undesirable taste and odor. Water pumped from this well in 1984 had a pronounced gasoline odor and a metallic sheen on the surface. The gasoline evident in this sample could be attributed to an accidental spillage of gasoline during the 1970's from a large, above-ground storage tank immediately upgradient from well 89. The gasoline contaminant probably is being flushed from unsaturated sediments by water-table fluctuations or is infiltrating to water-yielding zones near the well.

In April 1984, water samples from five wells in areas reported to be contaminated by food-processing wastewater, landfill leachates, or stock waste were analyzed for concentrations of dissolved arsenic, cadmium, chromium, copper, lead, mercury, and selenium (table 6). Analyses indicated no contamination by these seven trace elements. The scope of investigation for these point-source contaminant indicators was limited, and the few data available do not represent areawide or temporal conditions but are included in this report as baseline information.

Pesticide analyses of potato wastewater and stableisotope analyses of potato wastewater, whey, and ground water downgradient from potato wastewater or whey applications were obtained in an effort to find contaminant "tracers," contaminants characteristic of and specific to either potato (plant origin) or whey (animal origin) wastes.

Potato-processing wastewater was analyzed for total recoverable carbamate insecticide compounds, specifically aldicarb, commonly used in potato agriculture to systemically control nematodes. No carbamate insecticide compounds were detected in the potato wastewater; consequently, no ground-water samples were analyzed for this compound.

From spring through fall 1984, water samples were obtained from 19 wells (fig. 20), as well as potatoprocessing and whey storage and distribution tanks, and were analyzed for the stable isotopes oxygen-18, relative to oxygen-16 ( $\left.{ }^{18} \mathrm{O} /{ }^{16} \mathrm{O}\right)$, and deuterium (hydrogen-2), relative to hydrogen-1 $\left({ }^{2} \mathrm{H} /{ }^{1} \mathrm{H}\right)$. Each ratio was determined for a sampled water and then related mathematically to the comparable ratio for the meteoric water standard of known isotopic composition. By convention, the computed results are expressed as delta oxygen-18 ( $\left.\delta^{18} 0\right)$ and delta deuterium $(\delta D)$, with the units of measure permil $(\% / 00)$, or parts per thousand. A negative delta value indicates that the 


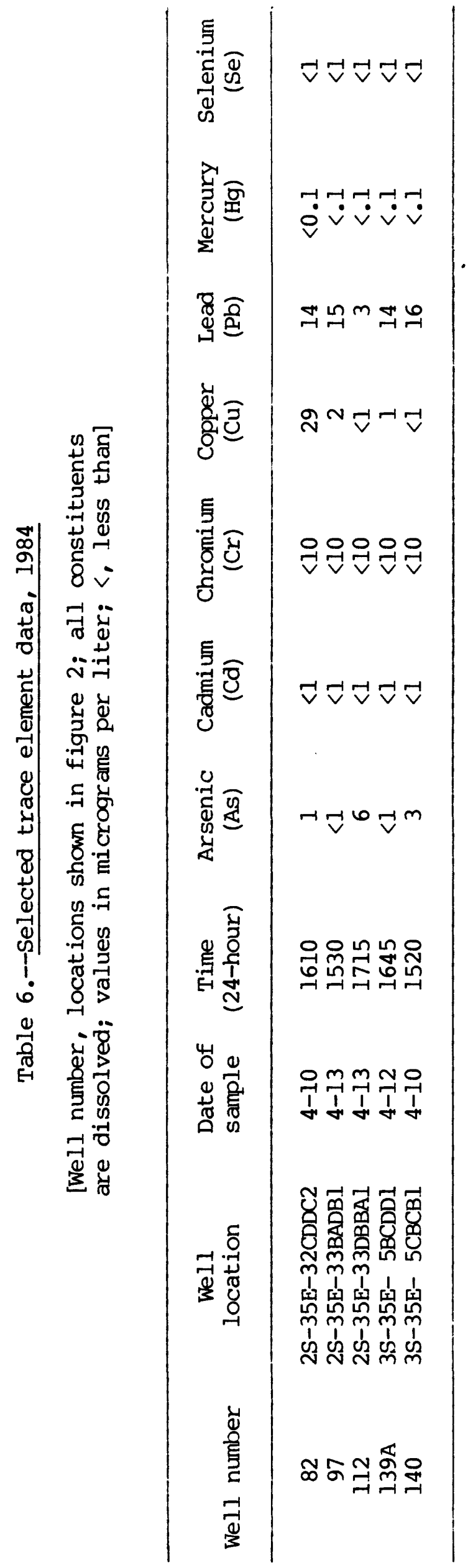




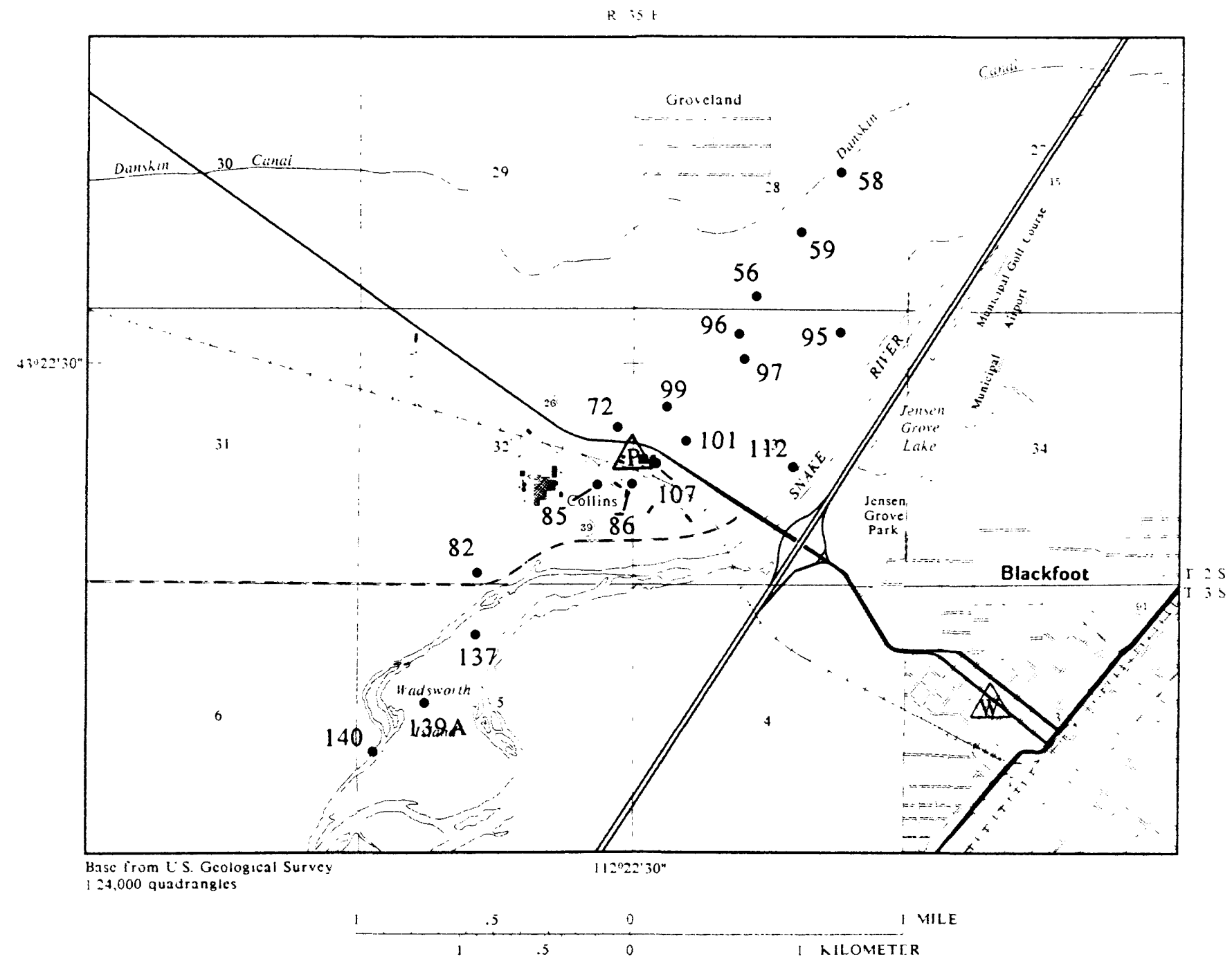

\section{EXPLANATION}

82 WELL AND NUMBER

$\triangle$ WASTEWATER SAMPLING SITE;

$P$, POTATO-PROCESSING

STORAGE TANK; W, WHEY

STORAGE TANK

Wells 14 and 147 not shown on

this map (scale too small);

locations shown in figure 2

Figure 20.--Locations of sites sampled for stable isotopes, 1984. 
sampled water is isotopically lighter than the standard (that is, the sampled water has a smaller proportion of oxygen-18 or deuterium, relative to oxygen-16 or hydrogen-1, than the standard).

Various potato-processing wastewaters and whey are heated during production. Some light isotopes of hydrogen are lost to the atmosphere as steam, and the remaining water is characterized by a greater heavy-to-light hydrogen ratio. In figure 2l, ratios of hydrogen and oxygen isotopes are plotted against the standard meteoric water line (Craig, 1961). The relation of plotted $\delta D$ and $\delta^{18} 0$ values for May 1984 indicates the following: (1) Whey is isotopically heavier (fewer negative values) than potato-processing wastewater or any other ground-water sample; (2) water from well 147 (downgradient from land used for disposal of whey during winter months) is isotopically heavier than potatoprocessing wastewater or any other ground-water sample; (3) isotopically, potato-processing wastewater is slightly heavier than most Groveland-Collins area ground water; and (4) some differences are apparent between isotopic ratios of ground water upgradient and downgradient from potato wastewater application sites, but sufficient data are not available to determine whether the differences are significant. Although figure 21 shows plots for only May 1984 analyses, plots of data from October 1984 for these sites were the same (M. G. Burns, U.S. Geological Survey, written commun., $1984)$.

As in selected trace element analyses, wells chosen for stable-isotope analyses represent a variety of ground-water conditions near areas used for land application of potatoprocessing wastewater or whey (fig. 4).

Isotope analyses from wells 95 and 147 are of particular interest because only one food-processing waste has been applied near each well (potato-processing waste near well 95 and whey near well 147). Samples from wells 14, 58, and 137 represent ground water from areas not associated with food-processing wastewater disposal. Wells 72, 85, 86, and 107 are located in the Collins area where ground water is not affected by potato or whey wastes but is affected by fertilizer spillage or sewage wastewater contamination. All other wells sampled are in or near areas used for potatoprocessing wastewater or whey disposal.

Whey reportedly was not applied to land in the study area during 1984 or 1985, but area residents stated that the wastewater had been spread periodically by tank-truck spraybar or dumping on Wadsworth Island and in the northwest corner of section 5, township 3 south, range 35 east (near 


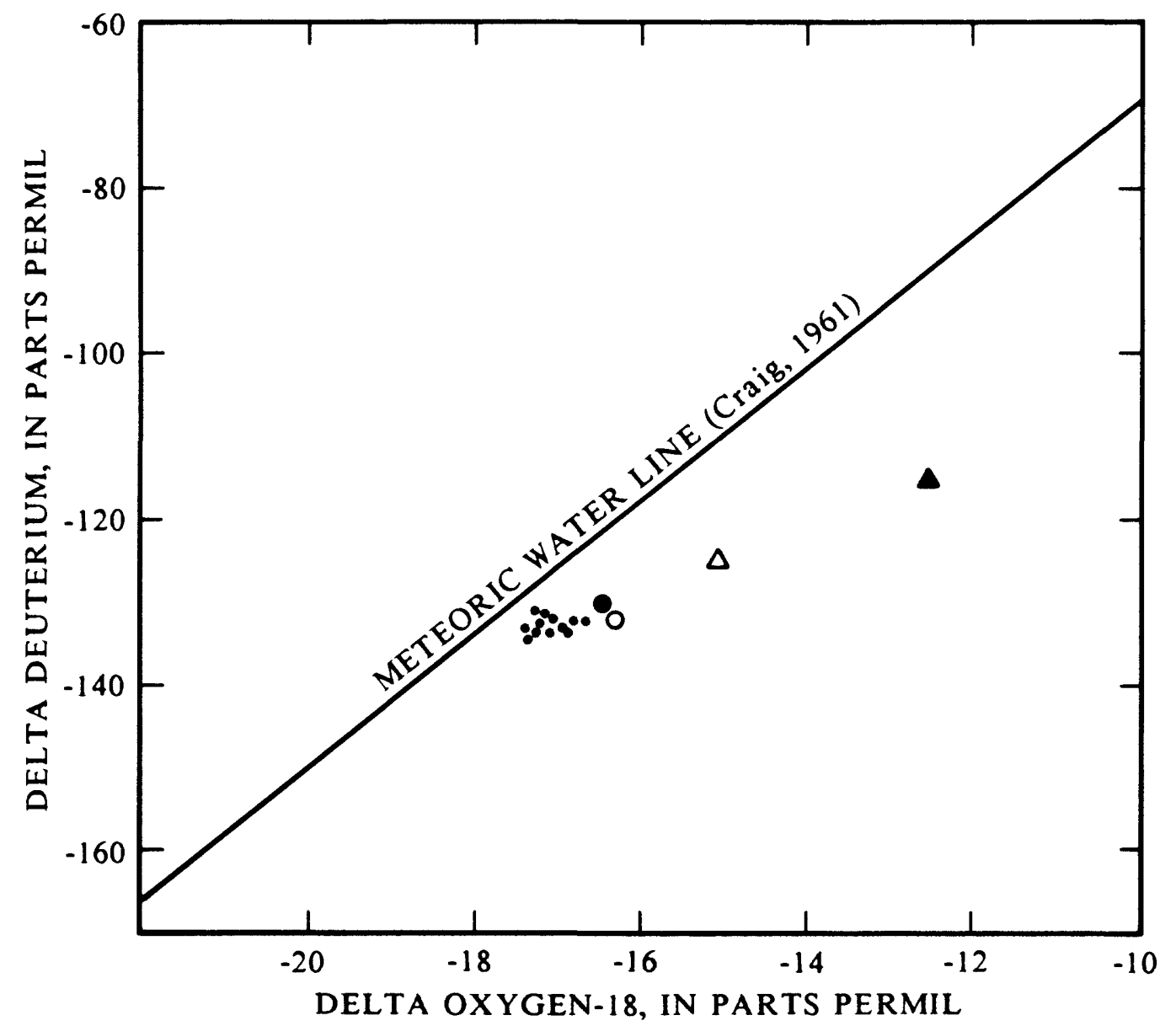

EXPLANATION

(Locations of sampling sites

show $n$ in figures 2 and 20)

$\triangle$ WHEY WASTEWATER ANALYSIS

- POTATO-PROCESSING WASTEWATER ANALYSIS

$\triangle$ ANALYSIS FROM WELL 147

O ANALYSIS FROM WELL 95

- GROUND-WATER ANALYSIS (INCLUDES WELLS

$56,58,59,72,82,96,97,101,107,112,139 \mathrm{~A}$, and 140)

Figure 21.--Relation between delta oxygen-18 and delta deuterium analyses for whey, potato-processing wastewater, and ground-water samples, May 1984. 
well 82) for many years. Well 147 is not in the GrovelandCollins area but was sampled because the well owner reported a noticeable change in taste, color, smell, and iron concentration after nearby fields were used continuously for whey disposal in winter 1983. Other than stable isotopes, results of chemical analyses from well 147 are indistinguishable from those in the Groveland-Collins area. Additional information on both potato wastewater and whey is included in the section, "Food-Processing Wastes."

Hydrogen and oxygen isotope ratio analyses may be useful in distinguishing ground-water contamination from land-surface applications of whey. The usefulness of the ratio analyses for tracing movement of contaminants from potato-processing wastewater applications is inconclusive. Additional isotope data are needed from wells hydraulically downgradient from long-term, ongoing application of whey, particularly to establish a comparative stable-isotope data base. Further information on the theory and use of stable isotopes of oxygen and hydrogen as ground-water movement tracers is included in a report by Muir and Coplen (1981).

\section{Bacteria}

Water samples were not collected or analyzed for bacterial contamination during 1984 or 1985 for the following reasons: (1) Occasional bacterial contamination of some ground-water samples has been reported in all previous ground-water quality studies of the area; (2) specific sources of bacterial contamination have not been previously defined; (3) in contaminated samples, only fecal coliform or total coliform plate counts were recorded in previous studies, not specific species of bacteria; and (4) identification of bacterial contaminant species, necessary when attempting to define specific contaminant sources, was beyond the scope of this study. However, on the basis of historical data, well owner information, and onsite inspection of well casing conditions and proximity of wells to ditches and grazing pastures, a few observations can be made concerning possible sources of bacterial contamination in the study area:

(1) Damaged well structure (primarily casing or casing cover), modifications to the well after construction, or changes in subsurface conditions near the well may allow contaminated surface water to enter some wells. (See section, "Relation of Well structure and Construction to Ground-Water Contamination.") 
(2) Historically, fecal coliform bacteria seldom were detected but total coliform bacteria often were reported as "too numerous to count." The presence of fecal coliform bacteria in ground water generally indicates contamination by animal wastes, septic-tank systems, or wastewater lagoons. The presence of total coliform bacteria indicates soil, plant, or animal sources. Absence of fecal coliform bacteria in samples with numerous total coliform bacteria indicates soil or plant sources rather than animal sources. Infiltration and leakage of surface water and irrigation water are possible sources for this type of bacterial contamination.

(3) Fecal coliform bacteria are detected by the use of specific growing media and incubation temperatures that simulate animal body environments. At least one noncoliform bacteria, Klebsiella, also will grow under these media and incubation conditions, and Klebsiella are indicators of either plant or animal bacteria sources (Vlassoff, 1977). Special laboratory techniques are needed to determine the percentage of fecal coliform and Klebsiella colonies per plate. If the ratio of Klebsiella to fecal coliform bacteria is high, the contamination source may not be animal wastes. Klebsiella/coliform ratios were not determined in previous water-quality studies of the area, and laboratory costs for bacteria ratio analyses were economically unfeasible during this study.

(4) Reports of bacterial contamination appear to increase after spring ground thaw and from mid-summer to early fall when water levels are highest. During highest water levels, several environmental factors contribute to an increase in bacteria in subsurface water. July and August are often periods of sparse precipitation and heavy irrigation. Bacteria may be flushed into subsurface materials by heavy field and yard irrigation. Irrigation water also may leak from canals and ditches, down the sides of well casings, or into damaged well casings. During periods of peak ground-water levels, sediments several feet thick overlying the basalt aquifer may become saturated, and bacteria that usually are filtered out by sediments before reaching the ground-water system may be flushed into the system (fig. 15). Increasing complaints of bacterial contamination during late summer and early fall may be related to heavy irrigation of fields after crops have been harvested and crop residues plowed under.

(5) Black, stringy, algae-like growth reported in local household plumbing and well pumps may be caused by species of iron bacteria. Iron bacteria are common in 
ground water open to air, such as in a well borehole, when sufficient iron or manganese is present, along with either organic compounds or bicarbonate-carbon dioxide dissolved in the water. These bacteria characteristically produce a fibrous "slime" that may rapidly clog well screens and reduce well pump efficiency. Clogging, casing corrosion, and water-quality degradation associated with iron-precipitating bacteria are discussed in a report by Smith and Tuovinen (1985), and the mechanisms of microbial oxidation of both iron and manganese are described in a report by Ehrlich (1981).

\section{Locations and Probable Sources} of Ground-Water Contamination

Approximate locations of distinctive ground-water contamination were defined (fig. 22) on the basis of areal and temporal water-quality trends, 1984-85 data, and reports of water-quality problems prior to 1984. A summary of probable contaminant sources is presented in table 7 . Predictably, these areas of ground-water contamination are closely associated with type of land use (fig. 4).

\section{RELATION OF WELL STRUCTURE AND CONSTRUCTION TO GROUND-WATER CONTAMINATION}

Well structure or construction may provide routes for movement of contaminants from 1 and surface or unsaturated soil and rock to the ground-water system. Contaminated water can enter wells through cracks or breaks in casing covers or casing, migrate downward through fill materials surrounding the casing, or move directly into uncased parts of the borehole.

Several wells inventoried in 1984 and 1985 had cracked or broken casing covers or casings. Many plastic accesshole plugs in casing covers were cracked or broken and most disintegrated when used. Sanitary seals on several wells were damaged or missing and, in a few instances, casing covers were only a few inches above land surface, particularly where wells were located in pits or where the land surface had been built up since well construction.

One well with a history of bacterially contaminated water is located in a shallow, concrete-sided pit at the low point of a large, paved driveway. When the well was inventoried in 1984, the pit was loosely covered with wooden planks, and the top of the casing was nearly flush with the dirt floor of the pit. A flat steel plate was welded to the 
R. ij $\mathrm{E}$

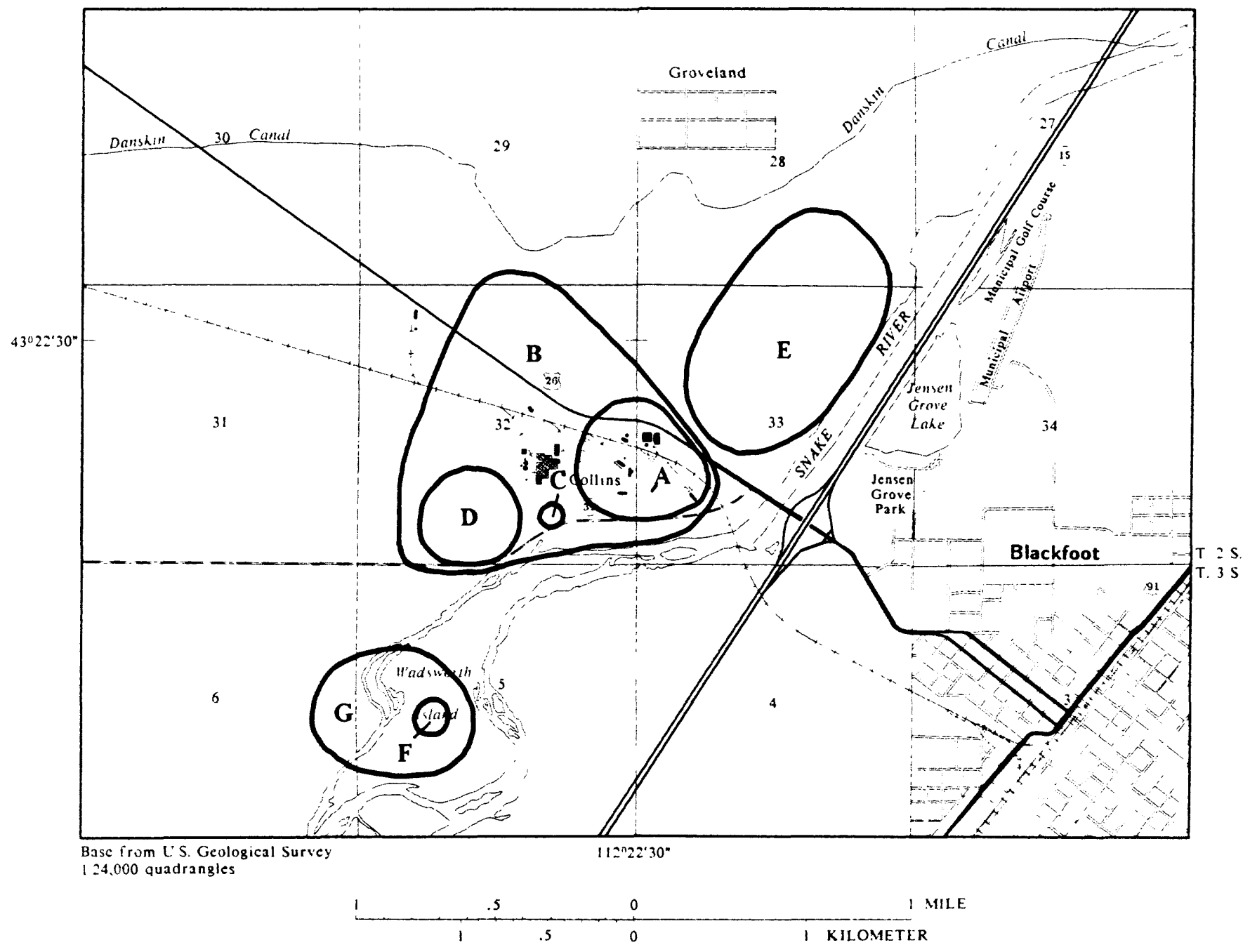

Figure 22.--Approximate locations of areas with ground-water contamination, 1984-85. 


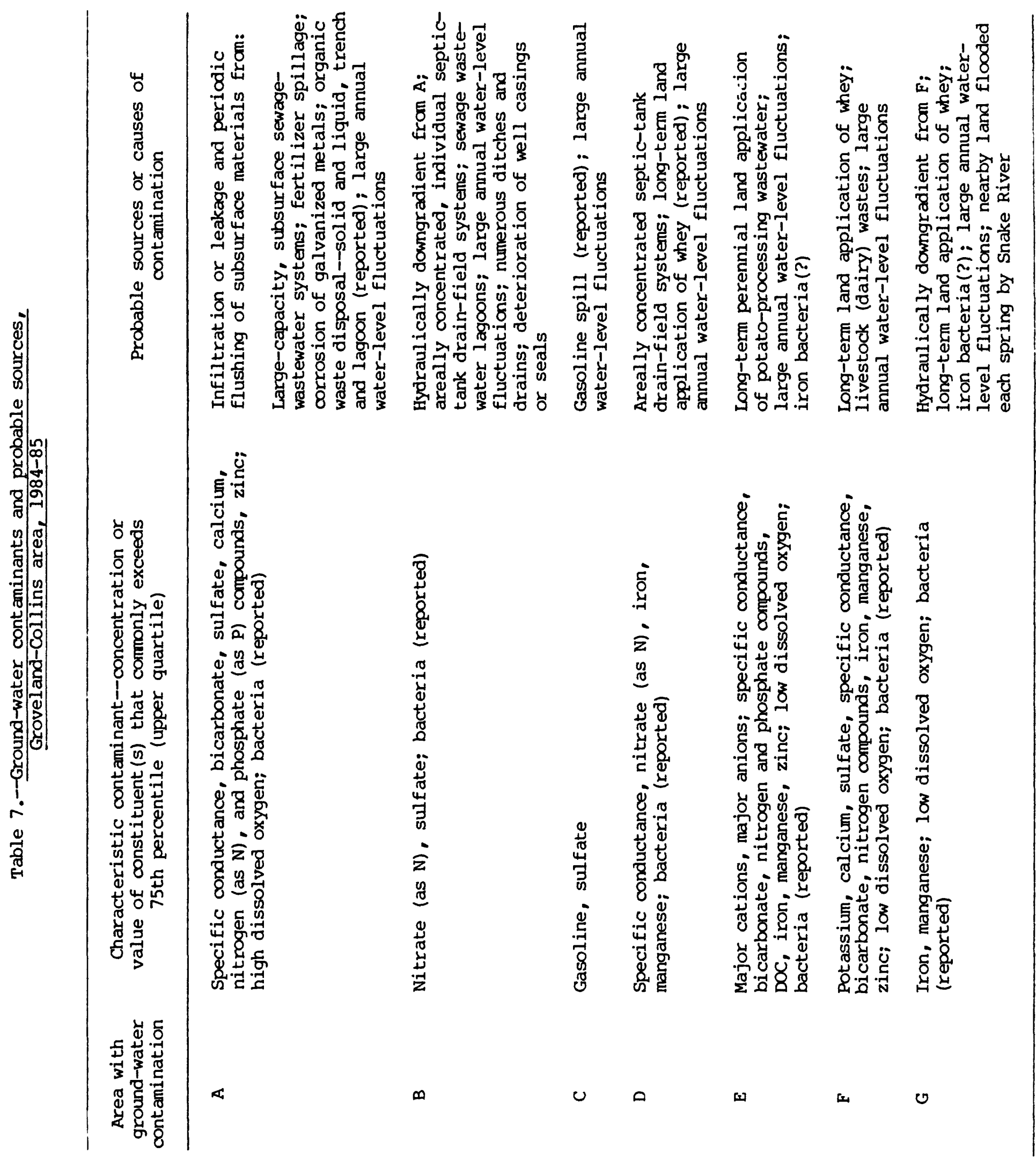


casing as a cover, but one section of casing was broken just below the cover weld. Runoff from yard, garage, and driveway areas, including pet wastes, flowed into the well pit and into the well. Not only was water from this well contaminated periodically, but also the potential exists for this point source of contamination to affect quality of water hydraulically downgradient.

In Idaho, wells are required to have a minimum of $18 \mathrm{ft}$ of casing below land surface (Idaho Department of Water Resources, 1978, p. 4). In the study area, many wells are cased to the first basalt, commonly 20 to $40 \mathrm{ft}$ below 1 and surface. Total depth of casing varies from site to site, but few wells are cased more than a few feet into basalt (refer to fig. 7 for examples of domestic, commercial, and public supply well construction). Surface seal requirements may be fulfilled by shoveling bentonite powder around the well casing as it is emplaced in the borehole, and grouting is not used routinely between the borehole and the lower end of the casing to prevent downward or upward leakage of water. Land-surface or subsurface contaminants infiltrating through soil and unsaturated soil and rock may move rapidly through displaced rock in the annular space between casing and borehole. Numerous, ungrouted older wells may provide pathways for contaminant leakage and may be prone to contamination from sediment flushing during periods of high water levels.

In new well construction, grouting of the annular space at the basalt/sediment contact may deter leakage of local contaminants to the open well hole, particularly during seasonal high water levels. Adding a cement grout apron around the well casing at land surface, deepening shallow wells, adding casing, and grouting annular space between casing and borehole could improve the quality of water in some existing wells. Repair of obvious well structure damage may alleviate water-quality problems in a few wells.

\section{FOOD-PROCESSING WASTES}

Biochemical effects of land-surface disposal of potato-processing wastewater on soil, unsaturated and saturated rock, and water are well documented (Talburt and Smith, 1967; Smith, Gilbert, and Miller, 1976, 1978; and Smith, Robbins, Bondurant, and Hayden, 1977, 1978). Biochemical effects of land disposal of whey also have been researched and results published (Watson and others, 1977; Kelling and Peterson, 1981), but not to the same extent as potato wastes, probably because the quantities of whey and areal magnitude of waste-disposal problems are much smaller than those associated with potato-processing wastewater. 
In the Groveland-Collins area, disposal of potatoprocessing wastewater has been relatively well documented and regulated, but land disposal of whey has received little, if any, attention. Documented information on whey disposal sites, methods of whey disposal, or quantities of whey per time period applied to any one site is not available or is incomplete, but some reported information is available from area residents.

\section{Wastewater Data}

Chemical character of food-processing wastes, especially potato wastewater, is highly variable. Analyses of whey may differ slightly with types of cheese produced and quality of milk used, but the overall chemical character of the wastewater remains relatively constant. Chemical character of potato wastewater does not remain the same throughout the year and may change significantly over short periods of time. Refer to Talburt and Smith, (1967, p. 555-574); Smith and others (1977); Watson and others (1977, p. 26); Smith, Robbins, Bondurant, and Hayden (1978); and Kelling and Peterson (1981, p. 1-2) for information and discussions on chemical quality of whey and potato wastewater.

Quality of potato wastewater is affected by numerous short-term and long-term changes inherent in potato manufacturing. Starch, flake, slice, and whole potato (fresh pack) processes produce varying quantities and qualities of wastewater, and not all (or none) of these processes are in operation at any one time during the year. In general, from crop harvest in about october until stored potato supplies are depleted in about July, most or all products are being processed continuously. During August and September, production is shut down and water for wastewater field irrigation is supplied directly by plant wells. As types of product and production methods (caustic peeling, steam peeling, or abrasive peeling and organic solids removal, for example) change, the volume and quality of wastewater from different sources may vary significantly.

Samples of potato-processing wastewater were collected periodically from 1974 to 1983 by Idaho Department of Health and Welfare personnel and were analyzed at the Bureau of Laboratories, Boise. Potato-processing wastewater and whey samples were collected during 1984 and 1985. All whey samples were obtained from a storage/distribution tank at the cheese-processing plant in Blackfoot.

Pre-1984 and 1984-85 analyses of potato-processing wastewater and 1984 analyses of whey are shown in table 8, compiled from Idaho Department of Health and Welfare and 


\section{Headnotes for table 8}

Sampling location:

$\mathrm{PH}$, booster pump house in potato wastewater field

ST, storage/distribution tank at processing plant

WL, irrigation wheel-line in potato wastewater field

Collecting agency:

H, Idaho Department of Health and Welfare, Southeastern District Health Department

E, Idaho Department of Health and Welfare, Division of Environment

GS, U.S. Geological Survey, Water Resources Division

Other notations:

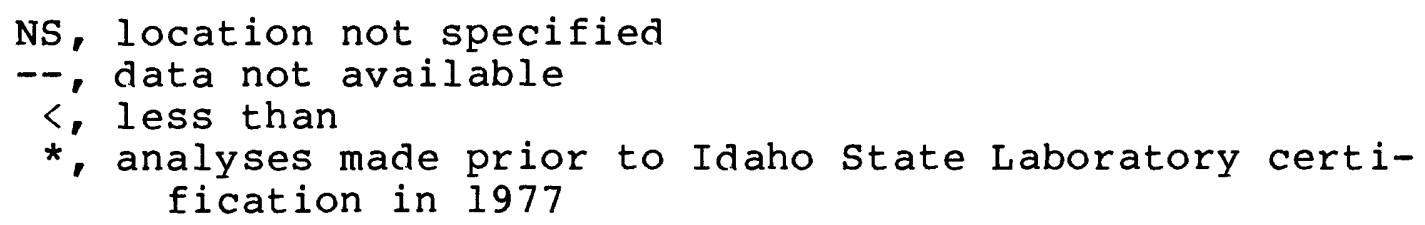




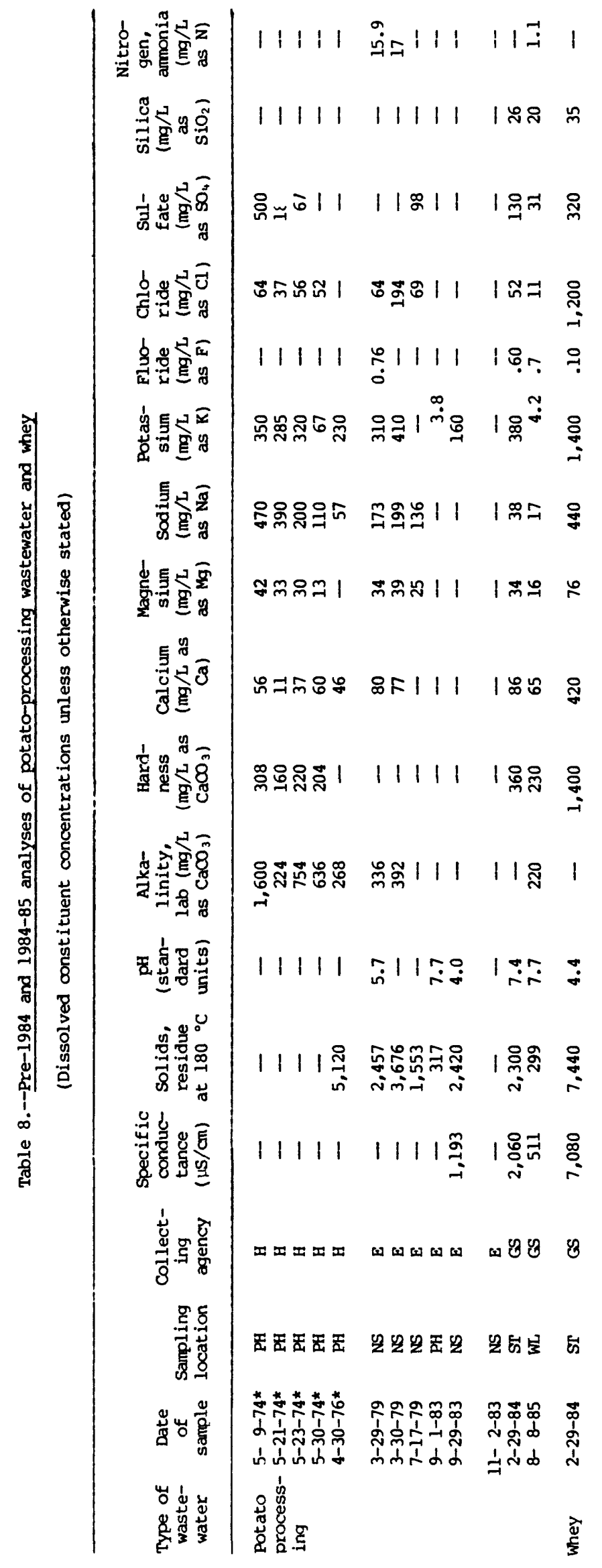




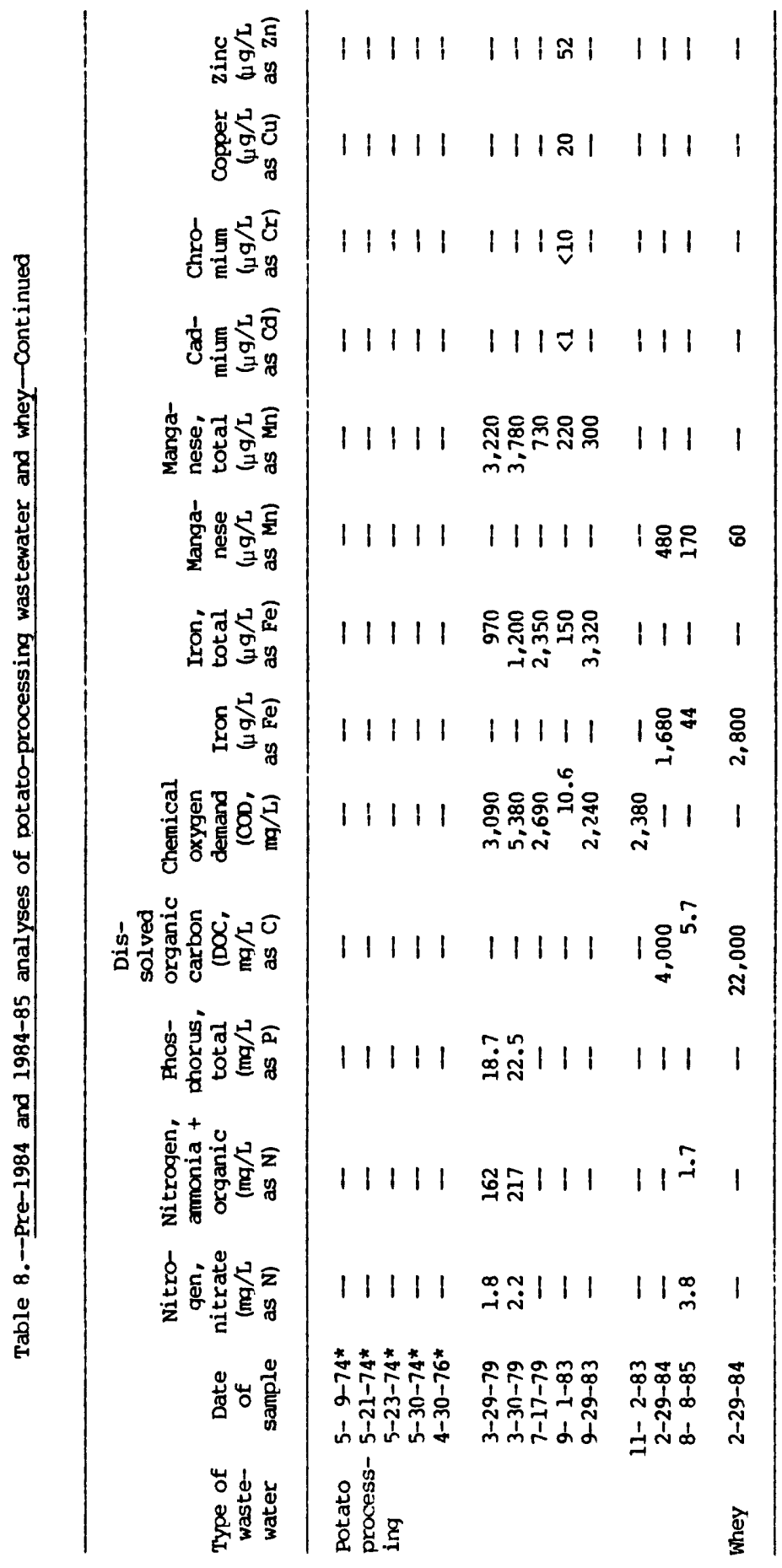


U.S. Geological Survey records. Data in table 8 reflect wastewater quality during periods of varying product processing, plant production, and production methods and should be considered reference or baseline data only.

Graphs of total daily potato-processing wastewater discharge and daily COD (chemical-oxygen demand) are shown in figure 23 for the period January 1984 through July 1985. COD is a measure of the chemically oxidizable material in water and provides an approximation of the amount of organic material present. Data in figure 23 were compiled from field and laboratory records maintained by the potatoprocessing plant. Comparative records for whey were not tabulated (see section, "Land Application of Wastewater").

Extreme variability of discharge rates and wastewater quality is evident. Daily records showing relatively high discharge with relatively low COD, for instance, probably indicate a high percentage of well water in total wastewater volume for that day.

\section{Land Application of Wastewater}

Since the early $1970^{\prime} \mathrm{s}$, potato-processing wastewater was applied year-round by set-head (standing-head) sprinklers to land near wells 95 and 97. In the late 1970's, land adjoining this original field was filled and leveled and is used periodically for flood- or wheel-line spreading of wastewater. Currently, potato wastewater is applied throughout the year to land near wells 112,97 , and 95, and to land near wells M5, 59, M8, and M9 from about April to November.

The field is divided into subareas by levees. Wastewater applications are moved from one subarea to another on approximately a 12-hour rotation schedule. Alfalfa and hay are the primary crops grown in most subareas and are not irrigated during crop harvesting. Soil is tilled in each subarea at least once a year.

Field-management practices are complex and are subject to change throughout the year. Some practices that may affect geochemical processes (and ultimately, ground-water quality) in soils and rock underlying the field include amount of wastewater and quality of wastewater applied to each subarea, period and pattern of wastewater rotation among subareas, method of wastewater application, type of soil and land topography, type of crop and amount of time a subarea is dry for crop harvest, and soil tilling (deep, shallow, number of times each year, time of the year). 


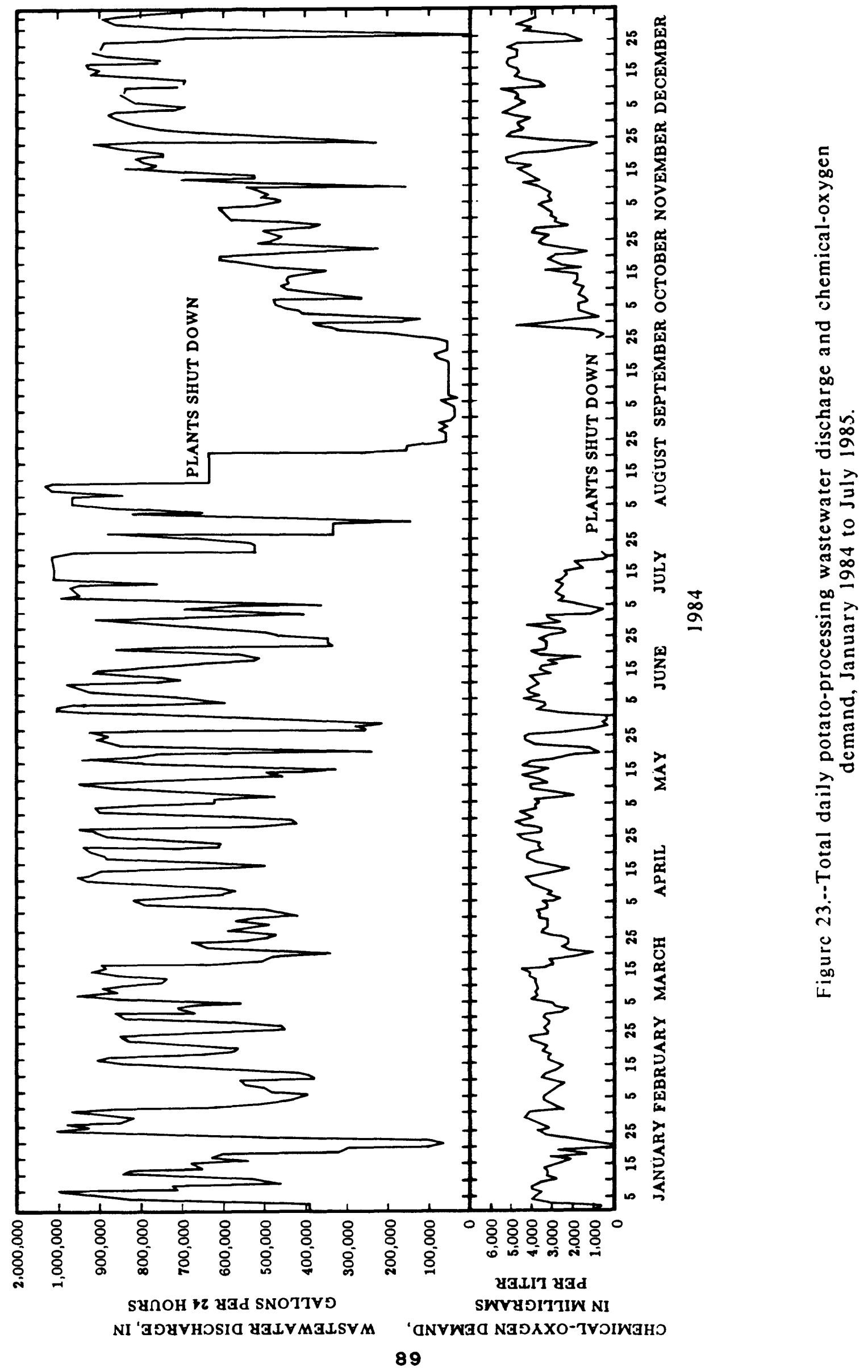




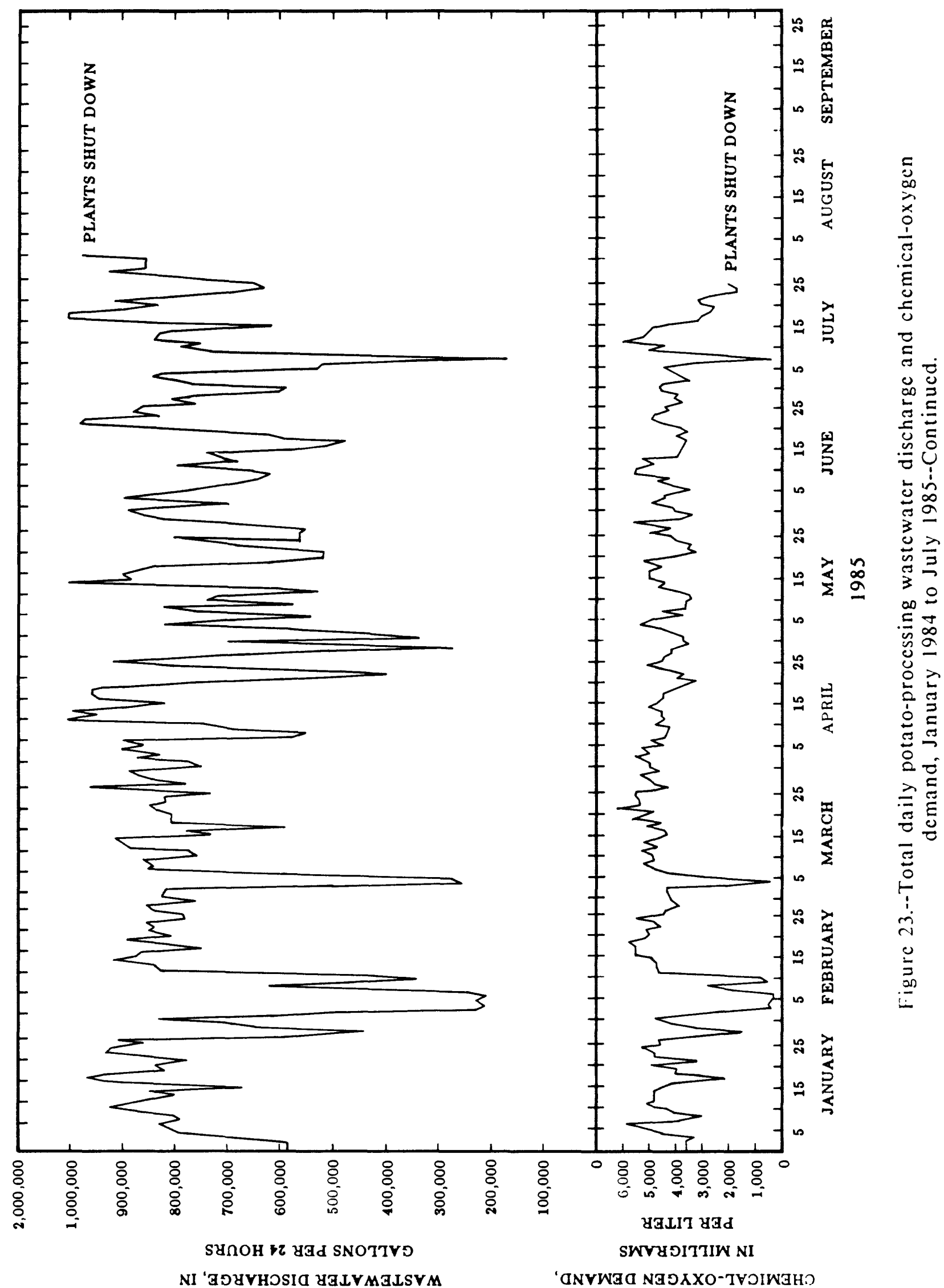


Prior to the fall of 1985, whey was distributed throughout the year to various fields near Blackfoot by tank trucks (about 3,500 gal per tank load and 7 to 13 tank loads per day, or about $10,000,000$ gal of whey annually). In 1985, whey was no longer spread by spraybar or dumping but was jetted over selected fields by a water cannon mounted on a tank truck, which applied a thin film of wastes over large areas (G. J. Hopson, Idaho Department of Health and Welfare, oral commun., 1985). Updated procedures for whey application also include maximum limits for whey load per year and total whey load for any given land area.

During this study, several observations were made about land-application practices and effects of foodprocessing wastewater used for fertilizer and irrigation:

(1) Organic and inorganic constituent concentrations are, overall, higher in whey than in potato wastes.

(2) On a per-day basis, quantities of whey are small compared with quantities of potato wastewater.

(3) Application of large volumes of wastes for extended periods of time creates biochemical conditions in subsurface rock that may produce localized ground-water contamination.

(4) Application of small volumes of highly concentrated wastes over relatively small acreages, followed by flood irrigation, for extended periods of time produces the same subsurface biochemical effects as large volumes of less concentrated wastes (or highly variable concentrations of wastes).

(5) Discharging concentrated wastes into ditches, canals, or gravel pits rather than distributing wastes by spraying may result in more pronounced ground-water contamination.

(6) Combinations of wastewater quantity, quality, and environmental conditions are rarely, if ever, constant in any one area.

(7) Effects of wastewater disposal on ground-water quality are most significant immediately after ground thaw.

(8) Chemical and physical properties of soil and unsaturated soil and rock in areas used for wastewater disposal are not well documented.

(9) Wastewater and land-management practices that effectively control contaminant formation in one part of a 
field may not be effective in other areas of the same field or in that same area under differing environmental conditions.

Land-management practices that may be helpful when considering a disposal program for food-processing wastewater include (1) maintenance of accurate, detailed records of wastewater volume, periodic quality, and land application information: (2) areal study of soil and unsaturated soil and rock in areas used for wastewater disposal; (3) periodic monitoring of subsurface water conditions at numerous sites representing different soils, unsaturated rock, and land-use conditions: (4) determination of localized subsurface and ground-water movement patterns, including annual changes in water levels near waste-disposal sites; and (5) additional wastewater treatment or alternative disposal practices used during months when soil is frozen.

\section{DEVELOPMENT OF A GROUND-WATER MODEL AND FURTHER STUDIES}

Development of a ground-water model to evaluate effects of land application of organic wastewater and organic solute-loading rates on subsurface water quality is not feasible at this time. Information on soils, unsaturated soil and rock, subsurface water movement, and ground-water or recharge-water quality is sparse for most areas used for wastewater disposal but is critical to understanding waterquality conditions in any area. Development of a model without sufficient data to adequately define system variables could result in misleading or inaccurate conclusions.

Further studies are needed to define more accurately the sources and extent of specific contaminants, particularly in relation to land application of wastewater. Stable isotopes could be used to define sources of organic wastewater contamination. Stable-isotope data collected during this study were sparse but did show significant differences between whey and potato wastewater samples. Further study of isotope movement characteristics may help define both vertical and horizontal movement of contaminants.

Further study of soil and unsaturated rock by experts in soil chemistry and methods of soil analyses would provide valuable information on localized conditions and mechanisms of contaminant movement in areas used for wastewater disposal. Data provided by a study of unsaturated soil and rock would be helpful in establishing land-management practices that would most effectively control contaminant formation. 
A comprehensive study of ground-water bacteria would help define specific sources of localized, chronic bacterial contamination in the Groveland-collins and surrounding areas. Areal and temporal data on specific species of bacteria present in water-yielding zones would determine whether bacteria originated in soil, plant, livestock, or sewage wastewater environments.

\section{SUMMARY}

The movement, chemistry, and quality of subsurface water in the Groveland-Collins area near Blackfoot, Idaho, are controlled by composition, structure, and distribution of soil and rock; chemical character, volume, and seasonal variation of sources of recharge; and biochemical reactions in unsaturated and saturated rock. Long- and short-term land- and water-use activities near the Groveland-collins area cause localized ground-water contamination that may make water from some water-yielding zones unsuitable for use.

Principal rock units in the study area are river-, lake-, or windblown-sediment deposits and basalt of the Quaternary Snake River Group. Sediment comprises coarse lenses or beds of clay, silt, sand, gravel, or cobbles, which are poorly sorted and gradational, both vertically and horizontally. Basalt is fractured and jointed to massive and includes interbeds of sediment, cinders, or basalt rubble. The basalt surface is undulating with areas of relatively high relief and is overlain by sediment. In many areas the basalt is immediately overlain by an impervious layer of clay or silt.

Hydraulic characteristics of unsaturated and saturated rocks are highly variable and generally undefined in the study area. Principal water-yielding zones are in basalt under either confined or unconfined conditions. Water infiltrating through unsaturated rock may be perched in localized areas above lenses of fine-grained sediment. Water in basalt moves generally northwestward. Surface- and subsurface-water relations are complex and not well defined in current and historical snake River channel materials, but water-level data indicate that some water in basalt moves under the river. Water in perched zones near Jensen Grove Lake moves northwestward, laterally or downward, but not under the river. Water in perched zones northwest of the river moves generally northwestward away from the river.

Recharge to the ground-water system is primarily from infiltration or leakage of surface water, applied irrigation water, and precipitation. Recharge from surface-water 
sources is most significant during the irrigation season from about May to October and produces areawide water-level fluctuations that may exceed $15 \mathrm{ft}$. Precipitation recharge is most significant in the spring when the ground thaws.

Clay lenses in unsaturated rock, particularly those overlying the basalt surface, impede the downward movement of water, but open well boreholes or leakage around casings may allow movement of water (including contaminants) to water-yielding zones. Movement of water through unsaturated and saturated rock or between water-yielding zones in basalt is not well defined or understood. Subsurface basalt ridges impede lateral movement of water in localized areas. Ground water pools temporarily behind these ridges and anomalously high water levels result.

Land and water uses in the Groveland-Collins area that directly or indirectly affect ground-water quality include historical landfills or trench disposal of solid organic wastes; bulk gasoline and fertilizer storage and distribution; high densities of small-capacity septic-tank drainfield or seepage-pit systems; large-capacity septic-tank drain field, seepage pit, or sewage wastewater lagoons; irrigation runoff; dairy and livestock production wastes; and land application of food-processing wastes, including potato-processing wastewater and whey. Large temporal changes or anomalously high concentrations of chemical constituents in ground water may indicate contamination from land-use activities.

Ground water in the study area is generally suitable for most uses, contains predominantly calcium, magnesium, and bicarbonate ions, and characteristically has more than $200 \mathrm{mg} / \mathrm{L}$ hardness (hard or very hard water). In parts of the area, however, ground water contains chemical constituents or bacterial concentrations that could restrict the water's use. High alkalinity, hard or very hard water, or highly mineralized water may be esthetically or economically restrictive. Nitrate-nitrogen concentrations exceed drinking water limits in only a few samples but are anomalously high in many samples. Concentrations of dissolved iron and manganese exceed drinking water limits in localized areas, and dissolved ammonium, organic nitrogen, organic carbon, and $z$ inc concentrations are anomalously high in a few areas. Bacterial concentrations are reported to exceed drinking water limits in some locations. Sources of excessive bacteria have not been determined, but most bacterial contamination probably is caused by infiltration or leakage of irrigation water rather than by sewage wastes.

Ground water in localized areas is contaminated predominantly by infiltration of sewage wastewater or liquid fertilizer spillage and land application of food-processing wastewater. Contamination from varying sources is either 
periodic or persistent and generally is limited in areal extent. Contaminant concentrations in many areas are highest immediately after ground thaw in April. Contamination is most frequent during spring and summer months and least frequent during winter months. Rising water levels during the irrigation season flush contaminants from previously unsaturated rock into the ground-water system. Little information is available on movement of contaminated water between unsaturated and saturated rock or between water-yielding zones in basalt.

Median and maximum (maximum given in parentheses) concentrations or values of selected constituents are 485 $(1,450) \mu \mathrm{S} / \mathrm{cm}$ specific conductance, 260 (630) $\mathrm{mg} / \mathrm{L}$ bicarbonate as $\mathrm{HCO}_{3}, 210(370) \mathrm{mg} / \mathrm{L}$ hardness as $\mathrm{CaCO}_{3}, 0.55$ (11) $\mathrm{mg} / \mathrm{L}$ nitrate-nitrogen, 1.1 (4.4) $\mathrm{mg} / \mathrm{L}$ dissolved organic carbon, $30(7,000) \mu \mathrm{g} / \mathrm{L}$ dissolved iron, $180(5,100) \mu \mathrm{g} / \mathrm{L}$ manganese, and 51 (320) $\mu \mathrm{g} / \mathrm{L}$ zinc. Dissolved-oxygen concentrations range from $8.9 \mathrm{mg} / \mathrm{L}$ in uncontaminated areas to $0 \mathrm{mg} / \mathrm{L}$ in areas where food-processing wastewater is applied to the land surface.

Hydrogen and oxygen isotope ratio analyses may be useful in differentiating potato-processing wastewater from whey contamination in areas where both wastes are applied to the land surface.

Locally, well structure or construction provides routes for movement of contaminants from land surface or unsaturated soil and rock to the ground-water system. Contaminated water enters wells through cracks or breaks in casing or casing covers, migrates downward through fill materials surrounding the casing, or moves directly into uncased parts of the borehole. Ungrouted wells may provide pathways for contaminants and may be prone to contamination from sediment flushing during seasonal high water levels.

Chemical character of food-processing wastes, especially potato wastewater, is highly variable and may change significantly over short periods of time. Over extended periods of time and on relatively small acreages, application of large volumes of wastewater creates biochemical conditions in soil and unsaturated rock that may produce localized ground-water contamination. Application of small volumes of highly concentrated wastes followed by flood irrigation produces the same subsurface effects as large volumes of less concentrated wastes (or highly variable concentrations of wastes). Effects of wastewater disposal on ground-water quality are most significant immediately after ground thaw. Chemical and physical properties of soil and unsaturated rock in areas used for wastewater disposal are not well documented. 
Development of a ground-water model to evaluate effects of land application of organic wastewater and organic solute loading rates on subsurface water quality is not feasible at this time because of insufficient data. 
Back, William, and Barnes, Ivan, 1965, Relation of electrochemical potentials and iron content to ground-water flow patterns: U.S. Geological Survey Professional Paper $498-\mathrm{C}, 16 \mathrm{p}$.

Bingham County, 1981, Bingham County ground water project: Blackfoot, Idaho, U.S. Environmental Protection Agency Grant, Water Quality Program, $414 \mathrm{p}$.

Buckman, H.O., and Brady, N.C., 1969, The nature and properties of soils: New York, Macmillan Company, $653 \mathrm{p}$.

Burr, Gwen, 1983, Guidelines for land application of municipal and industrial wastewaters: Boise, Idaho Department of Health and Welfare, Division of Environment, $29 \mathrm{p}$.

Canter, L.W., and Knox, R.C., 1985, Septic tank system effects on ground water quality: Chelsea, Mich., Lewis Publishers, Inc., $336 \mathrm{p}$.

Carlson, R.C., 1980-82, water District 01 annual reports, Snake River and tributaries above Milner, Idaho: Idaho Falls, Idaho Department of Water Resources.

Castelin, P.M., 1974, Water resources of the AberdeenSpringfield area, Bingham and Power Counties, Idaho: Idaho Department of Water Administration, Water Information Bulletin $36,33 \mathrm{p}$.

Cox, E.R., 1978, Iron in water near wastewater lagoons in Yellowstone National Park, Wyoming: U.S. Geological Survey Journal of Research, v. 6 , no. 3, p. 319-324.

Craig, Harmon, 1961, Isotopic variations in meteoric waters: Science, v. 133, p. 1702-1703.

Drever, J.I., 1982, The geochemistry of natural waters: Englewood Cliffs, N.J., Prentice-Hall, Inc., 388 p.

Ehrlich, H.L., 1981, Geomicrobiology: New York, Marcel Dekker, Inc., p. 165-249.

Forsgren-Perkins Engineering, 1982, Bingham County westside study for the communities of Collins, Groveland, Moreland, and Riverside: Rexburg, Idaho, U.S. Environmental Protection Agency, Project no. C-16 0371-01, $120 \mathrm{p}$.

Freeze, R.A., and Cherry, J.A., 1979, Ground water: Englewood Cliffs, N.J., Prentice-Hall, Inc., 604 p. 
Gi11, M.A., 1984, Water-table rise due to infiltration from canals: Journal of Hydrology, v. 70 , no. 1-4, p. $337-352$.

Greeley, Ronald, 1982, The Snake River Plain, Idaho--representative of a new category of volcanism: Journal of Geophysical Research, v. 87, no. B4, p. 2705-2712.

Heath, R.C., 1983, Basic ground-water hydrology: U.S. Geological Survey Water-Supply Paper 2220,84 p.

Hem, J.D., 1985, Study and interpretation of the chemical characteristics of natural water ( $3 d$ ed.): U.S. Geological Survey Water-supply Paper 2254,263 p.

Hem, J.D., and Cropper, W.H., 1959, survey of ferrousferric chemical equilibria and redox potentials: U.S. Geological survey Water-Supply Paper 1459-A, $268 \mathrm{p}$.

Herbert, L.R., Cruff, R.W., and Waddell, K.M., 1985, Seepage study of six canals in salt Lake County, Utah, 1982-83: Salt Lake City, Utah Department of Natural Resources, Technical Publication no. 82, 95 p.

Hileman, L.H., 1980, Iron and manganese content of rural domestic water: Fayetteville, Ark., Arkansas Farm Research, v. XXIX, no. 1, p. 15 .

Idaho Department of Health and Welfare, 1985, Snake Plain aquifer technical report: Boise, Idaho, Division of Environment, $117 \mathrm{p}$.

Idaho Department of Water Resources, 1978, Minimum well construction standards, rules and regulations: Boise, Idaho, $16 \mathrm{p}$.

Johnson Division, Inc., 1966, Ground water and wells: st. Paul, Minn., Edward E. Johnson, Inc., 440 p.

Kelling, K.A., and Peterson, A.E., 1981, Using whey on agricultural land--a disposal alternative: Madison, Wis., University of Wisconsin, Agricultural Bulletin A3098, $6 \mathrm{p}$.

Klein, J.M., and Bradford, W.L., 1980, Distribution of nitrate in the unsaturated zone, Highland-East Highlands area, San Bernardino County, California: U.S. Geological Survey Water-Resources Investigations 80-48, $70 \mathrm{p}$.

Krauskopf, K.B., 1967, Introduction to geochemistry: New York, McGraw-Hill, 721 p. 
Leenheer, J.A., Malcolm, R.L., McKinley, P.W., and Eccles, L.A., 1974, Occurrence of dissolved organic carbon in selected ground-water samples in the United States: U.S. Geological Survey Journal of Research, v. 2, no. 3 , p. 361-369.

McKee, J.E., and Wolf, H.W., eds., 1963, Water quality criteria (2d ed.): Sacramento, Calif., California State Water Quality Control Board, $548 \mathrm{p}$.

Muir, K.S., and Coplen, T.B., 1981, Tracing ground-water movement by using the stable isotopes of oxygen and hydrogen, Upper Penitencia Creek alluvial fan, Santa Clara Valley, California: U.S. Geological survey Water-Supply Paper 2075, 18 p.

Mundorff, M.J., Crosthwaite, E.G., and Kilburn, Chabot, 1964, Ground water for irrigation in the snake River basin in Idaho: U.S. Geological Survey Water-Supply Paper 1654,224 p.

National Academy of Sciences, National Academy of Engineering, 1973 [1974], Water quality criteria 1972: Washington, Government Printing Office, 594 p.

National Oceanic and Atmospheric Administration, 1970-84, Climatological data, annual summaries, Idaho: Asheville, N.C.

Netz, K.E., 1980, Evaluation of canal seepage in the Snake River fan, Bonneville and Bingham Counties, Idaho: Moscow, University of Idaho, M.S. thesis, 66 p.

Nordell, Eskel, 1961, water treatment for industrial and other uses: New York, Reinhold Publishing Corp., $598 \mathrm{p}$.

Parliman, D.J., 1986, Compilation of well and ground-water quality data for selected wells near Blackfoot, Idaho: U.S. Geological Survey Open-File Report 86-127, 113 p.

Piper, A.M., 1944, A graphic procedure in the geochemical interpretation of water analyses: American Geophysical Union Transactions, v. 25, p. 914-923.

Robinette, M.S., and Matzner, R.A., 1980, Electrical resistivity investigations of the Springfield-Blackfoot area, Idaho: U.S. Bureau of Water and Power Resources Service, $42 \mathrm{p}$.

Salzmann, R.A., and Harwood, J.O., 1973, Soil survey of Bingham area, Idaho: U.S. Soil Conservation Service, $123 \mathrm{p}$. 
Scott, W.E., 1981, Surficial geologic map of the eastern Snake River Plain and adjacent areas, $111^{\circ}-115^{\circ}$, Idaho and Wyoming: U.S. Geological Survey Open-File Report 81-507, scale $1: 250,000,3$ sheets.

Smith, A.S., and Tuovinen, O.H., 1985, Environmental analysis of iron-precipitating bacteria in ground water and wells: Ground Water Monitoring Review, v. 5, no. 4 , p. 45-52.

Smith, J.H., Gilbert, R.G., and Miller, J.B., 1976, Redox potentials and denitrification in a cropped potato processing waste water disposal field: Journal of Environmental Quality, v. 5, no. 4, p. 397-399.

---- 1978, Redox potentials in a cropped potato processing waste water disposal field with a deep water table: Journal of Environmental Quality, v. 7, no. 4, p. 571-574.

Smith, J.H., Robbins, C.W., Bondurant, J.A., and Hayden, C. W., 1977, Treatment of potato processing wastewater on agricultural land--water and organic loading, and the fate of applied plant nutrients, in Loehr, R.C., ed., Land as a waste management alternative, Proceedings of the 1976 Cornell Agricultural Waste Management Conference: Ann Arbor, Mich., Ann Arbor Science Publishers, Inc., p. 769-781.

---- 1978, Treatment and disposal of potato processing waste water by irrigation: U.S. Department of Agriculture Conservation Research Report $22,37 \mathrm{p}$.

Spruill, T.M., 1983, Relationship of nitrate concentrations to distance of well screen openings below casing water levels: American Water Resources Association, Water Resources Bulletin, v. 19, no. 6, p. 977-981.

Stacha, J.H., and Pontius, F.W., 1984, An overview of water treatment practices in the United States: American Water Well Association Journal, October 1984, p. 73-85.

Stewart, E.L., 1983, Preliminary results from Groveland/ Riverside ground water study: Pocatello, Idaho Department of Health and Welfare, 25 p.

Stumm, W., and Morgan, J.J., 1981, Aquatic chemistry, an introduction emphasizing chemical equilibria in natural waters (2d ed.): New York, John Wiley and Sons, 780 p.

Talburt, M.S., and Smith, Ora, 1967, Potato processing: Westport, Conn., AVI Publishing Company, Inc., 579 p. 
Thurman, E.M., 1985, Organic geochemistry of natural waters: Dordrecht, The Netherlands, Martinus Nijhoff/ Dr. W. Junk Publishers, 497 p.

U.S. Department of Housing and Urban Development, 1979, Flood insurance study, city of Blackfoot, Idaho, Bingham County: Seattle, Wash., Federal Insurance Administration, $25 \mathrm{p}$.

U.S. Environmental Protection Agency, 1976, Quality criteria for water, 1976: Washington, Government Printing Office, 256 p.

1977, Drinking water and health: Safe Drinking water Committee, pt. 1, chap. 1-5, 581 p.

--- 1982a, Maximum contaminant levels (subpart B of part 141, National interim primary drinking-water regulations): U.S. Code of Federal Regulations, Title 40, parts 100-149, revised as of July 1, 1982, p. 315-318.

--- 1982b, Secondary maximum contaminant levels (section 143.3 of part 143, National secondary drinking-water regulations): U.S. Code of Federal Regulations, Title 40, parts 100-149, revised as of July 1, 1982, p. 374 .

U.S. Geological Survey, 1983, WATSTORE user's guide: Reston, Va., v. 3, chap. VI-A, 26 p.

Vlassoff, L.T., 1977, Klebsiella, in Bacterial indicators/ health hazards associated with water: American Society for Testing and Materials Symposium, Chicago, Ill., 1976: Philadelphia, Pa., American Society for Testing and Materials, Special Technical Publication 635, p. 275-288.

Watson, K.S., Peterson, A.E., and Powel1, R.D., 1977 , Benefits of spreading whey on agricultural land: Journal Water Pollution Control Federation, v. 49, p. 24-35.

Whitehead, R.L., 1974, Chemical and physical data for disposal wells, eastern snake River Plain, Idaho: Idaho Department of Water Resources, Water Information Bulletin $30,31 \mathrm{p}$. 

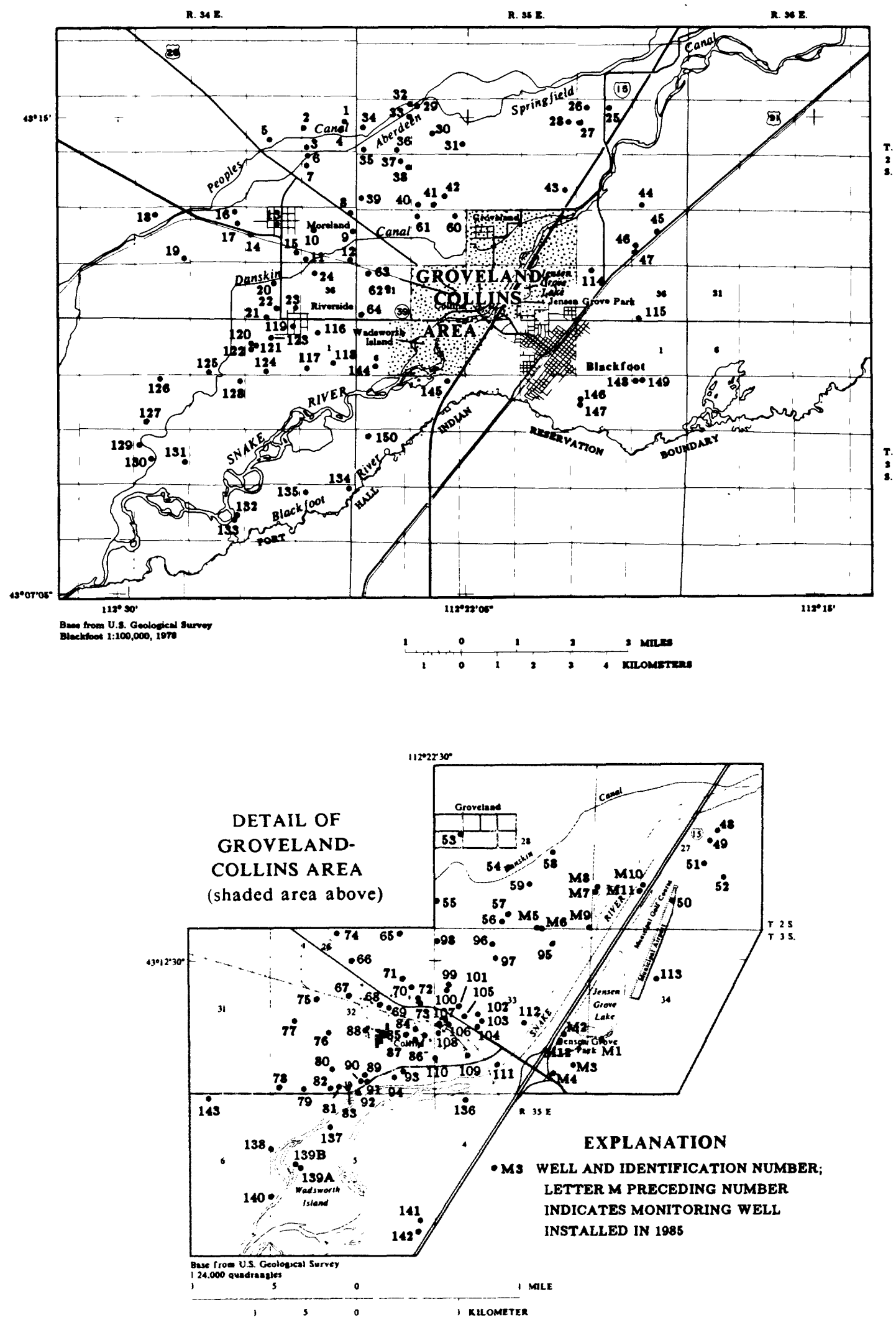

Figure 2.--Location and identification of wells in Groveland-Collins and surrounding areas, 1984-85. 